\title{
The Aesthetics of Dance
}

In Abhinavagupta's famous formulation of aesthetic theory, a dramatic text presented on stage with the help of the spectacular machinery, complete with all of its components, triggers, in the spectator, an experience sui generis that takes the name of rasa. Rasa is the sap, flavour or essence of the performance, and its experience is described as a tasting, relishing or savouring (rasana $\bar{a}$, $\bar{a} s v \bar{a}$ dana, carvana $\bar{a}$ ), drawing on a culinary analogy already in vogue in Bharata's text. ${ }^{1}$ The analysis of the process leading to the arousal of rasa in the spectator and the components into which this process can be dissected form the core of Abhinavagupta's aesthetics. Its essence can be extracted from the extensive commentary dedicated to the famous rasasūtra, Bharata's 'Aphorism on Rasa', vibhāvānubhāvavyabhicārisamyogād rasanișpattih: 'Rasa arises out of the union of the determinants, the consequents, and the transitory states.' ${ }^{2}$ In a scene dominated by śrnigära (the amorous rasa), for example, the determinants (vibhāva) would be all of those factors arousing the character's emotion of delight (rati): a beloved, pleasure gardens, unguents and fragrant creams, garlands, etc. The consequents (anubhāva) would be all the visible reactions to that emotion, such as sidelong glances, gentle speeches, playful movements, and so on. Finally, the transitory states (vyabhicārin) would be those accompanying the primary emotion or stable state (sthāyibhāva), for instance joy, jealousy, shame, etc. Abhinavagupta establishes a fundamental difference between the emotions we experience in ordinary life, the bhāvas, and those that are triggered by a work of art, the rasas. ${ }^{3}$ In theatre, as in literature more generally, the cognizing subject ideally becomes a sensitive spectator, able to savour

1 For a discussion of the culinary analogy and its implications for understanding Bharata's aesthetic theory, see Cuneo 2013.

2 For a translation of the commentary on the rasasütra, see Gnoli 1968; Cuneo 2008-20091; and Pollock 2016. For a partial translation and a broad analysis of Abhinavagupta's aesthetics, see Bansat-Boudon 1992.

3 The primary emotions or stable states (sthāyibhāva) are: delight (rati), humour (hāsa), sorrow (śoka), anger (krodha), valour (utsāha), fear (bhaya), disgust (jugupsā), and astonishment (vismaya) (Nś 6.17, 7.8ff.). Their corresponding rasas are: the amorous (śrngāra), the comic (häsya), the pathetic (karuna), the furious (raudra), the heroic (virra), the fearsome (bhayā$n a k a$ ), the odious (bïbhatsa), and the wondrous (adbhuta) (Nś 6.15, 6.45ff.). Moreover, Abhinavagupta admits a ninth rasa, the pacified (śānta), whose primary emotion is ultimately the àtman itself. On the number of rasas, see Raghavan 1940. 
the emotions depicted through a sympathetic response, which is triggered by the generalization of the emotion. The latter guarantees that the spectator can identify himself with the events depicted and thereby savour the emotions in an essentially blissful experience, i.e. as rasa, an experience devoid of the ordinary reactions to emotions in real life: attachment, rejection, indifference. ${ }^{4}$

Far from developing a mere psychological theory, Abhinavagupta pays great attention to establishing exactly how such 'purified' emotions are engendered through the performance, paving the way for a phenomenological account of the aesthetic experience. If the sixth and seventh chapters of the Abhinavabhärati are mainly concerned with analysing the composition of a work of art in terms of its emotional configuration (the determinants, the consequents, and the transitory and stable states), and how this can trigger an affective response in the spectator, it may be argued that the rest of the commentary strives to integrate all the disparate components of theatre so as to form a coherent and meaningful whole, where all the parts work in harmony, variously contributing to the arousal of rasa. ${ }^{5}$

Once it had been theorized by Bharata as a central principle in the field of dramatics, other theorists - more or less successfully — started to incorporate rasa into the treatment of the different artistic forms, including those having an essentially non-linguistic nature, such as music and dance. ${ }^{6}$ One possible way to explain the incorporation of rasa into other artistic domains has been proposed in the following terms by Katz:

It is natural that music, being treated as part of a Gesamtkunstwerk, such as theatre, should follow the general aims of dramatic and poetic art, namely, it should be able to contain rasa and generate aesthetic responses.

KATZ 1983: 60

4 Although the aesthetic experience is conceptualized as an undivided cognitive event, it can be analysed into a sequence of phases in which the spectator first goes through the 'generalization' of the emotion (sädhäranikarana), implying a process of distancing, since the emotion is felt as common to everybody. This triggers a sympathetic response to the events represented, or empathy (hrdayasamvāada, literally 'dialogue with the heart'), which leads to an identification with them (tanmayībha $v$ va, literally 'the fact of becoming that'), and finally to the savouring or mastication of rasa (rasāsvāda/carvañā). On the different phases of the aesthetic process, see Bansat-Boudon 1992: 152-153.

5 To some extent, however, already in the Nātyaśästra, the various rasas and bhāvas work as organizing principles around which the various dramatic techniques are systematized.

6 In the field of music, such a tendency can already be detected in the Bṛaddeśi of Matanga, a text on music theory written around the eighth century. 
As I will demonstrate in this chapter, instead of treating the incorporation of rasa into the domains of music and dance as a natural development of dramatic theory, Abhinavagupta's analysis is fully aimed at problematizing the presence of rasa in arts other than poetry and theatre, that is, outside of the specialized field of literature.

To understand Abhinavagupta's reluctance to extend the concept of rasa to drama's closest ancillary arts, not to speak of painting and sculpture, one has to keep in mind that his work presupposes a theoretical turn that occurred in Kashmir in the middle of the ninth century, starting in the field of Ālaṃkāraśāstra with Ānandavardhana, and later extending to the adjacent field of Nātyaśāstra. In brief, this paradigm shift consisted in applying a model of textual analysis first developed in the field of Mīmāṃsā- the science of ritual hermeneutics - to the literary work or poetic text. Under the influence of Mìmāmsā, poetics shifted from being dominated by a formalist paradigm, in which single alamkāras are analysed as functioning independently from one another, to a teleological text analysis, in which all the components of the poetic text conspire to bring about the overriding goal of poetry, identified with the ras a principle typically borrowed from the allied discipline of dramatics. ${ }^{7}$ This move entailed a greater focus on the mechanisms of poetic language - the communication of rasa typically being conceived in linguistic terms - as well as a new focus on the epistemology of rasa.

The main conceptual challenges posed by the extension of Mīmāṃsā hermeneutics to poetry and drama are in my view essentially twofold. First of all, if the unity and coherence of the literary work are guaranteed by the rasa principle, and if rasa is conveyed by a specific linguistic function, theorized in Ālaṃkāraśāstra as vyañjanā ('suggestion', 'manifestation') or dhvani ('resonance', 'implicature'), ${ }^{8}$ how can non-linguistic elements such as dance and music, which are typically seen in a dramatic performance, be independently expressive of a rasa or even contribute to its arousal and therefore be meaningfully integrated into a comprehensive theory of aesthetics? In the field of Alaṃkāraśāstra, in fact, the validity of a poetic work can be assessed in terms of poetic suggestion, without exceeding the boundaries of the text and its lin-

7 This paradigm shift has been analysed in McCrea 2008. The new hermeneutics of the poetic text promoted by Ânandavardhana entailed that 'one must always ask not only whether a particular element is beautiful in and of itself, but whether it is appropriate to the aesthetic objective of the work viewed as a whole' (ibid.: 25). To be even more accurate, as argued in Bronner 2016, the active borrowing of cognitive and hermeneutical models from Mīmāṃsā and its transposition within the field of Ālaṃkāraraśāstra had already started with Udbhața.

8 On dhvani, the 'soul of poetry' as theorized by Ānandavardhana, see especially Ingalls et al. 1990 and McCrea 2008. 
guistic matrix. In the domain of Nātyasaāstra, on the contrary, the process of aesthetic communication is much more difficult to account for due to the intrinsic complexity and multimediality of theatre. Apart from a whole array of non-homogeneous artistic techniques, theatre also involves a multiplicity of agents. ${ }^{9}$ Explaining the process leading to the arousal of rasa in the spectator, as epitomized in the famous rasasūtra, became a major ground for dispute in the tradition of dramatics. ${ }^{10}$

The second challenge concerns a development that typically derives from the rapprochement of poetic and dramatic theory. When rasa became the accepted aesthetic standard for both drama and poetry, the attention of the theorists shifted from rasa as aesthetic object to rasa as aesthetic experience."1 This gave rise, in dramatic theory, to a series of new and specific questions, different from those that had first been raised in connection with rasa in the field of literary theory. Theatre, in fact, distinguishes itself from poetry due to its paradigmatic use of dramatic representation or acting (abhinaya) for the communication of rasa. This being the case, how can we account for the communication of rasa in the absence of abhinaya - for instance, in poetry to be heard, danced, or sung - and how can we preserve the specificity of these other art forms, when they incorporate, to a greater or lesser extent, the representational function proper to theatre?

Abhinavagupta's evaluation of the aesthetics of dance can best be grasped in the light of these new theoretical engagements, which developed in Kashmir at a time of intense intellectual and artistic renewal. In such a climate of cultural effervescence, the newly developed theories could immediately be tested against the existing practices and vice versa. Rather than being simply considered as infused with rasa, or as capable of directly conveying rasa, the object called nrtta ('dance', in its many acceptations) was examined both in connection with its ability to work within the theatrical performance-seen as an interconnected whole - as well as independently, as a form in its own right, distinct from theatre but sharing many of its features. Under these premises,

9 On the new challenge posed by the analysis of the spectacular object from the hermeneutic perspective elaborated by Mīmāṃsā, see Ganser 2016.

10 In particular, the shift of rasa from the character (or the actor) to the spectator (the perceiving subject), in the revolutionary work of the tenth-century literary critic Bhatta Nāyaka, raised compelling new questions about its creation from factors belonging to the dramatic text and its performance.

11 This is just one of the possible ways to explain the semantic shift of the word rasa from its first occurrence in the field of aesthetics in Bharata's treatise to its reconceptualization by Abhinavagupta. On the crucial question of the interpretations of the word rasa before Abhinavagupta, see Pollock 1998, 2016; Ali 20o6; and Cuneo 2013. 
the question dealt with in the section of the Abhinavabhärati edited and translated in this book could be put in the following terms: provided that dance is a component of theatre, are we justified in attributing to it an active role in the aesthetic process culminating in the rasa experience, or should we consider it a simple embellishment to the performance, the way in which Ālaṃkārikas conceived ornaments and poetic qualities prior to the Kashmirian poetic revolution? And if dance be taken as an independent form of spectacle, connected with a poetic text endowed with rasa, does it remain an ornamental art of bodily movement, or does it assume a theatrical nature? Before proceeding to the exposition of Abhinavagupta's detailed and original examination of these connected issues, it will be useful first to have a look at the prodromes of a discussion about dance in Bharata's text.

\subsection{Dance within Theatre, Dance without Theatre}

To begin with, an enquiry about the place of dance in Bharata's theatre is called for by the very narrative logic built up in the Nätyaśāstra. Even though, in the economy of the treatise, dance is treated earlier than all the other elements of performance, from the temporal perspective of the narrated events, it represents a further addition to an already complete entity, the knowledge of which it presupposes. ${ }^{12}$

The questions about the reason for introducing dance into theatre are presented in the Nātyaśästra as if they were asked, out of sheer curiosity, by the Rșis gathered around Bharata to hear about the origin of theatre. The questions arise, namely, after Bharata's account of how Śiva presented the gift of dance to Tandu, and he in turn connected dance with melodic and instrumental music, thus giving shape to the tändava. This episode recounts the first formal transmission of the art of dancing directly from the deity to an apt recipient. Whether we place it in illo tempore or just before the transmission of the art of dance from Taṇu to Bharata, chronologically it necessarily precedes Bharata's systematic description of the karanas and angahäras to the Rṣis, although it follows in the textual economy of the treatise. The account of the pindibandhas and their foundation myth and of how Tandu connected dance with music are also presupposed by the seers' questions about dance. Their background could be reconstructed as follows: Siva advises Brahmā to introduce

12 On the first introduction of dance into theatre via the kaisiki $v r t t i$, and on its further introduction by Śiva into the preliminary rite, through its formal teaching by Tanḍu, see $§ 1.3 \cdot 3$. 
dance into the pürvarainga; he calls Tandu and tells him to instruct Bharata in dance; Siva transmits the dance to Tanḍu; Tanḍu connects dance with instrumentation; and Bharata is instructed by Taṇu in the karanas, angahāras, and recakas. Having listened to all this, the Ṛșis pronounce two crucial verses:

Given that dramatic acting has been devised by those experts in [theatre] for the sake of attaining [its] objects, why indeed has this dance been devised [and] what is the nature to which it conforms? It is not connected with the contents of the songs, nor does it bring any object into being. Why has this dance been devised in [connection with] gïtas and āsāritas? ${ }^{13}$

It is not easy to evaluate the exact purport of this sentence in Bharata's order of ideas. Surely, the second part of the question has to be related to the sphere of the purvaranga, since it mentions some of the technical terms proper to it. Siva, in fact, suggested making the preliminaries variegated by introducing dance into the vardhamāna, the gìtakas, and the āsāritas, as well as by enacting the meaning of the mahägitas. ${ }^{14}$ The details on the course of action followed in combining dance with songs and instrumental music in the pürvaranga are provided immediately after the answers to the questions of the Rṣis (v. 4.269cd$27 \mathrm{Oab} \mathrm{ff}$.). In the various segments forming the longer musical compositions of the preliminary rite, the phases of abstract dance $(n r t t a)$, performed to instrumental music, alternate with moments of enactment (abhinaya), aimed at representing the meaning of the song lyrics. This alternation is particularly visible in the vardhamāna, a musical piece comprised of a collection of four āsāritas, and in the gitakas, a fixed group of seven musical compositions, starting with the madraka, that are performed as the first limb of the pürvaranga after the drawing of the curtain. ${ }^{15}$ The actual presence of dance side by side with acting in these musical structures suggests two different but contiguous uses of bodily movement. Moreover, Śiva's instruction to use dance to enact the meanings of 'great songs' makes the function of dance overlap with that of abhinaya, which might have raised legitimate doubts about their respective domains and separate identity. ${ }^{16}$

13 Nś 4.261cd-263ab: yadā prāptyartham arthānām tajjñair abhinayah krtah \|| kasmān nrttam krtaṃ hy etat kam svabhāvam apekșate | na gìtakārthasaṃbaddham na cāpy arthasya bhāvakam || kasmān nrittaṃ krtam hy etad gīteșv āsāriteșu ca |

14 Nś 4.14-15ab, cf. §1.3.3, n. 75 .

15 On the structure of the pürvarainga, see $\S 2.3 .2, \mathrm{n}$. 91.

16 Transposed to the terminology nowadays used by scholars of performance, this could be 
Alternatively, the first part of the question 'why indeed has this dance been devised and what is the nature to which it conforms?' can be viewed as a more general question concerning the nature and scope of the newly introduced object called 'dance' within theatre. As told in the narrative of origins, dance assumed the status of an ancillary of theatre only after adding the kaisiki vrtti to the other manners. In this connection dance is declared to be a constituent element of the bodily acting (ängikäbhinaya), along with two other modes of using the body expressively, namely śäkha and ankura. ${ }^{17}$ This suggests that dance must have played a role in the protocol of acting, at least as a mode of bodily expression, if not as directly connected with representational content. As can be gleaned from some famous specimens of classical Sanskrit plays, dance could also function as the content of representation itself: dance scenes indeed became a favourite topic of depiction by dramatists. ${ }^{18}$

The laconic answer, provided by Bharata in three verses, does not help us any further in narrowing the scope of the questions posed by the seers:

On this point, it is said that dance does not indeed conform to any object, but it is meant to generate beauty (śobhā); that is why dance has come into use. Generally, everybody likes dance in itself. Moreover, this dance is praised because it is considered auspicious (mangalya). And on [occasions such as] weddings, the birth of a child, welcoming a new child-inlaw, jubilation, success, and so forth, it is a cause of merriment. That is why this dance has come into use. ${ }^{19}$

regarded as a problem of the fuzzy boundaries between the phenomenal body and the semiotic body, i.e. the body perceived in itself, i.e. in its own materiality, and the body perceived as something else, i.e. as a signifier. On these two concepts, see Fischer-Lichte 2008: 140-147, and for their application to ancient dance discourse, see Schlapbach 2018: 10.

17 The relevant verse is Nś 8.14: asya śäkhā ca nrttam ca tathaivāinkura eva ca | vastūny abhinayasyeha vijñeyāni prayoktrbhih || 'The śăkhā, dance and the ankura are known as the elements of this [bodily] acting.' Abhinavagupta quotes this verse on several occasions, on which see below, n. 182 .

18 A famous example is the dance competition described in the Mālavikägnimitra. This and other examples could be regarded as cases of ekphrasis, to borrow a term from classical studies. For a discussion of the importance of ekphrasis in the study of ancient dance, in the less commonly attested sense of 'literary depictions of dance', see Schlapbach 2018: 9-18.

19 NŚ 4.263cd-266ab: atrocyate na khalv artham kañcin nṛttam apekșate || kin tu śobhām prajanayed iti nrttam pravartitam | prāyeṇa sarvalokasya nrttam iștam svabhāvatah || mangalyam iti krtvā ca ṇ̂ttam etat prakìrtitam | vivāhaprasavāvāhapramodābhyudayādișu || vinodakāraṇam ceti ṇttam etat pravartitam | 
A straightforward translation of the term śobhā as 'beauty' may sound reductive and not unambiguous, considering that the concept of beauty in art and aesthetic theory has had such a multiplicity of interpretations in the West. ${ }^{20}$ The task proves even more arduous when one considers that a fully fledged theory of aesthetics, which might be of help in evaluating these statements on dance, is nowhere to be found in Bharata's text. In other parts of the Nätyaśāstra, the term sobhā is connected with the idea of beauty as achieved through ornamentation, that is, through the addition of some beautifying element. Similarly, in the chapter on harmonious acting (sāmānyābhinaya), śobhā is listed among the seven effortless (ayatnaja) graces or virtues (lit. 'ornaments', alamkāras) of women, ${ }^{21}$ and is explained as the action of embellishing (alamkaraña) the limbs with physical beauty (rüpa), youth (yauvana), and charm (lāvanya), enhanced by amorous enjoyment. ${ }^{22}$ When, on the contrary, śobha is manifested as one of the virtues of the hero, it consists in the display of resolve (dhairya), prowess (śaurya), valour (utsäha), and contempt for menial objects, a quality in which he vies with the best of men. ${ }^{23}$ Elsewhere in the Nătyaśāstra, śobhā is described as something produced through the addition of some element to an already complete whole, as for instance by adding facial colouring (mukharāga) — e.g., blushing — to an already well constructed bodily enactment, complete with the major and minor limbs. Indeed, although bodily acting might be less prominent at some moments in the dramatic performance, when one employs facial colouring, beauty is nevertheless doubled, like the night by the moon. ${ }^{24}$

20 An informed history of beauty in the Indian context still needs to be written. For the various words used for indicating 'beauty' or beauty-related concepts in the field of Sanskrit poetry, see Ingalls 1962 and Smith 2010. A significant step in the interpretation of the concept of beauty in a broader cultural perspective was taken by Ali in his innovative study on courtly culture. Ali (2004: 143) speaks of 'an enduring concern with beauty' and suggests that 'the theory of beauty was something like a worldview'. On beauty in the Indic world, see also Raghavan 2008 and the recent Torella (forthcoming) on spiritual and aesthetic beauty in Abhinavagupta's work.

21 The other types of graces are the three produced from the body (argaja) and the ten natural ones (svābhāvika). Cf. Nś 22.5 and, for a study thereof, see Bansat-Boudon 1991a, where these graces are given the collective name of sättvikälamkāras. Nś 22.27: rūpayauvanalāvanyair upabhogopabṛ̣hitaih | alaṃkaraṇam añgānām śobheti parikirtitā $\|$

23 Nś 22.34: dākṣyam śauryam athotsāho nīcārtheșu jugupsanam | uttamaiś ca guṇaị̣ spardhā yatah śobheti sā smṛtā\|

24 Nś 8.165cd-167ab: śākhāngopāngasamyuktaḥ krto 'py abhinayaḥ śubhaḥ \| mukharāgavihīnas tu naiva śobhānvito bhavet | śärīrābhinayo 'lpo 'pimukharāgasamanvitaḥ|| dvigunāạm labhate śobhām rātrāviva niśākaraḥ| 
With regard to the use of bodily movement, the production of beauty in the body in both theatre and dance is said to depend on a certain grace of the limbs, called sausțava. ${ }^{25}$ In all these occurrences, śobha coincides to some extent with the production of a specific kind of beauty in an already beautiful aggregate, through the addition of a special element enhancing it. Is dance used similarly in theatre, as an embellishment that guarantees the production of beauty? And how does beauty contribute to the performance and its overall aim? As a matter of fact, no clear idea about the supposed aesthetic function of dance can be traced in the fourth chapter of the Nätyaśāstra, nor is it possible to draw a definite picture of the place of dance within the performance of a play. ${ }^{26}$

As to Bharata's qualification of dance as auspicious (marigalya), it should be pointed out that this term has to be seen in connection with the festive occasions to which dance is linked outside of theatre. Apart from dance, instrumental music is also prescribed by Bharata for the depiction of auspicious occasions in a play, suggesting the analogous use of music independently of theatre. ${ }^{27}$ Situations in which dance and music are used in connection with festivals and rituals find depiction in the extant plays and in literature more generally. ${ }^{28}$ All this suggests that the use of dance and music for auspicious ends had its basis in worldly practices.

25 Nś 10.89cd-91ab: saușțhave hi prayatnas tu kāryo vyāyāmavedibhịh || saușțavam lakṣaṇam proktam vartanākramayojitam | śobhā sarvaiva nityam hi saușthavaṃ samupāśritā || na hi saușțavahīnāngaḥ śobhate nātyanrttayoḥ| On saușthava and its connection with dance, see $\S 2.2$, n. 62 .

26 Besides the intrinsic difficulties in reconstructing scenic practices that are no longer extant, the written medium - be it in the form of theoretical manuals or of dramatic texts-is in any case inadequate to account for a living reality such as dance. Although art forms like Kutiyattam and Kathakali are generally considered the closest 'heirs' of classical Sanskrit drama, the data we receive from modern sources should be handled with care. There has been a tendency among scholars, especially in the pioneering studies on Indian theatre, to superimpose what one sees on stage today onto the ancient theatre outlined by Bharata, so that a 'dance character', similar to that witnessed in contemporary performances of Bharatanatyam and Odissi, has been unjustifiably superimposed onto Sanskrit theatre. On the political motives underlying such over-interpretations, see §1.2.

27 Cf. Nś 34.18-19: utsave caiva yāne ca nṛpāṇām mañgaleșu ca | śubhakalyānayoge ca vivāhakaraṇe tathā || utpāte saṃbhrame caiva sañgrāme putrajanmani | ìdrśseșu hi kāryeșu sarvātodyāni vādayet || Note that Abhinavagupta affirms that musical instruments should be played all together on such occasions, both in theatre and in the world (ABh ad locum, vol. 4, p. 413: etac ca nattye loke 'pi ca). The reference here is probably to the dramatic depiction of festivals, which is based on the world.

28 See, for instance, the description of the dance performed ritually in the temple of Mahākāla in Ujjain in Kālidāsa's Meghadūta (vv. 34-36), or the depiction of Kāma's festival in the first act of Śrī Harṣa's Ratnāvalī. 
Taking advantage of the intrinsic ambiguity of Bharata's statements, Abhinavagupta unsheathes his exegetical weapons and literally dismantles the questions about dance, starting from the very source of the query. Disregarding the caption 'the seers said' (rșaya ücuh) which, in the transmitted text of the Nātyaśāstra, precedes the questions about dance, Abhinavagupta interprets the two verses as an imaginary objection ( pürvapakșa), raised by Bharata himself in the guise of an opponent. ${ }^{29}$ Hidden under such a guise, the opponent/Bharata would raise the following doubt:

Is dance different from theatre or is it no different from it? And if it were considered to be different, would it have a purpose or not? ${ }^{30}$

In the typical style of a philosophical debate, the presentation of the opponent's view or first thesis ( pürvapakșa) is followed by a long elaboration, in which the positions of various adversaries are exposed and refuted before the established opinion (siddhānta) is finally presented in the form of an answer to the pürvapakșa (Nś 4.263cd-266ab). Two main opponents alternatively take the floor, through objections and counter-objections: the first maintains the identity of dance and theatre, and is thus called 'abhedapakșin'; the second argues in favour of their difference, whence the appellation 'bhedapakșin'. The arguments of the abhedapakșin, identified with the pürvapakșa staged by Bharata, will form the main object of Abhinavagupta's refutation. Although the commentator upholds the difference between dance and theatre, the arguments of the bhedapakșin may be regarded as a prima facie view, lacking as they are in proper philosophical acumen. They mainly serve the purpose of moving the debate forward and bringing its different levels of interpretation to the fore. The pürvapakșa is in fact presented as tripartite, on the basis of three different alternative interpretations of the purport of Bharata's questions, which are derived by playing on the polysemy of the Sanskrit words in Nś 4.261cd-263ab.

Thanks to this sophisticated device, the pürvapakșa reveals a multiplicity of layers in which the word ' $n r t t a$ ' is seen to refer, successively, to 1) dance as an independent genre of staged performance; 2) dance as an element of the dramatic performance or play; 3) dance as a component of the pürvaranga. Accordingly, questions about the nature of dance and its difference from theatre apply to all three domains. In all the three cases, the pürvapakșin

29 See Translation 1.1.

$30 \quad$ ABh ad Nś 4.261cd-263ab, vol. 1, p. 168: nrtttam nātyād bhinnam abhinnaṃ vā. bhinnatve 'pi saprayojanam aprayojanam $v \bar{a}$. 
assumes the presence of a fundamental feature of theatre in dance, namely its mimetic or narrative function, called abhinaya, which would be the ground for their assimilation. Even though the thesis that dance and theatre are the same will ultimately be refuted, this does not entail the complete denial of abhinaya in dance. The position that dance is a bodily movement devoid of abhinaya, which corresponds to the communis opinio expressed, for instance, by Dhanika, is presented by Abhinava only as a temporary position in his unprecedented examination of the nature and aesthetics of dance. ${ }^{31}$

In my opinion, Abhinavagupta's original argument aims at enlarging the field of dance so as also to encompass the emerging new spectacular genres, such as Dombikā and others, which the texts list under a variety of categories: nrttakārya, nrtya, uparüpaka, and the like. ${ }^{32}$ These genres patently contain some form of enactment, just like the lāsyānga dance pieces of the pürvarañga, since both connect dance with the lyrics of the songs to which they are performed. Moreover, in the case of the other songs in the preliminary rite, it is not the alternation of dance and dramatic acting that raises ambiguity about the respective spheres of application of dance and theatre, but rather the fact that dance itself is used to enact textual meaning, that is, as an abhinaya.

First of all, Abhinavagupta's definition of $n r t t a$ has to be flexible enough to encompass all the different manifestations of dance. Secondly, in order to avoid its conflation with theatre due to their common use of enactment, Abhinavagupta opts for an overall reconfiguration of the meaning of abhinaya in theatre and dance. Moreover, just as abhinaya enters the sphere of dance,

31 See Translation, 3.1. On this point, my interpretation of Abhinavagupta's ultimate position differs from that of Bansat-Boudon, who declares: 'Du débat, nous ne donnerons que les conclusions: la danse, en effet, diffère du théâtre en ce qu' elle est exempte d'abhinaya' (Bansat-Boudon 1992: 400). The definition of dance as a movement of limbs devoid of representational function, however, is the most common by far in the theoretical texts. It appears for the first time in the Avaloka on the Daśarūpaka, where Dhanika interprets the definition of dance as tālalayāśraya- (DR 1.9b) as tanmātrāpekșo 'ñgavikșepo 'bhinayaśūnyo nrttam iti (AL ad DR 1.9), cf. § 2.1, n. 24. The Sampītaratnākara of Śārngadeva (13th c.), which otherwise follows the Abhinavabhäratī quite closely, presents the same tripartite object as the Daśarūpaka and defines dance in analogous terms: gātravikșepamātram tu sarvābhinayavarjitam || ängikoktaprakārena nrttam nṛttavido viduh | (sR 7.27cd-28ab) 'The experts in dance, however, know dance as consisting in a mere throwing of limbs, devoid of all kind of enactment, under the modality that has been stated with regard to bodily acting.'

32 The possibility that Abhinavagupta could have deliberately avoided using the category of nrtya, common in other texts, has been discussed in $\S 2.1$. On the scope of the word $n r t t a$ in the Abhinavabhäratī and on the seven nrtta varieties, see $\S 2.4$ and Translation 8.6. 
dance is seen to participate in theatrical performance, not only in its preliminary phase, but both as a topic in the narrative plot and as a staging technique. In the latter respect, dance is considered, though in a very special sense, to be part of the bodily code used to express emotions and ideas, the socalled āngikäbhinaya. This raises questions about its potential as an expressive medium within drama. Similar questions about expressivity are raised in connection with other non-linguistic elements of theatre, such as instrumental music and vocal singing. Their overwhelming presence during a theatrical performance is suggested by the orchestra being placed directly on stage, as well as by the many instances of songs and instrumental accompaniment punctuating key moments in the dramatic representation, for instance the entrance of characters, sudden changes or transitions in the emotive mood, and so on. The issue of the connection of dance and music might thus be seen to develop from a specific question about the use of bodily movements along with āsāritas and other songs in the pürvaranga, to a more general query about the coordination of the different elements in the staging of a play. The presence of dance and music within the play calls moreover for a consideration of the role of pleasure and the alluring elements in the aesthetic process, and the contribution of beauty to the attainment of the twofold aim of theatre, i.e. pleasure (priti) and instruction (vyutpatti), both encompassed by the notion of rasa. ${ }^{33}$

Without recounting the whole discussion of the nature of dance and its difference from theatre - which can be consulted in the edition, translation, and explanatory notes presented in this book-in the rest of this chapter I will concentrate on the original motives of what I regard as Abhinavagupta's formulation of an 'aesthetics of dance'. Before we delve into the question of the role of dance as an expressive medium within theatre, we must have a look at its homologue, dramatic acting, and its categories.

\subsection{Enacting Emotions: A vademecum for the Actor}

Si deve trovare un linguaggio-con parole, con immagini, movimenti, atmosfere-che faccia intuire qualcosa che esiste in noi da sempre. È una conoscenza molto precisa. I nostri sentimenti, quelli di tutti noi, sono molto precisi. ${ }^{34}$

PINA BAUSCH

33 On pleasure and instruction as the twofold purpose of theatre, see below, § 3.4 .

34 From Laurea Honoris Causa a Pina Bausch, Alma Mater Studiorium, Università degli Studi 
Dramatic acting (abhinaya) has been recognized in India as the characteristic feature distinguishing drama from other literary works. The earliest theoreticians of poetry had already posited a disciplinary boundary between drama and poetry on the basis of the enactment of the literary content in the former. ${ }^{35}$ The amplitude of the treatment devoted to this defining feature of drama in Bharata's text finds no parallel in other dramatic traditions across the world. The techniques of enactment in fact cover the entire scope of an actor's activity, including his capacity for control over the emotional sphere. Judging from the extent of the treatment of bodily movement in the Nātyaśästra, and as can also be gleaned from contemporary dance/theatre practices, it appears that the Indian tradition never considered gesticulation as a mere appendix to the written text. On the contrary, body language or non-verbal behaviour was viewed as a fully fledged expressive medium, whose techniques could be codified through rules and mastered by actors.

The four registers of acting are the bodily (ängika), the vocal ( $v \bar{a} c i k a)$, the psychophysical (sāttvika), and the ornamental (āhärya). ${ }^{36}$ These are, as their names indicate, differentiated according to the medium by which the representation is carried out: the body, the voice, the mind, and the costume. From the most general uses down to the smallest details, dramatic acting was seen as closely intertwined with the emotional sphere, including in its textual encoding. ${ }^{37}$ The general definition of abhinaya is given in Nś 8.6, based on its etymological formation:

The root $n \bar{l}$, preceded by [the prefix] abhi-, has the sense of determining the meanings (artha) [of the dramatic text] as directly manifested in front (äbhimukhya) [of the spectator]. It is called abhinaya because it carries

di Bologna, 1999, quoted in Lo Iacono 2007:129. ('One should find a language—with words, images, movements, atmospheres — capable of suggesting something that exists within us since time immemorial. This knowledge is very precise. Our emotions, those of everybody, are very precise' [my translation]).

35 See, for instance, Bhāmaha's Kāvyālaṃkāra 1.24cd on drama (nāțaka): uktaṃ tad abhineyārtham ukto 'nyais tasya vistarah || 'Drama has been said to have its content enacted, and its details have been expounded by others.'

36 Cf. Nś 6.23: āngiko vācikaś caiva hy āhāryah sāttvikas tatha | cātvaro 'bhinayā hy ete vijñeyā nātyasamśrayāh || For an elaboration of the term 'abhinaya' with respect to the means involved, as opposed to the restricted Western concept of 'acting' or 'reciting', see Ganser 2007: 65-67. This section represents a revised and enlarged version of this earlier article.

For instance, of the thirty-six types of looks (drștiis) that are classified in Nś 8.40-44 as part of the upāngäbhinaya ('acting through the minor limbs'), eight correspond, by a rather artificial parallelism, to the eight rasas, eight to the eight sthāyibhāvas, and the remaining twenty to some of the vyabhicāribhāvas. 
(nayati) the objects (padārtha) [of theatre to the audience]. And it has been called abhinaya since it determines the different meanings, according to practice, in association with the twig-limbs $(s \bar{a} k h \bar{a})$, the major limbs (anga), and the minor limbs (upānga). ${ }^{38}$

Dramatic acting is thus defined according to its function in theatre, which is to communicate the textual meanings to the audience. These meanings are primarily conceived in terms of emotions, as it emerges, for instance, from the use of the term abhinaya in what Abhinavagupta regards as the very definition of theatre: 'This nature proper to the ordinary experience, associated with pleasure and pain, is called theatre (nātya) when it is conveyed by the means of dramatic enactment such as the bodily and the others (arigädyabhinaya). ${ }^{39} \mathrm{An}$ even more specific link between acting and the emotional sphere is provided in the definitions of the bhāvas in the seventh chapter: 'the emotional states (bhāva) [are so called, since] they, associated with the voice, the body and the mind (sattva), bring the contents of poetry (kāryārtha) into being (bhāvayanti): ${ }^{40}$

The treatment of acting techniques covers the largest portion of Bharata's treatise (roughly chapters 8-26). The commentary on the eighth chapter, on bodily acting (ängikäbhinaya), is lost at present, and there is little hope that it will ever resurface. This is all the more regrettable since the eighth chapter is the first in the treatise to deal exclusively with the topic of abhinaya, and therefore must have contained important introductory remarks on the art of acting in general, and through the body in particular. ${ }^{41} \mathrm{I}$ deem it legitimate

38 NŚ 8.6-7: abhipūrvas tu ṇīndhātur ābhimukhyārthanirnaye | yasmāt padārthān nayati tasmāt abhinayah smrtaḥ || vibhāvayati yasmāc ca nānārthān hi prayogatah | śākhāngopāngasamyuktas tasmād abhinayah smṛtah || In Nś 8.6c, some manuscripts read yasmāt prayogam nayati; however, given Abhinavagupta's insistence elsewhere on the fact that abhinaya carries the meanings, I prefer to read padārthān here.

39 Nś 1.119: yo 'yam svabhāvo lokasya sukhaduhkhasamanvitah | so 'ngādyabhinayopeto nātyam ity abhidhīyate \|

$40 \quad$ Nś prose before 7.1: vāgañgasattvopetān kāryārthān bhāvayantīti bhāvā iti | According to Abhinavagupta, the kāryārthas are the rasas, whose savouring is preceded by the knowledge of the stable and transitory states (cf. ABh ad locum, vol. 1, p. 337).

41 It might be argued that the first chapter dealing with abhinaya should be considered the one on the emotional states (bhävas), namely the seventh chapter, since it is here that the psychophysical states (sāttvikabhāvas), which are part of psychophysical acting (sāttvikābhinaya), are explained at length. (See Nś 7.93-117, as well as Nś 8.10: sāttvikah pūrvam uktas tu bhāvaiś ca sahito mayā | añgābhinayam evādau gadato me nibodhata || 'The psychophysical-[acting] has been treated by me earlier [in the treatise], in connection with the bhāvas. Now listen to the explanation of the bodily acting'). The commentary on the seventh chapter, however, breaks off abruptly after the fourth verse. 
to assume that something of a fully fledged theory of acting may have been presented in this lost chapter of the Abhinavabhäratī, since Abhinavagupta declares on various occasions that he will later engage in explaining some particular aspect of abhinaya that one cannot trace to the extant portion of the commentary. ${ }^{42}$ Even though it is not possible, given the present state of the text, to form a complete picture of Abhinavagupta's concept of dramatic acting, occasions for speculation about such a central topic are not lacking throughout the extant text of the Abhinavabhäratī. In this perspective, the discussion about dance and abhinaya dealt with in the Tāndavādhyāya and fully translated here assumes a new relevance for the study of Abhinavagupta's 'lost theory of acting'.

As to the group of four abhinayas, these are sometimes referred to with the abbreviated formula āngikädyabhinaya-, or angādyabhinaya-, which refers in

42 For instance, the anticipation of the full explanation of the śākhā in ABh ad Nś 4.61cd$62 \mathrm{ab}$, on which see $\S 2.2, \mathrm{n}$. 45. Other examples include mentions of topics to be discussed in the chapter on upāngābhinaya, suggesting that a full account of abhinaya and its various means was to be found there. For instance: ABh ad Nś 14.2, vol. 2, pp. 220-221: eșa hi tanur nātyasya sakalaprayogabhittibhütatvenātodyagïtäbhinayānugrāhakatvāt svayam abhinayarūpatvāe ca. pradarśitam caitad asmābhir upāngābhinayārambha eva. 'For this [i.e. the voice] is the body of theatre since, due to its being the canvas on which the whole performance [is inscribed], it encompasses instrumental music, singing and acting, and since it itself has the nature of enactment [i.e. the vācikäbhinaya]. We have shown this at the beginning of the [chapter on the] acting through the minor limbs (i.e. Nś ch. 8)'; ABh ad Nś 22.1, vol. 3, p. 149: vāgañgasattvābhinayā anyonyam sahacaryamāṇāh, na tv evaṃ teșv āhārya ity asyānupādānakriyā. etac ca na muner matam ity āveditam asmābhir upāngābhinayāhāryābhinayādhyāyayor ity āstām, "The registers of acting through the voice, the body and the mind sustain each other, but the one based on the costume does not [interact] with them in the same way. That is why it has not been included [in the sāmannyäbhinaya]. But this is not the opinion of the Muni, as we have acknowledged in the chapter on acting through the minor limbs (i.e. Nś ch. 8) and in the one about ornamental acting. Let the matter rest for the time being'; ABh ad Nś 22.50, vol. 3, p. 174: yat pūrvam uktam-asya śākhā ca [corr., na $\mathrm{E}_{1}$ ] nrttam ca tathaivāñikura eva ca | trividham vastv abhinayasya [corr. Bansat-Boudon 1992: 387, n. 466a, abhinayah ... $\left.\mathrm{E}_{1}\right] \mid$ iti tena sahāsya yathā na virodhas tathaivopapāditam upāngābhinaye. 'As to what has been stated before[, namely that] "the śäkhä, dance (nrtta), and the aikura are the three elements of the [bodily] acting (abhinaya)" (Nś 8.14), it has been demonstrated in the chapter on enactment through the minor limbs how it does not contradict the [reasoning here]' (For the context of this statement, see Bansat-Boudon 1992: 387); ABh ad NŚ 22.51, vol. 3, p. 175: kevalaṃ tatkālikātatkālikādimātreṇa vākyam bhidyatāṃ nāma. etac copāngäbhinaye vitatyopapāditam. 'It is possible to disjoin the sentence [from the enactment] only insofar as it may be simultaneous or non-simultaneous with it. Moreover, we have treated this [topic] in detail in the [chapter] on acting through the minor limbs.' 
order to bodily, ${ }^{43}$ vocal, ${ }^{44}$ psychophysical, ${ }^{45}$ and ornamental acting. ${ }^{46}$ The hierarchy between them is explained by Abhinavagupta in metaphorical terms: while vocal enactment is the body of theatre (tanur nätyasya), since it is like a canvas on which the whole performance is inscribed (sakalaprayogabhitti), bodily enactment provides theatre with vital breath (nātyānuprānaka) $\cdot{ }^{47}$ Still superior to these is psychophysical enactment, in which theatre is grounded (cf. Nś 22.1cd: nätyam sattve pratișthitam), and according to the presence of which a performance can be defined as superior, average, or inferior. ${ }^{48}$ As to costume or accoutrements (ähärya), its very status as an enactment was a debated topic among theoreticians since, strictly speaking, costumes and scenic props are not acting techniques. Nevertheless, as Abhinavagupta argues, actors use them in order to hide their own identity beneath that of the dramatis persona, hence they help in conveying the determinant factors to the spectators, which is one of the functions specific to abhinaya. ${ }^{49}$

43 Ärgikäbhinaya covers Nś chs. 8-12 and is said to be threefold: corporal, facial, and based on gestures (Nś 8.11: trividhas tv ängiko jñeyah śärīro mukhajas tathā| tathā ceștākrtaś caiva śäkhāngopāngasamyutah $\|)$. Although facial expression (mukhaja) is explained in chapter 8 and is based on the minor limbs (upāinga), the scope of the other two subdivisions, i.e. śārīra and ceștākrta, and how they differ from one another is not crystal clear. On the range of the major and minor limbs, see Nś 8.13 (cf. § 2.2, n. 39).

44 Vācikābhinaya does not concern prosody alone, but the written text as well, so that along with instructions on prosody —including intonation, accentuation, pauses, and so forthdirections are given to the poets on how to write a play using the appropriate plot, metres, rhetorical figures, and language. See below, n. 111 .

45 The principal object of sāttvikäbhinaya are the emotions, in which both a psychical and a physical dimension is recognized, hence the English rendering as 'psychophysical acting'. No specific chapter of the Nätyaśāstra is devoted exclusively to this means of enactment, and no acting technique can be actually apprehended and systematized under this heading. Nevertheless, Abhinavagupta (ABh ad Nś 1.23, vol. 1, p. 17) refers to some technique connected with breath control ( prāna) that the actor could use to display on his body the signs of an intensely felt emotion, the so-called sāttvikabhāvas, listed as paralysis (stambha), perspiration (sveda), horripilation (romãñca), stammering (svarabheda), tremor (vepathu), change of colour (vaivarnyya), tears (aśru), and fainting (pralaya) ( $\mathrm{Ns}$ 7.94). On sāttvikäbhinaya, see Bansat-Boudon 1991a, 1992; Malinar 2010; and Cuneo \& Ganser (forthcoming).

46 The section on āhäryābhinaya, in Nś chapter 21, describes the dress and the make-up along with a reduced number of accessories, such as bows and banners, and scenic devices like props.

47 Cf. ABh ad Nś 14.1-2, vol. 2, p. 220: nātyānuprānakatayā pürvoddișțāngikasya, and n. 42 above.

48 Cf. Nś 22.2, in Translation, n. 34.

49 On the various arguments for and against the exclusion of āharrya from the discussion on sāmānyābhinaya, see ABh ad Nś 22.1, translated in Bansat-Boudon 1992: 363-364. 
In order to bring out the emotional core of theatre, the four abhinayas need to be used in combination. With a view towards their effective employment by actors and theatre directors, the technique of acting is analysed into a harmonious acting' (sāmānyābhinaya) and a 'pictorial acting' (citrābhinaya), the objects of chapters 22 and 25 respectively. As pointed out by Bansat-Boudon, such a twofold division into basic and combined techniques has to do with the field of theatrical practice, not textual structure:

Whereas the abhinaya, when it is presented as quadruple, consists of an inventory of elementary techniques of acting, the sāmānyābhinaya and the citrābhinaya actually represent the same techniques put into practice on stage by the actor in the specific context of performance according to rigorously codified procedures. Therefore, a new statement whereby the actor will initiate himself to these rules of interpretation unknown to him as yet proves necessary. This accounts for the double treatment given to abhinaya in the Nātyaśāstra.

BANSAT-BOUDON 1995: 150

The sāmānyābhinaya is explained by Abhinavagupta through the metaphor of the perfumer who, combining the different essences and basic substances in the right quantities, skilfully creates a fragrant, homogeneous blend. ${ }^{50}$ The section on sāmānyābhinaya focuses on the enactment of the inner states, giving ample scope to the unfolding of love between men and women, while that on citräbhinaya describes the enactment of the various external realities. ${ }^{51}$ According to Abhinavagupta, both methods of acting are ultimately concerned with the communication of emotional meaning. The sāmānyābhinaya is a mingling of the means of dramatic enactment for the sake of conveying the objects in which rasa is predominant (rasātmakapradhānam padārthaviśeșam abhinayānām samān̄îkarañam, ABh ad Nś 25.1, vol. 3 p. 264), while the citrābhinaya is conceived as a subtype of it, a blend specialized in the depiction of the external objects, useful for bringing the rasa and the other emotional states into being (rasādyupayogibāhyavastuvișayam evābhinayānāṃ bhāvanārūpam miśrīkaraṇātmakam samānīkaraṇam, ABh ad Nś 24.9o, vol. 3, p. 263).

50 On the image of the perfumer in the Abhinavabhäratī and a translation thereof, see Bansat-Boudon 1989-199o: 68, 1992: 344, and 2004: 158-176.

51 As Bansat-Boudon (1995: 150) states it, 'the citräbhinaya-which the Abhinavabhärati presents as an appendix, as a supplement to the sāmānyābhinaya -is the multicoloured and, so to speak, pictorial acting by which the world is theatrically depicted'. 
Although these acting methods are supposed to contain all four registers of acting, the sāmānyābhinaya undergoes a further subdivision into psychophysical (sāttvika), corporal (śärîra), and verbal (vācika), according to the predominant component in it. Among the three, the śärírasāmānyābhinaya is particularly relevant to the discussion of the difference between dance and theatre, since it displays a succession of phases in which the bodily movement becomes gradually entangled with the spoken word, each to different degrees. Its six phases are given in the following order: vākyäbhinaya ('verbal acting'), sūcā ('indicative acting'), àंkura ('sprout acting'), śākhā ('twig-limb acting'), nātyāyita ('simili-drama' or 'pseudo-drama') ${ }^{52}$, and nivrttyankura ('sprout at the end of the acting'). ${ }^{53}$ These various phases create, in the words of BansatBoudon (1992: 151), a true 'protocol of acting.' Two of them, the śa khā and the ankura, are listed in Nś 8.14 along with dance as components of the àngikäbhinaya, and therefore seem to represent different ways of using the body during the enactment, with different semiotic and expressive values. ${ }^{54}$ From this perspective, the special way in which dance contributes to the bodily enactment without being assimilated to it will be the central topic of discussion in the textual passage on the difference between dance and theatre, as translated and investigated in this book.

More than constituting an infallible means for reproducing external reality as faithful as possible, or providing an automatic mechanism for the actor to enact any kind of written text, this sophisticated acting protocol aims at unfolding all the implicit suggestions and shades of meaning latent in the dramatic text. With regard to its application to the play's text, the skill of a proficient

52 I follow Bansat-Boudon 1995:152 in this translation, based on the use of the denominative suffix -āy $a$ and middle endings, which adds the following meanings to the root based on which it is formed: 'to be like', 'act/behave like', 'play the part of'.

The vākyābhinaya is when the bodily acting is simultaneous with the recitation of the text; the sūca is a silent phase in which gestures alone convey the interior reflection of a character, followed by its enunciation through words; the arkura is the silent gestural phase that follows the verbal enunciation and reveals its latent meanings. The śa $k h \bar{a}$ is the coordinate movement of the head and face, legs and thighs, and hands and feet, on the verge of dance. The nattyāyita is of two types: the first is the acting of a play within the play, which corresponds roughly to the later garbhänka; the second is the enactment of a song inserted in the play, the dhruva . Lastly, the nivrttyankura is the display of the feelings of one character affected by the discourse of another. My understanding and rendering of the different phases of the śärīrasāmānyābhinaya closely follows Bansat-Boudon 1989-199o, 1992: $341-387$ and 1995. The latter contains a translation of Abhinavagupta's commentary with very telling examples of each phase taken from extant plays.

54 For a discussion of the semiotic and expressive value of dance within theatre, see $\S 3.4$ below. 
actor lay in his capacity to use all the means of enactment conjointly, with a view to realizing its emotional potential. The Abhinavabhäratī provides many an example of how the acting was to be carried out in extant plays, which includes different ways of enacting the same textual portion, ${ }^{55}$ as well as creative expansions of the transmitted versions of well-known plays. ${ }^{56}$ There was, as the examples suggest, a certain freedom on the part of the actor, which was disciplined by his mastery over the acting techniques on the one hand, and by his personal reflection and understanding of the import of the play on the other. Abhinavagupta, while reflecting on how an actor should apply the code of hand gestures to a certain scene, points out that a preliminary consideration of the meaning of the text (arthayukti) was required on his part. Actors should ponder which sense would be more logically and efficaciously enacted, be it the primary (mukhya), metaphorical (gauna), metonymical (läkșaṇika), or suggested (vyangya) one. ${ }^{57}$ In exceptional cases, one actor could choose to render several layers of meaning simultaneously, using different means of enactment at the same time. A very telling example is given in the Dhvanya alokalocana, in which a stanza of the Ratnāvali containing a double entendre in the form of a simile (upamāśleșa) is said to require that both levels of the simile be enacted, the primary meaning word by word, and the secondary meaning through looks and facial expressions. ${ }^{58}$

55 In the chapter on hastäbhinaya (ABh ad Nś ch. 9), some such examples are found, as for instance the option to enact an inaugural stanza either with a hand gesture for every word, or by rendering only the first element in a list or the main action. The example given is the nāndī of the Abhijñānaśákuntala ( $y \bar{a}$ sraștuh srșțir a adyā ...), in which the eight visible forms of Siva are described. A superior actor, says Abhinavagupta, should enact only the first two of the eight visible forms of Siva, i.e. water and fire, while an inferior one would represent many of the words because of his faltering nature. See ABh ad Nś 9.173, vol. 2, p. 67: atraika eva jalahutāśanābhinaya uttamena prayojyah. adhamena tv anekaś ca calasvabhāvatvāt.

$5^{6}$ For an example of a lāsyānga added in the second act of Śrī Harṣa’s Ratnāvalī, unnoticed in previous studies and alluded to in the discussion of the nature of dance, see Translation, n. 187. Many other instances of such insertions are reported in Bansat-Boudon 1992.

57 Cf. ABh ad Nś 9.164, vol. 2, p. 64: arthasyayuktir upapattiḥ mukhyagaunaläkșaṇikaryañgyādibhedena.

$5^{8}$ This is Ratnāvali 2.4 , where King Udayana is describing a vine in the palace garden which, he says, looks like a rival woman in love, namely Ratnāvalī, who has just arrived at the palace and is about to arouse the jealousy of the queen (for a translation, cf. Ingalls et al. 1990: 278). In explaining how this stanza should be represented on stage, Abhinavagupta says: abhinayo 'py atra prākaranike pratipadam. aprākaraṇike tu vākyārthā-

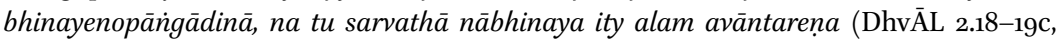
pp. 226-227): '[One may] also [note that] the acting out of the primarily intended meaning, [namely that pertaining to the vine,] should be at every word, while the acting out 
The image of the actor as a perfumer demands that he combine the basic ingredients in different doses and that, if the occasion requires it, he even choose to omit some of them. The moments of emotional intensity, in which the rasa is supposed to arise in the hearts of the spectators, appear to require a sort of suspension of the scenic action, in which gestures and speech become as if rarefied. In these crucial moments, the dramatic dialogues give way to the lyrical verses, by which the characters more poignantly express their states of mind. This kind of performance is considered to be of a superior type, especially when the character is caught in the act of experiencing his inner feelings. When no visible action takes place and everything occurs in an intimate sphere, suspended, so to say, within the texture of the dramatic text, the outer gestures become still; the dialogue, taking place inwardly, is then rendered through the subtle expression of sattva, and its text can be even taken up by a song. ${ }^{59}$

Even from such a limited number of stray examples, it should be clear that acting was not a matter of the mechanical application of a fixed code of gestures and conventional behaviours to the contents of a literary text and its vocal rendering. Rather, each course of action had to be carefully evaluated and constructed on stage by paying the utmost attention to the presence (or absence) of an emotionally demanding situation, around which different strategies-including the addition of scenic protocols, songs, and interludeswere developed. If Bharata had attempted to build a vocabulary for representing the world in theatre, Abhinavagupta is concerned with the creation of a proper scenic syntax, capable of conveying the full spectrum of the emotional sphere to the spectators. Apart from his glimpses into current scenic practices, suggesting a certain degree of autonomy on the part of the actor or theatre director with respect to the author's dramatic text, ${ }^{60}$ Abhinavagupta also stresses on several occasions that the śástra does not offer a complete catalogue of usages, but rather a vademecum for the artist. ${ }^{61}$ After this brief overview of act-

of the secondary meaning [which pertains to the woman] would be only of the general meaning of the stanza and should be effected by upāngas (facial gestures). On the other hand, it would be wrong to give no gesture at all [to the secondary meaning]. But enough on this incidental matter' (translation Ingalls et al. 1990: 279).

59 ABh ad Nś 9.173, vol. 2, p. 68: jyeșthe 'bhinaye pratyakșavartamānātmajñasthavișaye hastavyāpāro 'lpah. 'hiaa samassasa' ityādau. On the possible use of the example in Prakrit as occurring in concomitance with a lāsyānga involving a song in the Abhijñānaśākuntala, see Bansat-Boudon 1992: 332-337, and for a new hypothesis about its literary context, see Translation, n. 187.

6o A further evidence is the existence in manuscripts of 'inflated' or 'scenic' versions of some acts from famous plays, on which see Introduction, n. 24 .

61 On the scope of the śästra, see $\S 2.5$. 
ing as a bridge between the play and its stage performance, it is now time to turn to the mechanisms of dramatic communication vis-à-vis linguistic communication, as examined by Abhinavagupta and as discussed in other intellectual domains.

\subsection{Communication without Words}

Since their first textual codifications, the performing arts of India have been marked by a constant emphasis on the role played by emotions in these disciplines. In the case of a dramatic production, the rasa is said to pervade the whole process, from the composition of the dramatic text by the poet, its staging by actors, and, finally, its aesthetic apprehension by the spectators. ${ }^{62}$ Indeed, the very name ranga ('stage', but also 'auditorium') is said to derive from the Sanskrit root rañj, 'to colour', whereby theatre is the place where the mind becomes emotionally tinted. ${ }^{63}$ Despite the pervasiveness that had been assigned to emotions already in Bharata's treatise, precisely determining the nature and locus of rasa became an especially compelling question for literary critics. The dramatic changes that rasa underwent, as it was appropriated by Alaṃkāraśāstra, posed many a challenge to the adjacent field of Nāttyaśāstra, which prompted dramatic theorists to formulate more and more sophisticated analyses in order to re-appropriate rasa as a central concept in dramatic theory. As has been argued by Pollock, a turning point in aesthetic theory is represented by Bhațta Nāyaka, to whom we owe a decisive shift in focus from a formal to a reception analysis of rasa.${ }^{64}$ Following Bhațta Nāyaka in this and many other respects, Abhinavagupta conceptualizes rasa as an experience located in the spectator and, only by affinity, in the poet. ${ }^{65}$

62 The tree metaphor is famously used in Nātyaśästra 6.38: yathā büjād bhaved vṛsșo vṛkșāt pușpam phalam yathā| tathā mūlam rasāh sarve tebhyo bhāvā vyavasthitāh || 'Just as the tree comes from the seed, and from the tree the flower and the fruit, so the rasas are the root, and all the other emotional states are established from those.' According to Abhinavagupta, this indicates that the whole is pervaded by rasa: the root is the rasa belonging to the poet that, like a seed, develops into the poetic text, which is similar to a tree. With regard to the latter, the activities of the actor, consisting in the enactments (abhinaya), are like flowers, and the tasting of the rasa by the spectators is the fruit (cf. ABh ad Nś 6.38, vol. 1, p. 288).

63 Cf. ABh ad Nś 1.127, vol. 1, p. 46: rajyate 'neneti rañgo nātyam; ABh ad Nś 9.40, vol. 2, p. 34: rajyaty asmin hrdayam iti rañgah.

64 See Pollock 2010 and 2016: 144-148.

65 The poet is likened to a spectator who, Abhinava says - echoing his predecessor Ānandavardhana-looks at the world as if at a spectacle: kavir hi sāmājikatulya eva. tata evoktam ‘ṣrngārī cet kaviḥ' ityādy ānandavardhanācāryeṇa (ABh ad Nś 6.38, vol. 1, p. 288). 'The poet 
The whole problem of aesthetic communication coalesces around the passage of rasa from the poet to the spectator, while actors are explicitly excluded from it. The process of rasa communication is in fact described as a transferring or a pouring of rasa from heart to heart-the rasa is in fact first and foremost conceptualized as a liquid - in which the actor becomes a mere vessel for savouring the poem's taste: filled with its liquor, he is however untouched by it. ${ }^{66}$ We have seen in the previous section that the actor avails himself of a whole range of means of communication, especially designed to convey the complete emotional sphere as effectively as possible. However, what does it mean to represent an emotion dramatically if the actor is not intimately touched by it? ${ }^{67}$ Is his action limited to the imitation of the external signs of an emotion? And what does it mean to communicate an emotional meaning dramatically, by way of abhinaya? In what follows, I will take a closer look at the role of abhinaya as a function in the theatrical communication of rasa and its factors.

Although the four abhinayas are central to the effective communication of emotions in theatre, the aesthetic factors - the determinants, consequents,

is similar to a spectator. In this vein, Ānandavardhana said that "if the poet is full of love, etc."' The verse quoted is in the Vrtti ad DhvĀ 3.42, p. 498: śrngārī cet kavị kārye jātam rasamayam jagat | sa eva vītarāgaś cen nïrasam sarvam eva tat || 'If the poet is full of love, a world made of rasa will arise in his poem; if he himself is dispassionate, then everything will be devoid of rasa.' The idea that the poet looks at the world as a spectator is linked to the experience of Vālmīki, considered by tradition as the first poet (ādikavi). Witnessing a curlew's grief over the loss of his mate, slain by a hunter, Vālmīki transformed his own grief (śoka) into verse (śloka), and thus composed the Rāmāyaṇa (cf. DhĀ 1.5 and Vrtti thereon, translated in Ingalls et al. 1990: 113-114).

$66 \quad \mathrm{ABh}$ ad Nś 6.32-33, vol. 1, p. 285: ata eva ca națe na rasah. [...] națe tarhi kim. āsvādanopāyaḥ. ata eva ca pātram ity ucyate. na hi pātre madyāsvādaḥ. api tu tadupāyakaḥ. tena pramukhapātre [corr. Viśvesvara, cf. Pollock 2016: 391, n. 200, 'mātre $\mathrm{E}_{1}$ ] națopayoga ity alam. 'And so the rasa is not in the actor. [...] - What then is there in the actor?-He is the means of savouring. That is why he is called a vessel ( $p \bar{a}$ tra). For there is no savouring of the wine by the vessel, but yet it is instrumental to it. Therefore, actors are used as the main vessel [for the savouring of rasa].' The common argument used to exclude actors from the tasting of rasa is that if they were to taste the rasa, they would be unable to follow the rhythm, or would be caught, for instance, in the reality of the experiences represented, such as death. See DhĀL 2.4, p. 183: anukartari ca tadbhāve layādyananusaranam syāt; and ABh ad Nś 6.11, vol. 1, p. 258: națasya hi rasabhāvayoge maraṇādau tattvāveśo layādibhañgaś ca syāt.

67 Although the actor does not experience the rasa while he acts, he should not be thought of as an inert technician, as is suggested by the very existence of a psychophysical acting (sättvikäbhinaya), involving the use of the body-mind complex. For an in-depth study on the emotional and aesthetic experience of the actor in historical perspective, see Cuneo \& Ganser (forthcoming). 
and accompanying emotions - might well just be part of the literary description, and as such able to be conveyed by the mere power of words, as in the case of poetry meant to be heard and not enacted. From the time of Ānandavardhana, and with the incorporation of the rasa principle into Alaṃkāraśāstra, literary critics began to analyse poetry by paying particular attention to spotting the determinants and other factors leading to rasa in particular instances of poetic stanzas. The question of how poetic language could be expressive of rasa was first dealt with by Indian theoreticians within the boundaries of verbal language and linguistic analysis.

As Ānandhavardhana theorized in the Dhvanyāloka, poetic language possesses a special power, called vyañjana ('suggestion', 'manifestation'), capable of manifesting the unexpressed or implied meaning of poetry, characterized as dhvani (lit. 'sound', 'resonance'). He typically considered rasa or emotional content a type of dhvani - the highest in poetry - to be conveyed through this special mode of verbal signification. In Ānandavardhana's view, in fact, it is impossible to express the rasas by their names, in a purely denotative way (i.e. by abhidhā or vācakatva, in linguistic terminology), or through secondary or figurative expression (i.e. by gunavrtti or lakșanāa). Poets had to resort to a third linguistic function, the so-called 'suggestion' (vyañjanā), by which a rasa came to be manifested in the mind of the sensitive reader through the linguistic expression of the various aesthetic factors conveying it. As a corollary to this theory, it followed that rasa was to be conceived in poetry as a textual meaning or a linguistic entity, albeit one that could be expressed only indirectly by language. 68

Ānandavardhana essentially relied on dramatic speculation to extend rasa to poetry, conforming in particular to Bharata's famous dictum in the rasasūtra and the role of the aesthetic factors. He discussed poetic examples alongside dramatic ones, without ever transgressing the boundaries of linguistic analysis. Drawing on an earlier distinction in Alaṃkāraśāstra, he recognized a difference between poetry to be enacted (abhineyārtha-kārya) and poetry not to be enacted (anabhineyārtha-kārya). ${ }^{69}$ However, he never dealt with the consequences of such a difference in the medium of communication, as he failed to explore the potential of non-verbal communication alongside the dramatic text for the manifestation of rasa in theatre. This is all the more surprising given his familiarity with Bharata's text, and the latter's emphasis on the role of abhi-

68 On the controversy over the existence of dhvani, and the necessity to postulate a third power of language, see Ingalls et al. 199o; McCrea 2008; and Pollock 2012b, 2016.

69 See above, n. 35, for the definition of theatre as abhineyārtha in Bhāmaha. 
naya in conveying the various aesthetic factors leading to the arousal of rasa. ${ }^{70}$ Moreover, while claiming the independence of suggestion from the process of denotation, Ânandavardhana argued for its existence even outside the realm of poetic language:

The power of denotation (abhidhāna), in fact, is different from the power of suggestion (avagamana), because one sees that the sounds of a song or the like, although they do not have a denotative content (avācaka), can suggest objects such as those defined as rasa and so on, and because such non-verbal behaviours ( aśabda) as gestures (ceștā) are known to manifest particular meanings. Thus, a good poet has shown that a particular gesture can be the cause of manifestation of a meaning, as in the verse 'With her face bowed in shyness, etc..

Translation based on INGALLS et al. 1990: $555^{71}$

One may interpret the verse quoted here as an example of a gesture, i.e. bowing the head down, suggestive of an emotion in the character, i.e. shyness. However, Ānandavardhana quotes the full verse in an earlier passage of the Vrtti, which reveals a slightly more complex picture. The verse reads:

Her face was bowed in shyness

in the presence of our elders

and she forced back the grief

that gave motion to her breast.

But did not the mere corner of her eye,

lovelier than a startled deer's,

somehow, as it dropped a tear,

tell me not to go?

Translation INGALLS et al. 1990: $395^{72}$

70 See, for instance, the verses defining the various emotional states (bhāva), the determinants (vibhāva) and the consequents (anubhāva), all containing abhinaya as a principal component, in Nś $7.1-5$.

71 Vrtti ad DhvĀ 3.33, pp. 417-418: na hi yaivābhidhānaśaktih saivāvagamanaśaktih. avācakasyāpi gītaśabdāde rasādilakșaṇārthāvagamadarśanāt. aśabdasyāpi ceștāder arthaviśeșaprakāśanaprasiddheh. tathā hi 'vrīdāyogān natavadanayā' ityādiśloke ceștāviśeșah sukavinārthaprakāśanahetuh pradarśita eva.

72 Vrtti ad DhvĀ 3.4, pp. 305-307: vrị̄̂ayogān natavadanayā sannidhāne gurūṇām, baddhotkampạ̣ kucakalaśayor manyum antar nigrhhya | tișthety uktạ̣ kim iva na tayā yat samutsrijya bāṣpam, mayy āsaktaś cakitaharin̄ihārinetratribhägah || The verse is also found in the Süktimuktāvalī, as reported by Ingalls et al. 199o: 395, n. 1. 
In this stanza, the particular sidelong glance of the woman suggests, in a manner similar to that of verbal language, that the lover not leave. Somewhat surprisingly, in the Vrtti ad DhvĀ 3.4, where the verse is quoted in full, Ānandavardhana attributes the suggestive power of the stanza as a whole not to a gesture, but to the word tribhāga ('corner') in the compound 'netratribhāga' ('eye-corner') (ibid.). According to Abhinavagupta, the verse suggests love in separation - a rasa - which the reader understands from the presence of the word 'corner' (of the eye), together with the associations it evokes in the speaker, which acts as a stimulating determinant (uddīpana-[vibhāva]) triggering the context in which the emotion of the narrating voice arises. ${ }^{73}$

Although Ânandavardhana never explicitly attributes the capacity to suggest rasa to gestures, it is tempting to draw from his example an implicit distinction between the suggestiveness of gestures in human communication and the suggestiveness of gestures as embedded in poetic description. In the first instance, gestures can manifest specific meanings (artha) in the context of interlocution — just as language - while in the second, their suggestive power is assigned to words that are directed to the reader and - at least according to Abhinavagupta - are ultimately expressive of rasa. One may venture to argue that Ânandavardhana is aware of the potential of gestures to suggest emotions both in human and in poetic communication, and that he must have been aware of their centrality to dramatic communication or abhinaya in theatre; however, his aim in the Dhvanyāloka is restricted to explaining suggestion as a literary phenomenon and dhvani as a characteristic peculiar to the poetic text. $^{74}$

Poetic examples in which gestures play a prominent role in betraying and revealing human emotions abound in Ānandavardhana's illustrations of poems and dramatic stanzas containing rasa. This choice, one might argue, might be a consequence of the paradigmatic status that Bharata's rasasūtra assumed for literary critics. In the Nātyaśāstra, in fact, the illustration of the various aes-

73 See the translation of the Locana in Ingalls et al. 1990: 396 . The post-Bharata tradition commonly distinguishes two types of determinants: the foundational determinants ( $\bar{a} l a-$ mbanavibhāva), which are the support of the emotion, i.e. the characters, and the stimulating determinants (uddipanavibhāva), which consist in the contextual factors that facilitate the appearance of an emotion in the character. See, e.g., Ingalls et al. 1990: 16 and Pollock 2016: 7 .

74 As a matter of fact, Ānandavardhana recognizes suggestion in music and gestures, just as in ordinary language. As McCrea (2008: 186) puts it, 'While admitting that suggestiveness is a property of all human language, Ānandavardhana contends that in poetry this function of language takes on a special and unique importance which distinguishes it from the suggestive aspect of non-poetic language. Dhvani is not coterminous with suggestiveness'. 
thetic factors for each rasa and bhāva is laid down mainly in terms of gestures and visible actions, as befits theatrical communication. It is therefore quite understandable that, if rasa were to be found in literature as expressed by way of those same vibhāvas, anubhāvas, and vyabhicäribhāvas, examples containing a verbal description of the visible signs of an emotion, especially bodily gestures, would have been found to be particularly fitting for the sake of illustration. What may look somewhat paradoxical is that even while dealing with dramatic examples in particular, Ānandavardhana never takes into account how body language or other non-verbal behaviours-such as dance and musicmight have been used to communicate additional meaning in theatre, besides what was already expressed in the words of the playwright.

Some scholars have attempted to explain Ānandavardhana's way of analysing poetic and dramatic examples alike as a reflection, in the theory, of the collapse of the distinction between drama and poetry in practice, a position that was ultimately found to be untenable. ${ }^{75}$ Even a cursory look at the Sanskrit plays of the classical period reveals that we can find many examples of the full array of aesthetic factors as embedded in literary descriptions, without necessarily having to rely on enactment. One might easily be led to wonder if, in the light of the dhvani theory, which was a theory conceived within the boundaries of verbal language, enactment would contribute anything at all to the expression of rasa, even in theatre. Moreover, it is legitimate to ask the question of whether the poetic stanzas in dramas, which are privileged examples in Ānandavardhana's literary analysis, were originally conceived for enactment through gestures and facial expression in the same way as dramatic dialogues. ${ }^{76} \mathrm{~A}$ famous instance is the description of the

75 The hypothesis was advanced by Gerow and criticized by McCrea, cf. § 1.4, n. 116. Similarly, it has been commonly assumed that at some point around the end of the first millennium, Sanskrit drama stopped being performed, but continued to be composed throughout the second millennium as an exclusively literary form. For a criticism of this position, see Leclère 2010: 27, n. 5 .

$7^{6}$ As is well known, Sanskrit drama is a literary genre combining prose (gadya) and verse ( padya). In contemporary Kutiyattam, these textual portions are enacted differently: dramatic dialogues are usually rendered just through simple gestures, while poetic stanzas can be the object of long elaborations, and they are often the place for inserting side episodes or for giving full space to the play of emotions. The question of how poetic stanzas were rendered on stage must of course have been given different answers at different historical times and in different traditions of the performance of Sanskrit theatre. I have not been able to find any discussion on this topic in the theoretical texts, except for stray examples in Abhinavagupta's commentary and a distinction between prose (gadya) and verse (padya) in the corporal acting registers called vākyābhinaya and sūcā, on which see Bansat-Boudon 1992: 346-347. 
frightened deer chased by Dusyanta in the hunting scene at the opening of the Abhijñannaśākuntala. Here the deer, though not physically present on stage, is vividly described through the eyes of Dusyanta as displaying all the signs of fear:

Repeatedly darts a glance at the pursuing chariot, gracefully twisting his neck, with his haunches drawn acutely forward into his forebody out of fear of the arrow strike, scattering the path with grass half-chewed, dropping from his mouth gaping with exhaustion.

Look! With his lofty leaps he moves more through the sky and hardly touches the ground.

Abhijñānaśākuntala 1.2, Translation VASUdEVA 2006: 58

This literary passage displays all the elements that build up an emotion and lead to an aesthetic response, according to the well-known rasasütra: the element determining fear in the deer (vibhāva) is King Dusyanta himself, while the consequents of the fear (anubhāva) are the physical signs described in the stanza as being displayed by the deer, such as the turning of the neck, the open mouth dropping half-chewed grass, the contraction of the body, and the unsteady movements. The transitory states (vyabhicāribhāva) accompanying the main mood are impetus and exhaustion, evident from the deer's pace. All these elements converge in the stable state (sthāyibhāva) of fear (bhaya), and result in the rasa bhayannaka, the fearsome. Such analyses in terms of aesthetic factors are typical of the later commentators on drama. ${ }^{77}$ If rasa be part of poetry — and for Abhinavagupta, rasa will become definitional of all poetry-it has to be communicated in a way that conforms to the rasasūtra, i.e. through

77 This is how a commentator such as Rāghavabhațța ( $15^{\text {th c.) }}$ explains this verse, which coincides with similar analyses in dramatic treatises, where this verse is cited as an illustration of bhayannaka rasa. To the best of my knowledge, Abhinavagupta is the first to comment on this verse as an example of the fearsome rasa, although he does not comment on it in terms of the aesthetic factors, but focuses on the epistemology of rasa in terms of the spectator's cognition through the text and its performance. See the beginning of the siddhänta in ABh ad rasasūtra, quoted and discussed in Gnoli 1968; Cuneo 2008-2009; Pollock 2010, 2016; and David 2016. 
the display of the proper configuration of aesthetic elements rather than by mentioning the rasas directly by name. Ânandavardhana expresses this as follows:

The third variety [of suggested meaning], concerning the rasas and the like, becomes manifest when it is implied by the capacity of the expressed meaning (vācyasāmārthya), but it cannot directly be the object of the function of words. That is why it is different from the directly expressed meaning $(v \bar{a} c y a)$. To clarify: [a rasa] could be directly expressed either by making it known by its proper term, or by means of the communication of the aesthetic factors (vibhāvādi). In the first case, one would end up with the unwanted consequence that the rasas and so on would not be apprehended lest the proper terms [designating them] were made known. The [rasas], moreover, are not always made known by their proper terms. And even when that is the case, they are apprehended only by means of the communication of specific determinants etc. The proper terms [for the rasas etc.] would only confirm the apprehension, not constitute it. That is why we do not see the [rasas etc.] apprehended in other contexts. In a poem that merely contains isolated words such as 'love' and the like, without communicating the aesthetic factors, there is little apprehension that it contains rasa. And because of this positive and negative concomitance - that we apprehend the rasas even without their proper denotation, just through the specific determinants [consequents and transitory states], and that by their mere denotation we do not [necessarily] have [such] apprehension - the rasas can only be implied by the capacity of the denoted meaning and they cannot be denoted. Hence the third variety [of suggested meaning] is established as different from direct expression. ${ }^{78}$

${ }_{78} \quad V r t t i$ ad DhvĀ 1.4, pp. 78-84: tritīyas tu rasādilakṣaṇah prabhedo vācyasāmarthyākșiptah prakāśate, na tu sākșāc chabdavyāpāravișaya iti vācyād bhinna eva. tathā hi vācyatvam tasya svaśabdaniveditatvena vā syāt, vibhāvādipratipādanamukhena vā. pürvasmin pakṣe svaśabdaniveditatvābhāve rasādīnām apratītiprasañgah. na ca sarvatra teșām ș svśabdaniveditatvam. yatrāpy asti tat, tatrāpi viśiștavibhāvādipratipādanamukhenaivaișām pratītih. svaśabdena sā kevalam anūdyate, na tu tatkrtā vișayāntare tathā tasyā adarśanāt. na hi kevalaśrñgārādiśabdamātrabhāji vibhāvādipratipādanarahite kārye manāg api rasavattvapratītir asti. yataś ca svābhidhānam antareṇa kevalebhyo 'pi vibhāvādibhyo viśiștebhyo rasādīnām pratītih, kevalāc ca svābhidhānād apratītị, tasmād anvayavyatirekābhyām abhidheyasāmarthyākșiptatvam eva rasādīnām. na tv abhidheyatvam kathaṃcit, iti trtīyo 'pi prabhedo vācyād bhinna eveti sthitam. Translated also in Ingalls et al. 1990: 105106 and Pollock 2016: 90. 
Around the time of Ānandavardhana, Śrī Śankuka arrived at similar conclusions about the incommunicability of rasa through denotation, though starting from different premises. According to Śankkuka — as quoted by Abhinavagupta in the Abhinavabhäratī - the vibhāvas, anubhāvas, and vyabhicāribhāvas work as inferential signs (linga) in the cognition of a stable state (sthāyibhāva). This emotion is inferred as being in the actor, in the form of an imitation of the emotion belonging to the character, for instance Rāma. A rasa is nothing but this inferred emotion which, due to its being an imitation, is designated by a different name. ${ }^{79}$ While the other aesthetic factors can be known either through the poetic text or through their skilful display by an actor, the stable states cannot be simply denoted by their proper terms, but have to be communicated through dramatic enactment:

The determinants (vibhāva) can be realized on the strength of the poetic text; the consequents (anubhāva) by the training [of the actor] (śikșa); the transitory states (vyabhicārin) by force of presenting one's own factitious consequents. But the stable [state] (sthāyin) cannot be realized even on the strength of the poetic text. For words such as 'desire', 'grief', and so on, just make desire etc. into verbal referents through denotation, but do not communicate them in the form of vocal enactment. Since vocal [enactment] (vācika) is not simply the voice $(v \bar{a} k)$, but what is accomplished through the [voice], just as the bodily enactment (ängika) [is not just the body, but what is accomplished] through the limbs (anga). ${ }^{80}$

79 ABh ad rasasūtra, vol. 1, p. 266: tasmād dhetubhir vibhāvākhyaị kāryaiś cānubhāvātmabhị̣ sahacārirūpaiś ca vyabhicāribhih prayatnārjitatayā kṛtrimair api tathānabhimanyamānair anukartrsthatvena lingabalatah pratīyamānah sthāȳ bhāvo mukhyarāmādigatasthāyyanukaraṇarūpaḥ. anukaraṇarūpatvād eva nāmāntareṇa vyapadișto rasaḥ. 'The rasa is the stable state (sthāyi bhāva), in the form of an imitation (anukarana) of the stable [state] belonging to the character, such as Rāma. And it is simply because it is an imitation that it has been designated by a different name. It is apprehended as present in the actor by force of those inferential signs (linga): the causes, called determinants (vibhāva), the effects, i.e. the consequents (anubhāva), and the concomitant factors, consisting of the transitory [states] (vyabhicäri[bhāva]), all of which are, even though factitious-insofar as they are produced by an effort [of the actor] —not realized to be so.' (Translation based on Cuneo 2008-20091: 270).

8o ABh ad rasasūtra, vol. 1, pp. 266-267: vibhāvā hi kāryabalānusandheyāh. anubhāvāh śikșātạ. vyabhicāriṇah krtrimanijānubhāvārjanabalāt. sthāyī tu kāryabalād api nānusandheyah. 'ratih śoka' ityādayo hi śabdā ratyādikam abhidheyīkurvanty abhidhānatvena. na tu vācikābhinayarūpatayā 'vagamayanti. na hi vāg eva vācikam. api tu tayā nirvṛttam. añgair ivāngikam. 
This theoretical explanation is followed by some examples in which the stable states are either merely denoted (abhidheya) or more effectively enacted (abhineya). The second case, which interests us here, is exemplified through a verse pronounced by King Udayana in the Ratnāvalī, when he looks at a portrait in which Sāgarikā has depicted him in her company:

The flood of spraying tear-drops

that fell from her as she sketched

seems like sweat breaking out on my body

from the touch of the palm of her hand.

Translation DONIGER 2006: $153^{81}$

Śrī Śankkuka explains it thus:

While it denotes ( $a b h i-d h \bar{a}-)$ its own meaning, this very sentence enacts

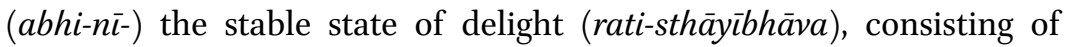
pleasure, pertaining to Udayana. But it does not state it [directly]. For dramatic enactment (abhinayana) is a power of communication (avagamanaśakti) different from verbal denotation (vācakatva). ${ }^{82}$

The example from the Ratnāvali is quite obviously presented as a case of vocal enactment ( vācikābhinaya), in which all the aesthetic factors are made known by means of the sentence ( $v \bar{a} k y a)$ alone, including perspiration, which is normally counted among those psychophysical reactions that can be rendered visually by a good actor, the sâttvikabhāvas. The underlying stable state is said to be enacted rather than being mentioned explicitly. If we connect Śankkuka's analysis of the mechanism of communication at play in this stanza with what was stated immediately before, it appears that abhinaya is a special power of communication, and that it works through inference. What is inferred is a state, which is imitated. It appears that the function assigned to abhinaya by Śankuka is similar to the one assigned to poetic suggestion by Ānandavardhana. ${ }^{83}$ Both

81 Ratnāvalī 2.12, bhāti patito likhantyāḥ tasyā bāṣpāmbuślkarakaṇaughaḥ| svedodgama iva karatalasamsparśād eșa me vapuși || Quoted in ABh ad rasasūtra, vol. 1, p. 267.

82 ABh ad rasasūtra, vol. 1, p. 267: ity anena tu vākyena svārtham abhidadhatā udayanagatặ sukhātmā ratịh sthāȳībhāvo 'bhinīyate na tūcyate. avagamanaśaktir hy abhinayanam vācakatvād anyā.

83 Cuneo $\left(2008-2009_{1}: 271\right.$, n. 150) first pointed out the similarity between the communicative power of representation postulated by Śankuka and Ānandavardhana's dhvani theory. Building on this insight, I try to show here the limits of Śankkuka's theory, and how in his example he fails, despite the very promising declaration of intent, to properly deal with the spectacular dimension of abhinaya. 
have a special status in aesthetic communication: they are effective in conveying emotions, and they are distinguished from direct denotation. Note also the similarity of their formulations:

- na hiyaivābhidhānaśaktiḥ saivāvagamanaśaktih (Vrtti ad DhvĀ 3.33, p. 417)

- avagamanaśaktir hyabhinayanaṃ vācakatvād anyā (ABh ad rasasūtra, vol. 1, p. 267)

Although Ānandavardhana aimed at extending suggestiveness to domains other than words, such as music and gestures, he does not take into consideration enactment as a separate medium for the dramatic suggestion of rasa. Analogously, Śankkuka identifies dramatic enactment (abhinaya) as the specific medium for conveying rasa in theatre, but he does so within the boundaries of vocal enactment as confined to the verbal text, without exploring - at least in the restricted number of fragments we possess - the suggestive potential of an actor's non-verbal communication. The fact that Śankuka mentions the case of bodily enactment, alongside the vocal, suggests that his theory was supposed to be valid for gestures as well. ${ }^{84}$

Although Śankuka's examples draw the distinction between verbal denotation and vocal enactment on purely textual grounds, the stage dimension of abhinaya is not altogether neglected. First of all, Sańkuka mentions the training of the actor and his capacity to communicate the transitory states by presenting his own factitious consequents, by which one has to understand the physical reactions affecting his voice and body. The various aesthetic factors, apprehended from the text and from the actor's enactment, operate jointly as inferential signs, by which the emotion - actually belonging to the character-is inferred as abiding in the actor. In the latter, however, it is only the imitation of an emotion acquired through conscious effort, not a genuine one, and takes the name of rasa. Secondly, since his work was a commentary on the Nātyaśāstra, Śankkuka's notion of abhinaya must necessarily have been quite ample, so as to include the whole spectrum of the means of enactment, among which bodily movement was a primary medium for conveying emotions. To Śańkuka goes the credit of formulating what can be regarded as the first theoretical attempt to combine verbal and non-verbal media for the effective communication of theatrical emotions. His choice of an example of abhinaya in which rasa is enhanced by gestures and psychophysical reactions - the falling drops, the

84 It is difficult to establish whether Ānandavardhana borrowed from Śrī Śaṅkuka or vice versa. For an argument in favour of Śankuka's predating Ānandavardhana on the basis of later evidence about their different patronage, see Pollock 2016: 77. According to Pollock (ibid.: 13), Śankuka was the first to formulate a distinction between referential and expressive language. 
action of painting, the appearance of perspiration, the touch of the handwhich are all just part of the literary description, might be regarded as stemming from a general hesitation to combine words and gestures more effectively in a comprehensive theory of aesthetic communication.

While in oral literature the function by which rasa is communicated is taken up by vyañjan $\bar{a}$ - the linguistic function newly theorized by Ānandavardhana-in visual literature the communication of rasa is assumed by abhinaya, already defined by Bharata as the very medium for conveying emotions in a theatrical context. ${ }^{85}$ Besides the technical but rather unspecific definition of abhinaya in the Nātyaśāstra, we find another, conventional meaning attached to this term in Indian philosophy, especially within discussions about knowledge acquisition and the validity of the means of knowledge, the socalled pramannas. The view that gestures and movements communicate meaning by inference is not an original position of Śankuka, but is rather the communis opinio in Indian sources. Gestures (including facial expressions) and movements, designated in these texts by the comprehensive term cesț $\bar{a}$, are recognized to have the power to make something known, and this something is sometimes identified with the inner states of the mind. Some philosophical schools therefore list gestures among the pramānas, typically as a special type of inference. The Praśastapādabhāssya, a Vaiśeșika text from the fifth or sixth century CE also known as Padārthadharmasamgraha, maintains that gestures produce a cognition for someone who knows abhinaya, that is, one who knows the invariable concomitance between specific bodily actions and meaning:

Since we see that a cognition comes about through bodily gestures (cesț $\bar{a})$, for the one who is acquainted with gesticulation (abhinaya), even the [cognition issuing thereof] has to be regarded as a case of inference. ${ }^{86}$

The available commentaries on this verse especially stress the fact that gesticulation should fall under the category of inference or, in some cases, even of verbal knowledge. ${ }^{87}$ However one considers them, gestures cannot be thought

85 See above, n. 38, on the definition of abhinaya in the Nātyaśāstra.

86 PDhS, p. 48 (anumānaprakaraṇam): prasiddhābhinayasya ceștayā pratipattidarśanāt tad apy anumānam eva.

87 This is the case of the Kiranāvalī, Udayana's commentary on the Padārthadharmasamgraha, where the most detailed commentary on this verse is found. Udayana analyses both positions: 1) gestures work as the signs of an inference; 2) gestures function like words. In the second case, gestures are compared to writing (lipivat), which works through 
of as independent means since, for them to produce knowledge, it is necessary to have a previous knowledge of the connection between, say, a certain way of moving the palms and the fingers of the hands, and a meaning, for instance calling or sending somebody away. ${ }^{88}$ The Vyomavatī, a commentary on the Padārthadharmasamgraha written by Vyomaśiva around $900 \mathrm{CE}$, uses the following example for a gesture producing knowledge by inference: I see a man raising his cupped hands to his mouth, and I infer that he is thirsty. The source for the knowledge of the invariable connection between the two is the direct observation of worldly behaviour. However, Vyomaśiva adds:

In this way, other kinds of gestures (ceștā), known from the science of theatre (nātyaśāstraprasiddha), should also be subsumed under inference. ${ }^{89}$

These examples suggest that, outside the specialized field of theatre, the word abhinaya was understood primarily as gesticulation, as a worldly way of communicating without words, and that this was mainly understood to work by inference, by means of a conventional relation between gestures and meanings. Paradigmatic of this kind of bodily behaviour are certainly the gestures of the hands, but examples with other kinds of expressive gestures are not lacking in philosophical sources. An oft-cited example is that of the winking of the eyes

the memory of the words with which the graphic signs are associated, and would in any case still fall under anumāna, since even verbal knowledge is subsumed under inference according to the Vaiśeșika thinkers. Cf. Kiraṇāvalī, pp. 213-214.

88 Interestingly, in a note on his translation of Śrīdhara's Nyāyakandalī, Ganganath Jha (1982: 466) says that those who take gestures as an independent means of knowledge are the Tāntrikas. Unfortunately, I have not been able to trace the source of this statement in the available literature.

89 Vyomavatī, p. 175: evam anyāpi ceștā nātyaśāstraprasiddhā anumāne 'ntarbhāvanìyeti. The opposition of 'world' and 'science of theatre' is not given explicitly by Vyomaśiva, but it is found in another source, Bhāsarvajña's Nyāyabhūṣana (9th c.) in the context of a similar discussion about the status of ceștā as pramāna, where it is recognized to be part of inference on the strength of similar arguments as those of the Vaiśeșikas. Again, the point of departure is that some people consider ceșța as an independent pramāna. Nyāyabhūṣana, p. 435: anye tu ceșțākhyam pramānam icchanti. kā punar iyam ceșteti? prayatnajanitā śarīratadavayavānām kriyā ceșțā. sā nātyaśāstraprasiddhasamayabalena lokakrtasamayabalena ca purușābhiprāyaviśeșam arthaviśeșam ca pratipādayantī pramāṇam isyate. 'Some, however, consider the one called ceșța a valid means of knowledge. What is then this ceștāe Ceștā is the activity of the body and its limbs, brought about through an effort. This is considered as a pramāna, since it conveys the particular intention of a man, or a particular meaning, on the force of the convention known from the science of theatre and on the force of the convention established in the world.' 
(akșinikoca), to which the Dhvanyālokalocana even assigns a method (mārga), similar to dancing and singing. ${ }^{90}$ Before that, grammarians typically took the winking of the eyes as an analogy for the functioning of what they considered as incorrect linguistic forms, such as Apabhramśa words. These-explains the philosopher of language Bhartrihari-do not convey their object directly, but indirectly, either by prompting recollection of the correct word through inference, or by conveying just a vague idea, by force of repetition, similar to the way madmen communicate by winking their eyes. ${ }^{91}$ Bhartṛhari's testimony is interesting, since it reflects a negative opinion about gesticulation intended as an indistinct form of language, conveying ideas in a confused way.

Within the theatrical sphere, Abhinavagupta analogously explains the profusion of gestures used to enact certain dramatic scenes as reflecting the mental condition of the character, which in its turn is based on worldly behaviour. In the world, in fact, the excessive use of gestures is attributed to a lack of mental clarity affecting bodily expression. Here one may be tempted to read an indirect allusion to the opposite appraisal of the mastery over one's own psychophysical sphere, typical of a certain courtly milieu ${ }^{92}$ The philosophical cliché that gesticulation reflects mental confusion is typically used by Abhinavagupta in other works to mock the opponent's way of arguing. One instance is the humorous description of a Buddhist's definition of the means of correct knowledge (pramāna) in the İ́svarapratyabhijñāvivrtivimarśinī: 'This [argument] amounts to nothing but a grimace, a shaking of the head, a snap of the fingers and the like' (Ratié 2013: 384, n. 29). ${ }^{93}$ In a verse by Manoratha, quoted by Abhinavagupta in his Locana, it is the lack of mindfulness on the part of the interlocutor that triggers a dialogue through gestures, clearly expressing scornful derision: 'If a fool asked him [to define dhvani], he could reply with such [silly gestures] as raising the eyebrows and rolling his eyes' (Ingalls et al. 1990: 6263). ${ }^{94}$ Such examples show that Abhinavagupta was aware of the common negative value assigned to gestures in other spheres, but he certainly did not put it on the same plane as the use of gestures proper to aesthetic communication in theatre, i.e. abhinaya.

$90 \quad$ See DhvāL 1.1, p. 22: mārgasyeti. nṛttagìtākșinikocanādiprāyasyety arthaḥ.

91 See Vrtti ad VP 1.147, p. 235: tatra tu sādhuryavahitā vā bhavaty arthapratipattir abhyāsād vā pramattānām akșinikocādivat saṃpratyayamātraṃ jāyate.

92 For a broader context of the court and its practices, see Ali 2006. With reference to psychophysical practices and following Michel Foucault, Ali speaks of 'technologies of the self' (Ali 1998) and of 'aristocratic body techniques' (Ali 2008). For a treatment of this issue from an actor's point of view, see Cuneo \& Ganser (forthcoming).

93 İPVV 2.3, vol. 1, p. 91: mukhabhañgamūrdhakampāngulimoțanādimātratattvam tat.

94 DhvĀL 1.1, p. 27: jadena prșțo bhrūbhangakațākṣādibhir evottaraṃ dadat. 
Vyomaśiva's evidence marks an important step towards the understanding of dramatic enactment as a sphere separate from worldly communication, as is mirrored in Śankuka's discussion of the function of abhinaya. But the credit for definitively separating the common sense of abhinaya in worldly communication from the abhinaya proper to aesthetic communication, including in its epistemological modalities, goes to Abhinavagupta. As will be shown in the next section, Abhinavagupta distinguished dramatic enactment both from the sphere of inference and from that of linguistic expression, giving abhinaya a totally new interpretation as a case of direct perception, though a very special one. The formulation of a comprehensive theory, capable of accommodating not only the coordinated actions of speech and gestures, together with costumes and psychophysical reactions, but also the non-representational elements, such as music and dance, was a task our commentator consciously assumed. In what follows, his main presuppositions and achievements will be outlined.

\subsubsection{Dramatic Mimesis vs Imitation}

In the previous sections, the close connection between dramatic enactment and emotions has been investigated both with regard to the actor's training, and as grounded in a literary text. It has been noticed how, around the ninth and tenth centuries, the abhinaya of theatre started to be recognized as a specific domain even outside specialistic literature on drama, and how, in the newly enlarged field of literary criticism, attempts were being made to link the question of abhinaya, as the specifics of theatre, to the new theories of suggestiveness in poetic analysis. In order to understand Abhinavagupta's redefinition of the status of abhinaya as dramatic mimesis (read 'the mimesis proper to drama'), it is now necessary to delve into its theoretical premises, which concern the phenomenological and epistemological status of dramatic fiction. Abhinavagupta takes his cues from the critique of imitation in theatre. It is well known that he rejected the view that theatre is an imitation (anukrti) anukāra/anukarana) both of the world more generally and of emotions in particular. As I will argue, however, it would be a mistake to draw the conclusion that literature and drama-just like painting and sculpture, according to a prejudice common in early twentieth-century perceptions of Indian art-knew no realism whatsoever and preferred to linger on inner and spiritual essences rather than representing external realities. ${ }^{95}$ At the same time, I would like to rehabilitate the concept of mimesis in Indian theatre as a possible equivalent

95 For a recent re-evaluation of imitation in Indian art, see Dave-Mukherji 2016. DaveMukherji equates anukarana with mimesis, which she understands as imitation or real- 
for abhinaya. Given the shifts in usage that the term mimesis has undergone in Western theories of representation over the long history of this concept, it would be restrictive to intend mimesis in the limited sense of imitation-quamimicry, ${ }^{96}$ which is how scholars commonly understand the term anukarana in art after its dismantling by Abhinavagupta.

Following his master Bhatța Tauta, Abhinavagupta rejects the logical possibility that representation in theatre could be conceived as imitation-quamimicry. This theoretical position, however, did not prevent further discussion on representation, on the status of fiction and on the status of reality in art. On the contrary, the rejection of imitation provides an occasion for Abhinavagupta to reflect on the particular status of representation in art and of dramatic representation in particular. If we regard 'mimesis as a concept (or rather a family of concepts) of representation', as Halliwell (2002: 16) proposed for the history of mimesis in the West, it becomes possible to view Śankuka's theory of anukarana and Bhatța Tauta/Abhinavagupta's rejection of it as part of a continuous discourse on mimesis-in the larger sense of representation-cumexpression - rather than in terms of a rupture with the idea of art as imitation tout court, as it has commonly been understood. As I will argue, the concept of abhinaya plays a crucial role in Abhinavagupta's framing of the concept of mimesis in Indian theatre, not only as an artistic medium with the meaning of dramatic acting, but as a mode of representation entailing a reflection on the audience's cognition of theatre and the ontological status of the world represented. The discourse on representation and abhinaya will be particularly relevant in the discussion of mimetic or narrative dance, where the possibility that dance, just like theatre, may function through abhinaya becomes a debated issue. The discussion will be framed by Abhinavagupta as a reflection on the specificity of dramatic mimesis and what should fall outside of its semantic field. Unlike for Aristotle, the discourse on mimesis in Abhinavagupta does not take the form of a discourse on the representational arts in general, but on the status of 'perfect' and 'imperfect' mimesis, whose paradigmatic form is Sanskrit drama.

ism, a position that is not shared by the present author. On the genesis of the prejudice about the lack of imitation-qua-realism in the Indian arts, as it emerged in the crosscultural exchange between India and Europe in the early twentieth century, see Ganser 2018.

96 A good point of departure for looking at the shifting concept of mimesis from antiquity onwards is Halliwell 2002. According to Halliwell, mimesis was intended in antiquity in the sense of representation-cum-expression, and it was not until the eighteenth century that its semantic sphere was narrowed down to signify imitation, with the negative connotation of the 'copy', 'replica' or even 'counterfeit' (ibid.: 13-14). 
To begin with, it would be useful to have a look at what was understood by the term anukarana in theatre, and what the theory of imitation-anukarana$v \bar{a} d a$ is a term used in the Abhinavabhāratī to refer to Śrī Śankuka's thesisimplied for its most fervent supporter. Although Śankuka's theory is essentially presented as an interpretation of rasa as an imitated emotion known via inference, its refutation is connected with a larger critique of theatre as imitation. Abhinavagupta imparts the first blows to this theory in the first chapter of the Abhinavabhäratī, taking Bharata's statement that theatre is an imitation of the seven continents (saptadvīpannukaraṇa, Nś 1.117) as his point of departure. The second and fatal blow arrives with the already mentioned refutation of Śankuka's thesis on rasa in the sixth chapter. As the number of intertextual references between these two chapters indicates, the two critiques should be read as closely interconnected. Since the relevant portions are available in a number of translations nowadays, ${ }^{97} \mathrm{I}$ will limit my account to presenting the arguments for establishing a special status for aesthetic communication that accounts for the full spectrum of representational media, in which dramatic mimesis is irrevocably divorced from imitation, and its epistemology from inference.

Let me start with the limited critique of rasa as the imitation of an emotion. In its basic form, according to Śrī Śankuka's anukaranavāda, a stable state (sthāyibhāva) is cognized as being in the actor-the anukartr-by force of the inferential signs (linga) consisting in the aesthetic factors (vibhāvādi), which correspond to the causes, effects, and accompanying elements that configure a certain emotion in real life. The stable state inferred from them is an imitation (anukarana) of the stable state belonging to the character-the anukārya - and takes the name of rasa. ${ }^{98}$ The main problem highlighted by Bhața Tauta/Abhinavagupta does not concern the cognition of emotions by means of some externally visible signs acting as inferential reasons (linga), ${ }^{99}$ but Śankuka's explanation of the object inferred in theatre as the imitation of an emotion and not simply as the emotion itself, just as in real life. The idea that rasa is an imitation of the emotion of a fictional character, in fact, is triggered

97 Most importantly in Gnoli 1968, Cuneo 2008-2009, and Pollock 2016.

98 The theory is summarized in the concise formula 'bhāvānukaraṇam rasāḥ' ( $\mathrm{ABh}$ ad rasasütra, vol. 1, p. 270). For details, see above, n. 79 .

99 As also stated at the beginning of the section on the essence of rasa, we recognize emotions in theatre because we have learned to infer other people's emotions from the display of the appropriate signs in real life. See ABh ad rasasūtra, vol. 1, p. 278: tatra lokavyavahāre kāryakāraṇasahacārātmakalingadarśane sthāyyātmaparacittavrttyanumānābhyāsapāta$v \bar{a} d[\ldots]$ 'In this regard, in ordinary life, one develops, through repeated practice, the ability to infer the stable states belonging to others, by seeing the inferential signs consisting of causes, effects, and concomitant elements.' 
by the fictional context of the theatrical performance or poem. This, according to Śankuka, accounts for the unreality of the events represented or depicted, including the emotions. At the same time, however, he seems to argue that the spectators do not recognize the aesthetic factors as factitious, otherwise the inferential process would be invalidated.

Now, Bhatta Tauta argued that for rasa to be an imitation, somebody has to apprehend it as an imitation and not as the real thing, which means that a distinction has to be made between the imitator, the imitated, and the term of the imitation. The example he gives is the imitation of somebody drinking alcohol in a particular way. For it to be grasped as an imitation, the imitator must be perceived drinking water, which would be the term of the imitation standing for the imitated thing. ${ }^{100}$ Analogously, to apprehend rasa in theatre as an imitation, a spectator would have to apprehend the actor as the imitator of the character's emotion by means of something analogous but not equal to that emotion. It would be difficult, however, to see how the perception of the external paraphernalia of an actor, or his actions and psychophysical reactions, would lead to the cognition of the imitation of an emotion, and how that imitated emotion could be attributed to a fictional character, like Rāma, that nobody has ever seen. ${ }^{101}$ Moreover, the only way to explain how the inferential

100 ABh ad rasasūtra, vol. 1, p. 268: kiṃcid dhi pramānenopalabdham tad anukaraṇam iti śakyam vaktum. yathā 'evam asau surām pibati' iti surāpānānukaraṇatvena paya hpānam pratyakșāvalokitam pratibhāti. 'Something can be called an imitation when it is grasped as such by a valid means of knowledge. For instance, the cognition "he drinks alcohol in this way" manifests itself as the imitation of the drinking of alcohol when the drinking of water is directly perceived' (Translation based on Pollock 2016: 183-184). The context for this particular case of imitation is not totally clear; possibly, it was intended as a case of mimicry aimed at caricaturing someone, not necessarily a case of fiction, and certainly not a trompe-l' œil. To convey the idea of drinking on stage, in fact, an actor would normally just reach up with his hands to his mouth, possibly displaying afterwards the effects of intoxication (mada being one of the 33 ryabhicāribhāvas) through the appropriate anubhāvas, thereby conveying the idea of an intoxicating drink.

101 ABh ad rasasütra, vol. 1, p. 268: iha ca națagatam kim tad upalabdham yad ratyanukarañatayā bhātīti cintyam. taccharīram tanniștham pratisisirșakādi romāñ̃akagadgadikādi bhujākșepavalanaprabhṛti bhrūkșepakațākșādikam ca na rateś cittavrttirūpatayānukāratvena kasyacit pratibhäti. jaḍatvena bhinnendriyagrāhyatvena bhinnādhikarañatvena ca tato 'tivailakșanyāt. mukhyāvalokane ca tadanukaranapratibhāsaḥ. na ca rāmagatām ratim upalabdhapūrvinạ kecit. etena rāmānukārī nața ity api nirastạ̣ pravādaḥ. 'In the case [of theatre], one has to reflect on what it is that one perceives in the actor, which looks like the imitation of desire. The body of the actor, the headdress and the other [elements of the costume] fixed on him, [the psychophysical reactions] such as horripilation, stammering and so on, the shaking and spinning of his arms, the frowns of the eyebrows, the side glances and so on; for nobody does this appear as an imitation of the mental state of desire, 
signs of an emotion, i.e. the determinants, the consequents, and the transitory states, could lead a spectator to apprehend the imitation of an emotion instead of the emotion itself would be to admit that they are indeed grasped as fictitious. And this leads to an impasse, since it invalidates the possibility of inferring either a real emotion or an imitated one: from a fake inferential sign recognized as such, it is neither possible to infer something real nor something imitated. In the famous example used in the Abhinavabhäratī, mist perceived as an imitation of smoke cannot lead one to infer a bouquet of red flowers as an imitation of fire.

The discussion then shifts from an epistemological to a phenomenological plane, where the acting process is examined for evidence for the claim that the actor is imitating the character's emotion. But this would be untenable since, even if imitation (anu-karana) be understood as 'making similar to' (sadrśa-karana), the actor, just like the audience, has never seen Rāma, let alone his emotion. The experience of the actor is described as follows by Bhața Tauta/Abhinavagupta:

Moreover, the actor simply gesticulates (ceștate), while displaying ( $p r a-$ darśayan) the consequents alone - thanks to his training, to the recollection of his own determinants, and to his empathy through the generalization of the emotion [in the text] —and while reciting (pațan) the poetic text with the help of the appropriate intonations etc. To this alone amounts his experience, but he does not have the experience that [what he is doing] is an imitation. For there can be no imitation of the gestures of Rāma (rāmaceștita-anukāra) in the same way that the attire of the beloved can be imitated (kāntaveșa-anukāra). Moreover, we have already explained this in the first chapter. ${ }^{102}$

since, given that they are insentient and therefore grasped by different sense organs, and that they have different substrata, [these external manifestations] are radically different from desire. And if one argues that the imitation of [desire] is manifested as observed in the character, our answer is that nobody has ever perceived the desire belonging to Rāma. Therefore, to say that the actor is imitating Rāma is just empty talk' (Translation based on Pollock 2016: 184).

102 ABh ad rasasūtra, vol. 1, pp. 269-270: kim ca națah śikșāvaśāt svavibhāvasmaraṇāc cittavrttisādhāran̄ibhāvena hrdayasaṃvādāt kevalam anubhāvān pradarśayan kāvyam ucitakākuprabhrtyupaskāreṇa pațhaṇs ceștata ity etāvan mātre 'sya pratīitir na tv anukāraṃ vedayate. *kāntaveșānukāravad dhi [conj. Gnoli, 'ānukāravrddhi $\mathrm{E}_{1}$ ] na rāmaceștitasyānukārah. etac ca prathamādhyāye 'pi darśitam asmābhih. In his translation, Gnoli refers to one of the graces of women known in the Nätyaśāstra as līlā, in which the woman dresses up and makes a mimicry of the lover's appearance and speech to amuse her companion friend (Gnoli 1968: 40). The reference to the practice of lïla and its resulting in somebody 
The reference to the Abhinavabhäratì's first chapter in this passage has the function of connecting the critique of rasa as the imitation of an emotion with the more general critique of theatre as an imitation-qua-mimicry. A similar phrasing and reference to the general rejection of imitation in theatre is found just a few lines below the above-quoted passage, while discussing the possibility that Bharata could ever have meant rasa as the imitation of a stable state:

As to the statement that '[theatre] is an imitation (anukarana) of the seven continents' ( $\mathrm{Ns} 1.117 \mathrm{~cd}$ ), it can be explained in a different way. Moreover, even if one admits that there is imitation of the [stable state], why is there not a different name [i.e. rasa] in the case of the imitation of the attire and the gait of the beloved (käntaveșagaty-anukarana)? ${ }^{103}$

As this passage hints, in the first chapter Abhinavagupta sets out to justify Bharata's use of the word anukarana. Many of the arguments used by Bhața Tauta to refute Śankuka's theory of rasa as imitation are reused in the first chapter to refute the general idea that theatre is an imitation. However, since the first chapter does not aim to counter Śankkuka's thesis, but to explain Bharata's - at first view-puzzling statement that 'theatre is an imitation (anukarana) of the seven continents' (Nś 1.117cd), it provides the occasion for presenting a general theory of what theatre is and does. Abhinavagupta takes his cue from Bharata's use of another term, i.e. anukirtana, in Nś $1.107 \mathrm{~cd}$, to which he assigns a meaning different from imitation, namely 'celebrative renarration' of the three worlds. The term anukarana would then be reinterpreted as similarly nuanced, thereby justifying Bharata's use of it. ${ }^{104}$ Bharata's statement that theatre is an imitation of the seven continents in Nś $1.117 \mathrm{~cd}$ is moreover acceptable, provided that the term nătya in it is understood as 'the activity

else's amusement is pertinent, since it is analogous to the case of parody or caricature (vikäraṇa), which is described in ABh ad Nś 1.107, vol. 1, p. 36 as one of the possible senses of anukarana.

103 ABh ad rasasūtra, vol. 1, p. 270: saptadvīpānukaraṇam ityāditvanyathāpi śakyagamanikam iti. tadanukāre 'pi ca kva nāmāntaram kāntaveșagatyanukaraṇādau. My translation, on the whole, follows Pollock 2016: 186. Cf. also Gnoli 1968: 41, and Cuneo 2008-20091: 278, who understand the passage slightly differently.

104 The relevant verses are Nś 1.107cd: trailokyasyāsya sarvasya nātyam bhāvānukīrtanam \| 'Theatre is the renarration of the states of these three entire worlds', and Nś 1.117cd: saptadvīpānukaranam nātyam etad bhavisyati || 'This theatre will be an imitation of the seven continents.' NŚ 1.112 also defines theatre as 'an imitation of the conduct of common people' (lokavrttānukarana). On the notions of anukīrtana and anukarana, see Bansat-Boudon 1992: 125-127. 
of actors, consisting of an imitation of the seven continents, that one sees on stage' (saptadvīpānukaranamayī hi națakriyā rañge drśyate, $\mathrm{ABh}$ ad locum, vol. 1, p. 42). At this juncture, there is an interesting overlap, never made explicit as such by Abhinavagupta, between the concept of anukarana and that of abhinaya. What could the activity of actors-conforming to the ways of the world and seen on stage - ever be, other than dramatic acting, i.e. abhinaya? Abhinaya is the activity of actors par excellence, and it is often qualified in terms of activity (kriyā) in the Abhinavabhäratī. ${ }^{105}$ As to the reference to Nś $1.117 \mathrm{~cd}$ in the quotation from the rasasütra discussed above, it must hint at this interpretation of anukarana as the activities of actors on stage, which correspond largely to worldly ones, according to the sense of anukarana as anusaritaya karana ('acting in conformity [with the world]' ABh ad Nś 1.107cd, vol. 1, p. 37). To say that their activities conform to the ways of the world is indeed utterly different from saying that the actors imitate the emotions while acting. Clearly, the discourse on anukarana in the first chapter is intended as a general discourse on representation in theatre, in which imitation is just one of the possible options for thinking about the connection between art and reality. And that is rejected as an impossibility under every point of view. 106

The challenge posed by Śrī Śankuka's anukaranavāda was to theoretically distinguish the aesthetic factors leading to the cognition of rasa in theatre from the corresponding inferential signs leading to the inference of emotions in real life, without letting the whole distinction between art and life collapse. Emotions or bhāvas are acknowledged almost unanimously by Indian literary critics to exist in the world and in theatre alike, and in both domains they are displayed through the same configuration of external signs. In art, however, emotions are conveyed conjointly by the literary text and by actors displaying the appropriate visible reactions on their body. According to Abhinavagupta, Śankkuka's

105 See, for instance, Abhinavagupta's insistence on the sāmānyābhinaya as having the character of an activity $(k r i y \bar{a})$, with some reservations about the āhäryābhinaya; cf. BansatBoudon 1992: 345 and 363, n. 358 .

106 The verses under discussion are part of Brahmā's discourse on the nature of theatre, pronounced to pacify the obstacles (Nś 1.106-119), who had mistaken the first performance for a mockery of their own defeat by the gods. The commentary on these verses contains many of Abhinavagupta's reflections on the status of fiction in art. A full translation of these passages is available in Cuneo 2008-20091. A translation of ABh ad Nś 1.107 appears as Appendix I in Gnoli 1968, and a portion of it in Pollock 2016: 218-222 (On the Nature of Dramatic Acting). A new French translation and critical edition of the totality of the first chapter is currently under preparation as a collaborative project of the present author with Lyne Bansat-Boudon and Daniele Cuneo. 
account fails to differentiate the process by which an onlooker or a spectator cognizes an emotion in real life and in theatre. ${ }^{107}$ Although Śankkuka ascribes a special power to poetic language, as a matter of fact, his theory of rasa as an imitated emotion requires an actor (the anukartr) as the locus of the display of the inferential signs of the character's emotion (the anukärya), which ultimately seems to confine the communication of emotions to gestures and other visible behaviours. This echoes the communis opinio, mentioned in the previous section, by which abhinaya works as a synonym of gesticulation (ceștā) as a means of knowledge based on inference that encompasses worldly and theatrical gestures alike.

Abhinavagupta, on the contrary, is adamant when he says that dramatic acting (abhinaya) - a function proper to theatre and distinct from imitationdoes not work through inferential signs, or through convention like ordinary language. The explanation of the functioning of abhinaya in epistemological terms is provided in his commentary on what is commonly regarded as the definition of theatre, i.e. Nś $1.119,{ }^{108}$ where abhinaya is the very means by which theatre, and the emotions embedded in it, become an object of cognition for the spectators:

In this way, how can such an object defined as theatre (nātya) enter the field of cognition? [In reply to this question, Bharata] says: [when it is conveyed by] the bodily and the other (angādi) [means of dramatic enactment]. The enactments, such as the bodily and so on, cannot be assimilated to inferential signs (linga) or to linguistic convention (sanketa). On the contrary, they are akin to an immediate direct perception (pratya$k s \underline{a s a}$ ăkșätkärakalpa). $†$ The entity defined as theatre does not $\dagger$ consist in worldly knowledge and so on, [to be established as] true or false. Its essence is indeed the [rasas] such as the amorous one (śringa ara) and others, which are instrumental to the cognition coinciding with a relishing, different from that of [states of] delight and so forth. Precisely because they are causal in bringing (nayana) [the meanings] directly in front $\left(a b h i m u k y a^{\circ}\right)$ [of the spectators], they are technically designated by the word abhinaya ('enactment', 'dramatic representation'), unknown

107 Abhinavagupta expresses this idea in ABh ad rasasūtra, vol. 1, p. 278: laukikacittavrttyanumāne kā rasatā? tenālaukikacamatkārātmā rasāsvādah smrtyanumānalaukikasamvvedanavilakșana eva. 'Where is the relish in inferring a worldly mental state? Therefore, the savouring of rasa, consisting in a super-mundane rapture, is absolutely different from worldly forms of awareness such as memory or inference'.

108 See above, $\S 3.2$, n. 39 . 
with this meaning in the śästra (i.e. Veda), in the world (i.e. in ordinary discourse), or elsewhere. ${ }^{109}$

In this passage, Abhinavagupta asserts the deep and irreducible distinction between the functioning of aesthetic communication and ordinary communication. The special cognition derived from abhinaya is not of a worldly order, since it transgresses ordinary experience, where cognitions are qualified as true, false, or doubtful. To emphasize its extraordinariness, the cognition resulting from dramatic representation is defined as similar-but not identicalto a direct perception, which will become a leitmotiv throughout the Abhinavabhäratī. The special status of abhinaya in theatre, as endowed with the directness of perception, sets aesthetic communication apart from the abhinaya known from other knowledge systems with the non-technical sense of gesticulation (ceșta $\bar{a})$, as well as from the speculation on gestures and linguistic convention in the sphere of grammar. ${ }^{110}$ At the same time, since abhinaya is conceptualized in the dramatic tradition as a blend of voice, body, mindfulness, and costume, its mechanism cannot be conflated with that of poetic suggestion, which works exclusively through language. Thus Abhinavagupta conceives the vocal enactment as twofold, since it cannot be reduced to the literary text disjoined from its vocal rendering by an actor, which includes aspects of prosody and melody as well. ${ }^{111}$

109 ABh ad Nś 1.119, vol. 1, p. 44: evaṃbhūto $\left[\mathrm{M}_{1}^{\text {ac }} \mathrm{T}_{1}^{\mathrm{ka}} \mathrm{T}_{5} \mathrm{~T}_{6} \mathrm{~T}_{7} \mathrm{E}_{1(2)}{ }^{\mathrm{pc}} \mathrm{E}_{1(4)}\right)^{\mathrm{pc}}$, evaṃ dayāratyādirūpānusaranabhūto $\mathrm{M}_{1}{ }^{\mathrm{pc}} \mathrm{T}_{1} \mathrm{E}_{1(2)}{ }^{\text {ac }} \mathrm{E}_{1(4)}$ ac, evam mayā ratyādirūpānusaranạhūto $\mathrm{E}_{1(1)}$ ] nātyalakșaṇo 'rthaḥ katham pratītigocarībhavatīty āha - añgādīti.ye 'bhinayāhn āngikāda-

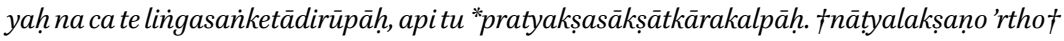
'laukikasamyañmithyājñānādirūpah [conj., pratyakșasākșātkārakalpalaukika ${ }^{\circ} \mathrm{M}_{1} \mathrm{~T}_{1} \mathrm{~T}_{5} \mathrm{~T}_{6}$ $\mathrm{E}_{1}$, pratyakșasākșātkārakalpyalaukika ${ }^{\circ} \mathrm{T}_{1}{ }^{\mathrm{ka}} \mathrm{T}_{7}$, pratyakșasākșātkārakalpā pratītị̆. ato na laukika $\left.{ }^{\circ} \mathrm{E}_{2}\right]$ tasyaiva bhāvah $\left[\mathrm{M}_{1}\right.$, bhāvāhh $\left.\Sigma_{\mathrm{M}} \Sigma_{\mathrm{E}}\right]$ śrnggārādayo ratyādivilakșaṇāsvādaparyāyapratītyupayoginaḥ. ata evābhimukhyanayanahetutvād anyalokaśāstrāprasiddhenābhinayaśabdena vyapadeśyăh. My translation is based on the text of the ongoing critical edition of the first chapter of the $\mathrm{ABh}$, which requires a conjecture in order to make sense of the text.

110 The reference to the workings of language by the use of the word sanketa in the passage under discussion is made clear by a parallel expression used to describe the process of dramatic communication in the sixth chapter (rasasütra, section on the obstacles, vol. 1, p. 275): abhinayanam hi saśabdalingavyāpāravisadṛ́am eva pratyakșavyāpārakalpam iti niśceșyāmaḥ. 'Dramatic acting, in fact, is different from the operation of inferential signs or words, as it is similar to the operation of perception. We will ascertain this later on'. This is possibly a reference to the lost Abhinavabhāratī on Nś chapter 8 .

111 From this perspective, the statement in Nś 14.2ab-vāci yatnas tu kartavyo nātyasyaișā tanuh smrtā |'An effort should be made in the verbal [component], for this is known to be the body of theatre' - is interpreted by the commentator as referring to the twofold effort 
Although rasa had clearly been conceptualized since Ānandavardhana's time as the domain of the literary text, which became a prerogative of every $k \bar{a} r y a$, it appears that Abhinavagupta considered the performative dimension as absolutely primary for the production of rasa in theatre. The first one to express this idea in clear terms was possibly Bhatța Tauta, according to whom the experience of rasa in theatre is paradigmatic and definitional, and cannot but be achieved through the staged performance of the poetic text. However, rasa can also be found in poetry to the extent that poetry behaves like a theatrical performance (nātyāyamāna) - in other words, when it gives rise to an especially vivid awareness that is similar to a direct perception (pratyaksakalpasamvedana). And this is exactly what abhinaya is bound to achieve in theatre. ${ }^{112}$ As we will see in the next section, if the purpose of dramatic acting is to convey the meanings of the poetic text in a lifelike manner that cannot be mistaken for an imitation, the discourse on aesthetic communication also takes into account-possibly for the first time, with Abhinavaguptathose aspects of non-verbal communication less directly connected with the play's text and proper to the specific spectacular format of dramatic performances, including singing and dancing. At given times in the performance of a play, music and dancing can in fact assume a particularly prominent role and appear as inextricably intertwined with a text and its enactment. The presence of such spectacular elements in the performance of a play is taken by Bhatta Tauta/Abhinavagupta as an argument against the interpretation of rasa as the imitation of a stable state and of theatre as an imitation in general:

required by the poet and the actor in vācikäbhinaya. Cf. ABh ad Nś 14.2ab, vol. 2, p. 220: vāci yatnas tu kartarya iti kavinā nirmānakāle națena prayogakāle: 'An effort in the verbal [component] should be made by the poet at the time of the composition [of the dramatic text], [and] by the actor at the time of [its] performance'.

$112 \mathrm{ABh}$ ad 6.33, vol. 1, pp. 284-285: nātyāt samudāyarūpād rasāḥ. yadi vā nātyam eva rasāh. rasasamudāyo hi nātyam. nātya eva ca rasāḥ. kārye 'pi nātyāyamāna eva rasaḥ. kāryārthavișaye hi pratyakșakalpasaṃvedanodaye rasodaya ity upādhyāyāh. yad āhuḥ kāryakautuke: 'prayogatvam anāpanne kāvye nāsvādasaṃbhavah |' iti 'varṇanotkalitā bhogaprauḍhoktyā samyag arpitāḥ | udyānakāntācandrādyā bhāvāh pratyakșavat sphuțāh ||' iti. '[The compound nātyarasāh can be interpreted as:] "the rasas arising from theatre", which is a composite entity. Or, as "the rasas that are theatre", for theatre is indeed a collection of rasas. Moreover, the rasas are found in theatre alone. Yet rasa is also found in poetry to the extent that it behaves like theatre. For according to my master [Bhața Tauta], the rasa arises when an awareness similar to a direct perception arises with respect to the content of a literary text. As he stated in the Käryakautuka: "As long as a poem does not reach the status of a performance, it is not possible to savour [it]. When factors such as a garden, a beloved woman, the moon, etc. appearing in a [poetic] description are properly conveyed by a verbal expression fully developed with enjoyment, they become as vivid as if they were directly perceived"'. 
Contrary [to the opinion that rasa is the imitation of a stable state, which can be inferred by the display of its external signs], [Bharata's] illustrations [of the rasas] etc., enlivened by the dhruva a songs, the variety of rhythms and the lāsyāngas, is rather a sign to the opposite. ${ }^{113}$

Echoes of a discussion about the imitative value of songs and music in theatre are also found in the first chapter, again within the general critique of theatre as an imitation:

Moreover, since [theatre] is no imitation, then even the objection raised by some [against theatrical extravagance and the lack of similitude]namely that nobody can be imitated as accompanied by songs and instrumental music in all situations - has no place. For we did not say that songs and the like [in theatre] are objects of imitation. Besides, a counterobjection to this has been voiced as follows: 'in the world, vocal and instrumental music are commonly encountered during activities such as sitting, walking, bathing, sleeping, awakening, eating, and so forth[, therefore the musical accompaniment in theatre imitates those].'This is untenable too, for in the world we do not find vocal and [instrumental music] in the form of dhruvās, rhythms, etc.[, proper to theatre,] in [association with] activities such as walking and so forth, with the sole exception of auspicious [occasions]. And [the imitative value of music in theatre is also untenable] because the very idea of imitation does not logically hold also with regard to such actions as singing, playing instruments, etc. That is all. ${ }^{114}$

113 ABh ad Nś rasasūtra (refutation of Śrī Śan̉kuka by Bhațța Tauta), vol. 1, p. 27o: pratyuta dhruvāgānatālavaicitryalāsyāngopaj̄̄vanam nirūpaṇādi viparyaye lingam. Gnoli (1968: 40) translates lāsyānga as 'sub-divisions of women's dance', and Pollock (2016: 186) as 'components of the preliminary dance', which cannot be the case here, since the context is the performance of drama and not the preliminary rite. An essential difference between the two types of lāsyāngas described in chapter 19 (the lāsyāngas of the play) and in chapter 31 (the lāsyāngas of the pürvaranga) has been clearly established by Lyne Bansat-Boudon (cf. § 2.1, n. 30 and 2.3 .1 ).

114 ABh ad 1.107, vol. 1, p. 38: yataś cedaṃ nānukaraṇaṃ tato yat kaiścic coditam tad anavakāśam-'na ca gītavādyayuktah sarvāvasthāsu kaścid anukāryaḥ' iti. na hy $\left[\Sigma_{\mathrm{M}} \mathrm{E}_{1(1)}\right.$, tv $\mathrm{M}_{1}$ $\left.\mathrm{T}_{1}{ }^{\text {ga }} \mathrm{E}_{1(1)}{ }^{\mathrm{vl}} \Sigma_{\mathrm{E}}\right]$ anukāryatvena gìtādaya ity uktam. parihāro 'piya uktah ${ }^{\prime *} \bar{a}$ sanagamanasnā $\overline{-}$ nasvāpapratibodhabhojanādyāsu vastuto $\left[\mathrm{E}_{1(4)},{ }^{\circ} \bar{a} d y a \bar{s} u\right.$ vastumāsu $\mathrm{M}_{1}{ }^{\mathrm{pc}},{ }^{\circ} \bar{a} d y a \bar{s} u(. .). m \bar{a} s u$

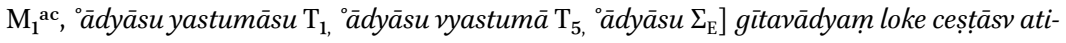
prathitam' ityādi, tad apy anupapannam. na hi gamanādau taddhruvātālādirūpeṇa gìtādi loke 'sti mañgalamātratvād ṛte. gāyanavādanādișv api cānukārabuddhyāpatter ity alam. My translation and understanding of this passage are based on the ongoing critical edi- 
This passage establishes an important difference between the use of music in theatre and in the world. In the world, playing instruments or singing songs can be performed in connection with other actions for the sake of auspiciousness, i.e. in ritual contexts. In theatre, although playing and singing are seen in connection with the enactment of some dramatic situation, they should not be considered as either the imitation of music played in connection with real-world events, nor as imitating anything in particular. They are a part of aesthetic communication on a par with enactment, but they are further removed from an external referent and hence from imitation because of their nonmimetic nature. As we shall shortly see, such spectacular elements that do not imitate anything are not just accessory elements, but are integral to the very idea of the fabrication of dramatic fiction and its educational goal.

To sum up, abhinaya can neither be equated with simple gesticulation, nor with the capacity of poetic language alone. On the contrary, it is a peculiar way of representing things on stage, involving the four means of the body, voice, mind, and costume, plus an array of non-semantic elements. As such, it must be distinguished from the mimicry of other people's behaviours and emotions, both in epistemological and in phenomenological terms. If abhinaya were to coincide with an imitation recognized as such, it would turn out as a parody, while if imitation were so perfectly achieved as to create a sense of illusion, it would be impossible to properly account for the cognition of theatre and its content as different from reality. The special status Abhinavagupta assignes to the cognition resulting from dramatic enactment, as a quasi- or simili-perception (pratyakșasākșātkārakalpa-pratīti), pleads for a nuanced interpretation of his rejection of anukaranavāda, where there is no absolute denial that theatre has any mimetic relation whatsoever to the world, but rather a re-qualification of dramatic representation and its object. As will be shown in the next sections, this re-qualification entails an even stricter mimetic connection between the actor, the enactment, and the enacted thing or character, which is exploited to distinguish theatre from the new genres of danced poetry or narrative dance. ${ }^{115}$

tion and translation of the first chapter of the ABh. The passage is translated differently in Cuneo 2008-20091: 206, and omitted both in Gnoli's and Pollock's translations of ABh ad Nś 1.107 .

115 This distinction will be treated in detail below, in $\S 3.5$, and constitutes one of the foci of the discussion of the nature of dance in the passage from the fourth chapter as edited and translated in this book. 


\subsection{Dance, Beauty, and the Fabrication of Dramatic Fiction}

śobhāpradhānam hi nātye sarvam (ABh ad Nś 1.121, vol. 1, p. 45)

The famous dictum that scripture instructs like a master, history like a friend, and poetry like a lover appears time and again in discussions on literary genres in poetic treatises. Such a neat threefold distinction in the didactic modes of operation of different textual types was popularized through the writings of Abhinavagupta. ${ }^{116}$ Although not expressed in the form of a maxim, the peculiar capacity of poetry to instruct and delight at the same time was already present in nuce in Bharata's treatise, ${ }^{117}$ as well as in some of the first non-systematic discussions about the function of literature embedded in literary works, famously in Aśvaghoșa's second-century poems. ${ }^{118}$ From a discourse used to justify the beginnings of a new genre in Sanskrit with didactic aspirations, the pleasurable experience ascribed to literature crystallized, in the works of literary critics, into a debate about the double purpose of art: pleasure (priti $i$ ) and instruction (vyutpatti).119

116 As Pollock (2016: 31; 152; 369, n. 28; 371, n. 59) remarks, the division existed even earlier and was possibly inaugurated by Bhațta Nāyaka. The textual locus of this attribution is a fragment of Bhațta Nāyaka in DhvĀL, p. 39 (ibid. 149, \#7).

117 Notably, at the beginning of the treatise, when the gods ask Bhramā for an object of diversion, a krị̈anīyaka (Nś 1.11c), which is at the same time an instrument of moral instruction, the Fifth Veda (Nś 1.12); for other passages suggesting such a twofold purpose of theatre, see Cuneo 2015: 75 .

118 The image of the bitter medicine coated in honey is used at the end of the Saundarananda as a metaphor for the teachings imparted by poetry. Saundarananda 18.63: ity eșā vyupaśāntaye na rataye mokșārthagarbhā krtih | śrotṝnām grahanārtham anyamanasām kāryopacārāt krtā || yan mokșāt krtam anyad atra hi mayā tat kāryadharmāt krtam | pātum tiktam ivāuṣadham madhuyutạ̣ hṛdyam katham syād iti || 'This composition on the subject of liberation is for calming the reader, not for his pleasure. It is fashioned out of the medicine of poetry with the intention of capturing an audience whose minds are on other things. Thinking how it could be made pleasant, I have handled in it things other than liberation, things introduced due to the character of poetry, as bitter medicine is mixed with honey' (translation Covill 2007: 363). See also Buddhacarita 28.74. The metaphor of poetry as the sweet honey allowing people to swallow the bitter remedy was taken up by Bhāmaha in the seventh-century. Kāryālaṃkāra 5.3 reads: svādukāryarasonmiśraṃ śāstram apy upayuñjate | prathamālị̀hamadhavah pibanti kațu bheșajam || 'One would use even a scientific treatise, provided it is mixed with the sweet flavour of poetry. Those who have first licked honey, drink the bitter medicine.'

119 On the development of this debate and on the priority assigned to either purpose by literary theorists, see for instance Cuneo 2015 . 
Given the predominantly courtly production of poetry in the classical and medieval periods, poetry was conceived — at least in theory, but probably also in practice-as an art to be consumed in the elite, restricted circle of literary connoisseurs. ${ }^{120}$ Theatre, on the contrary, seems to have enjoyed a larger audience from the beginning, given the diversity of occasions for the performance of drama besides the royal sabha ${ }^{121}$ At least in theory, drama was presented as an art whose ambition was to reach out to all levels of Indian society, irrespective of caste affiliation and including even those strata of the population less exposed to Sanskrit education, i.e. women, children, and the feeble-minded (strïbälamürkha ${ }^{\circ}$, as Nś 34.222 puts it). This capacity to affect larger audiences, which delineates theatre from poetry, was contingent on its spectacular dimension, a fact that was already stressed by Bhațta Tauta in his Käryakautuka. ${ }^{122}$ But establishing what exactly singles out the pleasure provided by the performance of a play from the one provided by the recitation of a poem, the reading of an epic text, a solo dance recital, or a musical performance, is Abhinavagupta's original contribution to the field of aesthetics. His fine analysis relies on an

120 Abhinavagupta's remarks about the need of poetry for the instruction of the royalty, in DhvĀL 3.10-14, p. 336, are revealing in this regard: iha prabhusammitebhyah śrutismrtiprabhrtibhyaḥ kartavyam idam ity ājñāmātraparamārthebhyah śāstrebhyo ye na vyutpannāh, na cāpy asyedạ̣ vṛttam amușmāt karmaṇa ity evam yuktiyuktakarmaphalasaṃbandhaprakațanakārikebhyo mitrasammitebhya itihāsaśāstrebhyo labdhavyutpattayah, atha cāvaśyaṃ vyutpādyāḥ prajārthasaṃpādanayogyatākrāntā rājaputraprāyās teșā̄m hṛdayānupraveśamukhena caturvargopāyavyutpattir ādheyā. hrdayānupraveśaś ca rasāsvādamaya eva. 'Princes, who are not educated in scripture-those works of śruti, smrti, etc. which consist in commands, like those of a master, to do this or that - and who have not received instruction from history, which like a friend reveals to us the connection of cause and effect as endowed with reasoning, such as "this result came from such an act", and who are therefore in pressing need of instruction, for they are given the power to accomplish the wants of their subjects, can be given instruction in the four goals of man only by entering into their hearts. And what enters into the heart is the relish of rasa (rasāsvāda)' (translation based on Ingalls et al. 1990: 437).

121 Festivals, whether religious or not, were also typical occasions for the staging of Sanskrit drama, as many of the prologues of the extant plays indicate. The historical evidence about the staging of Harșa's seventh-century plays, collected in Bakker 2014, suggests that theatrical performances were primarily public events, attended by royals and citizens alike.

122 See above, n. 112, for Bhatța Tauta's quotation on the importance of prayoga. As Abhinavagupta explains on several occasions, the accessibility of the instruction (vyutpatti, upadeśa) given by theatre about the right means for obtaining the four aims of mankind is linked to its character of being similar to a directly experienced reality. While watching a play, in fact, a spectator sees the display of actions connected with their results, and thus receives an ethical teaching on how to behave like Rāma to obtain good results, and unlike Ravvana to avoid bad ones. For an elaboration on the connection between drama and dharma (and the other aims of man), see Bansat-Boudon 2001. 
essential distinction among the elements participating in the aesthetic process into those that serve the communication of specific textual meanings and those that merely provide pleasure. This distinction could be conceptualized, in terms of functionality, as one between semiotic elements and, to borrow a term well established in classical studies, psychagogic ones. ${ }^{123}$ Moreover, Abhinavagupta pays utmost attention to how these two kinds of elements interact with one another at different times in a performance, and to how they merge, as it were, into one another in the fabrication of the fictional object. This object, it is worth reminding, aims at the arousal of rasa for the totality of the spectators and in its twofold dimension of pleasure and instruction.

\subsubsection{On the Psychagogic Power of Dance}

As hinted above, dramatic acting in its four registers guarantees an especially vivid cognition of the contents of the literary text, by which all spectators see things as if they were taking place directly in front of their eyes. Only connoisseurs, however, intended as individuals especially gifted with aesthetic sensibility and imagination, are believed to be able to experience the rasa merely by reading or hearing a poem, or by having a drama read out, and not enacted. According to Abhinavagupta, such individuals are endowed with a heart especially similar to a spotless mirror, since their mind is not guided by desire, confusion, or anger, which characterize the human condition. Due to this special quality, they may obtain a vivid cognition of the content of literature and sympathize with the emotional core of a poem, or get to taste the various rasas of the text of a drama that is simply read out. ${ }^{124}$ Those who are not susceptible to poetry, on the contrary, depend on the actors and the means of dramatic

123 I use the term psychagogy (and the adjective psychagogic derived from it) in the Hellenistic sense of an aesthetic principle that singles out the function of art as the 'leading of the soul', connoting 'pure entertainment' (also 'enchantment') as opposed to 'instruction' (Zanker 2015: 63). The idea, used to designate the function of music in antiquity but extending to other arts as well, especially in the Hellenistic period, is that art should 'lead or persuade the spirit' into aesthetic pleasure (ibid.: 67 ).

124 ABh ad Nś 6.33, vol. 1, p. 285: hrrdayasamvvādatāratamyāpekșayā śrotrpratipattrisphuranam sphuțāsphuțatvenātivicitram. tatra ye svabhāvato nirmalamukurahrdayās tata eva samsārocitakrodhamohābhilāṣaparavaśamanaso na bhavanti teșām tathāvidhadaśarūpakākarṇanasamaye sādhāraṇarasanätmakacarvaṇagrāhyo rasasañcayo nātyalakșaṇah sphuța eva. 'Now, given the varying degree of their heart's concurrence, those who hear a reading or watch a play can have a highly differentiated appreciation, depending on its clarity or obscurity to them. Someone whose heart is by nature like a spotless mirror has, for that very reason, a mind no longer subjected to the anger, confusion, craving, and so on typical of this phenomenal world; for such a person, on the occasion of hearing a play with its various appropriate components, the cluster of rasas-the defining feature of 
enactment for achieving a vividness of the cognition and experiencing the depicted events more directly. ${ }^{125}$ Key terms recurring as a leitmotif in Abhinavagupta's explanation of the distinctive perception of theatre achieved by means of the fourfold enactment (abhinaya) are the aforementioned pratyakșasākșātkārakalpapratīti, the loosely synonymous pratyakșakalpasamvedana, sphuțādhyavasāya, sākșātkārakalpānuryavasāya, and so on. ${ }^{126}$

In order to untie the knots in the hearts of those spectators who are still prey to their own passions so that they might become absorbed in the events represented, Abhinavagupta recommends pleasant activities such as singing, instrumental playing, and the like. ${ }^{127}$ Key words in this connection are (upa)ra$\tilde{n}$ jana $\bar{a}$, *hrdayahärana, etc., all having to do with notions of entertainment, beauty, charm, and allurement, typically assigned to a group of elements said to be entertaining (uparañjaka, lit. 'colouring') or charming (hrdya, lit. 'hearty'). These typically include vocal music, instrumental music, and dance, performed alone or in combination. The role played by the charming elements in purifying the still opaque heart of the spectators so as to enable an aesthetic experience even for the least aesthetically endowed individuals is best illustrated in the following passage from the rasasütra. The passage contains an explanation as to how to get rid of one of the main obstacles hindering the cognition of rasa (the third obstacle), lying in the fact that a spectator may be overwhelmed by his own worldly concerns and find it difficult to concentrate on another object: ${ }^{128}$

drama - will be entirely clear and cognized by a relishing that is essentially a tasting of their commonality' (translation Pollock 2016: 209).

125 ABh ad Nś 6.33, vol. 1, p. 285: ye tv atathābhütās teșām pratyakṣocitatathāvidhacarvanāà $\bar{a}-$ bhāya națädiprakriyā. 'Someone else, by contrast, who lacks these traits will require the procedures of actors and the rest of stagecraft in order to attain that sort of perception-like relishing' (translation Pollock 2016: 209).

126 On anuryavasāya, see below, n. 164, and Translation, n. 140.

127 ABh ad Nś 6.33, vol. 1, p. 285: [...] svagatakrodhaśokādisañkațahrdayagranthibhañjanāya gìtādiprakriyā ca muninā viracitā. sarvānugrāhakam hi śāstram iti nyāyāt. '[...] for such a person the sage - on the maxim that a work of systematic thought must seek to fulfil everyone's needs - has made further provision in the procedures of singing and so on, to loosen the knot of the viewer's heart, hardened as it is by the anger, grief, and so on he bears inside' (translation Pollock 2016: 209). See also, at the end of the rasasütra (vol. 1, p. 281), Abhinavagupta's statements on music and dancing as means to purify the hearts of even insensitive spectators: ahrrdayānām ca tad eva nairmalyādhāyi.yatra pratītā gìtavādyagaṇikādayo na vyasanitāyai paryavasyanti nātyopalakṣaṇāt. 'But for those lacking in receptivity, drama alone can produce such clarity, because it is only there that the apprehension of singing, music, and the courtesan actresses does not lead to vicious behavior, since they are simply features of drama' (translation ibid.: 204).

128 Gnoli (1968: xli, n. 1) described these 'obstacles' in the following way: 'The vighna, ob- 
Moreover, how could someone who is under the sway of his own pleasure[, pain, or indifference] make his consciousness rest on another object? In order to remove such an impediment, [Bharata] has resorted to the charm (uparañjana) of vocal and instrumental music, well-adorned playhouses, courtesans skilful in eloquence, and so on. These [charming elements], made of vocal objects and the like, residing in all the different components [of the performance], are liable to be enjoyed by all the [spectators] thanks to their power of generality (sādhäranya). Thanks to this ['colouring'], even a person devoid of any sensibility is turned into a connoisseur by obtaining a limpidity of the heart. In fact, it has been said that [this theatre must be] 'visible and audible (Nś 1.11d)' [i.e. pleasing and instructing]. ${ }^{129}$

Turning the spectator into a connoisseur, a sahrdaya (lit. 'endowed with heart'), is indeed what the charming elements are supposed to effectuate during a theatrical performance. This coincides with a cleansing of the heart of all possible distracting and obstructing mental states, which is a prerequisite for being aesthetically touched by the performance. This 'aesthetic susceptibility' (Rastogi 2016: 142), proper to sahrdayas, was initially described by literary critics as the capacity to appreciate poetry. ${ }^{130}$ Abhinavagupta's famous definition of the 'ideal connoisseur' in the Locana states that sahrdayas are 'persons who are capable of identifying with the subject matter, as the mirror of their hearts has been polished by the constant study and practice of poetry, and who respond

stacles, are all the extraneous elements which break the unity of a state of consciousness (desire for gain, worry of all kinds, etc.).'

$129 \mathrm{ABh}$ ad rasasūtra (section on the hindrances), vol. 1, p. 275: nijasukhādivivaśíbhūtaś ca katham vastvantare samvidam viśrāmayed iti tatpratyūhavyapohanāya pratipadārthanișthaị̣ sādhāranyamahimnā sakalabhogyatvasahișnubhị̣ śabdādivișayamayair ātodyagānavicitramaṇdapapadavidagdhagaṇikādibhir uparañjanam samāśritam. yenāhṛdayo 'pi hrrdayavaimalyaprāptyā sahṛdayīkriyate. uktam hi 'drśyam śravyam ca' iti (translation based on Cuneo 2008-20091:292-293). I understand sādhäranyamahiman- as strictly connected to the process of sādhäranīkarana or generalization, in that the charming elements transform the experience of the viewer and thus allow the suppression of the usual references of the cognition to one's own limited experience. On sādhärañikaraṇa, see below, n. 167 and 173. Priti i and vyutpatti are to be read in filigree under the 'visible and audible nature of theatre', as declared in ABh ad Nś 1.11d, vol. 1, p. 12: drśyam iti hrdyam śraryam iti vyutpattipradam iti prītiryutpattidam ity arthah.

130 In one of the earliest uses, Vāmana wrote that a certain poetic style known for its excel-

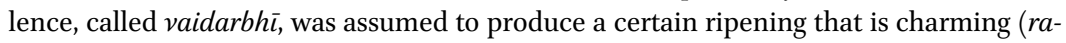
ñjaka) to the hearts of sahrdayas. See Kāryālaṃkārasūtravrtti ad 1.2.21, quoted in Smith 1985: 46: sahṛdayahrdayānāṃ rañjakaḥ ko 'pi pākah. 
to it sympathetically in their own hearts.' ${ }^{131}$ Similarly, in the Abhinavabha $\bar{a}$ ratī, Abhinavagupta attributes the capacity to appreciate poetry independently of stage presentation to those who are already connoisseurs thanks to the repeated practice of poetry, previous merit, and so forth: for them, 'heard' rasa can be the object of a quasi-direct perception. ${ }^{132}$ Whereas poetry is produced by sahrdayas and for sahrdayas, theatre has to appeal to everybody by developing one's aesthetic susceptibility. Turned into a sahrdaya thanks to the special charm brought forward by some of its spectacular elements, the spectator will be able to sympathetically respond to the events represented and access the rasa, and through it the twofold goal of theatre, pleasure and instruction.

A concrete example of how the charming elements operate in a theatrical performance is seen in the use of the gorgeous manner (kaisikivrtti). With regard to its introduction into the performance, Abhinavagupta voices the idea that although the meanings may be vividly expressed through the enactment, charm or beauty are required in order to access the rasa. The kaisikik, containing elements of dance as well as instrumental and vocal music, is said to be a supporting element of the performance (upakarana); yet it is not just an accessory item, but is defined more than once as the vital essence of the performance (sakalaprayogaprāna). ${ }^{133}$ Abhinavagupta describes the kaisikì as a 'heartcatching multifariousness' (hrdayahāri vaicitryam), ${ }^{134}$ necessary for the manifestation not only of śrngāra rasa - quite intuitively enhanced by beautiful elements such as dances and songs - but of all the other rasas too. Without such a beautiful multifariousness, he argues, the performance would not appeal to the spectators, and the dramatic representation would remain completely unintel-

131 DhvĀL 1.1, pp. 38-39: yeșāṃ kāryānuśillanābhyāsavaśäd viśadībhūte manomukure varṇanōyatanmaȳ̄bhavanayogyatā te svahṛdayasaṃvādabhājah sahṛdayāḥ (translation Ingalls et al. 1990: 70).

132 ABh ad rasasūtra, vol. 1, p. 281: tena ye kāryābhyāsaprāktanapunyādihetubalādibhị̣ sahrdayās teșām parimitavibhāvādyunmīlane 'pi parisphuța eva sākșātkārakalpạ̣ kāryārthạ̣ sphurati. ata eva teșām kāryam eva prîtivyutpattikṛ anapekșitanātyam api. 'Thus, for those who are receptive readers thanks to, among other things, their study of literature and their good karma from past lives, the "aim of a literary text" manifests itself with absolute clarity, as if before their very eyes, even when only a limited number of aesthetic elements is disclosed. And hence for them, literature alone, without any reference to dramatic spectacle, can bring at once pleasure and instruction' (translation Pollock 2016: 204).

133 Cf. avataraṇikā ad Nś 1.41, vol. 1, p. 20: atha sakalaprayogaprānabhūtakaisikyupayujyamānopakaraṇāntarasaṃharaṇāyopakramaṃ darśayati bhāratīm ityādi; $\mathrm{ABh}$ ad Nś 4.5, vol. 1, p. 86: evam itihāsasya parisamāptim paśyan sakalaprayogaprānabhūtakaiśikisarvasvabhūtantttaprayogaprastāvanāyetihāsam anusandhatte.

134 ABh ad Nś 1.44, vol. 1, p. 21: etanmadhye hṛdayahāri vaicitryam yojanīyam iti. 'a heartcatching multifariousness should be employed among these [other manners].' 
ligible or barely accessible, which would invalidate the manifestation of rasa, jeopardizing all efforts towards a lifelike representation:

However, how would the [kaisikī] be useful in theatre? [...] From the [gorgeous manner] springs the amorous rasa taught in theatre, not in any other manner. [...] Therefore, if one employs the enactment, even if fourfold and delicate (sukumāra), as a means to manifest the amorous rasa, without sweet and indolent spins and whirls, without frowns of the eyebrows, sidelong glances, etc., one cannot even mention the relishing of śrngāra rasa[, let alone experience it!] [...] Even if one has to bring about the manifestation of [other] rasas such as raudra and so on, the enactment employed cannot be the cause of the manifestation of rasa, insofar as it is hardly alluring or non-alluring if it is not commingled with the beautiful multifariousness [of the gorgeous manner,] consisting in alliterations, spins and whirls, and the like. Therefore, in every possible case [i.e. for every rasa], the gorgeous (kaisiki $)$ [manner] is the vital essence [of the performance]. This is what Bharata will say in Nś 8.14: 'The śäkhā, dance (nrtta), and the ankura [should be known here by practitioners] as the elements of this [bodily] acting (abhinaya)'. Therefore, without the [kaiśikī one cannot even mention the name of śrngārarasa. ${ }^{135}$

Such remarks about the necessity to use the kaisiki alongside the acting for the sake of every rasa, be it the amorous or the furious, can be read, I think, against the background of the function ascribed to the charming elements in theatre, which operate side by side with the enactment for enabling the experience of rasa. However, besides loosening the knots in the spectator's heart and preparing him for a cognitive immersion in the object of representation, this passage suggests that the beautifying elements have an effect on the enactment itself, with which they are closely intermingled. To be sure, it is sometimes difficult to clearly distinguish the charming elements from the means of dramatic enactment, since these two, though their function may be distinguished for the

135 ABh ad Nś 1.44-45, vol. 1, p. 22: nanu sā nātyopayoginī katham [...] tan nātyoktaśrningārarasaḥ saṃbhavati, nānyathā. [...] tena śrngāärābhiryaktihetau sukumāre caturvidhe 'py abhinaye yojite madhuramantharavalanāvartanābhrūkșepakațākșādinā vinā śrngāararasāsvādasya nāmāpi na bhavati. [...] raudrādirasābhiryaktāov api kartavyāyām yo 'bhinaya upādīyate so 'py anuprāsavalanāvartanādyātmakasundaravaicitryasyāmiśranayā duḥślișto 'ślișta eva vā na rasābhivyaktihetur bhavatīi sarvatraiva kaiśikī prāṇāh. yad vakșyati'asya śākhā ca nrttam ca vastūny abhinayasya' iti șrnigārasasya tu nāmagrahaṇam api * tayā vinā na śakyam $\left[\Sigma_{\mathrm{M}}\right.$, na tayā vinā śakyam $\left.\Sigma_{\mathrm{E}}\right]$. Translation based on Cuneo 2008-20091: 171-172. Partially translated also in Bansat-Boudon 1992: 176-177, n. 509 and 517. 
sake of theory, are in practice not found in isolation. It suffices to think of the songs used in theatre, the so-called dhruvās which, besides featuring elements of melody, also contain meaningful lyrics; or dance, which may sometimes come very close to bodily acting. In the passage above, for instance, the 'sweet and indolent spins and whirls, frowns of the eyebrows, sidelong glances etc.' are movements common to the vocabulary of dance as well as to the $\bar{a} \dot{n} g i k \bar{a}-$ bhinaya. ${ }^{136}$ Moreover, the verse quoted by Abhinavagupta on this occasion in order to motivate the use of dance as part of the kaisikivrtti, and its consequent incorporation into the dramatic production, indicates that dance is an element of bodily acting (Nś 8.14ac: asya śākhã ca nrttam ca vastūny abhinayasya). Does this mean that, under certain conditions, dance can be used to communicate meaning, i.e. as bodily enactment?

The problem of grasping the specific purport of the charming elements alongside dramatic enactment, which allows for distinguishing the use of dance within theatre vis-à-vis bodily acting, is at the heart of Abhinavagupta's second interpretation of the purvapakșa in the passage translated in this book. ${ }^{137}$ The opponent, in fact, puts dance in the same category as instrumental and vocal music, arguing that these provide variety, entertainment, and beauty to the performance, all notions encompassed by the term uparañjaka. Nonetheless, he argues, one clearly sees that songs - typically of the dhruva typeare added in order to provide pieces of information about the type of character, his mood, and situation by supplying what is only implicit in the dramatic text. On the other hand, he continues, instrumental music is seen to enhance the rhythm, which is introduced for harmonizing the song. ${ }^{138}$ From this perspective, the opponent concludes, one cannot attribute any independent nature to dance, lest it end up being a form of bodily acting (ängikäbhinaya). Abhinavagupta's mordacious reply pins his opponent in a corner, revealing the fallacies of his argument: if songs be used only to supply information absent from the play's text, then the dhruvās may just as well be read out, and all the vocalists' singing efforts be dispensed with. ${ }^{139}$ The opponent's mistake lies indeed in confining the role of songs to their meaningful portion (the lyrics that are delivered through singing), which can easily be equated with a simple case of vocal enactment (vācikäbhinaya) that relies primarily on its semiotic value. However, semiotic elements (the text recitation) coexist with psychagogic ones

136 As remarked by Bansat-Boduon (1992: 176, n. 509), such movements as 'spins and whirls' (valan $\bar{a}-v \operatorname{artan} \bar{a})$ are especially found in dance and in the register of acting called śākhā.

137 See Edition and Translation 3.1-6.

138 See Edition and Translation 3.4.3.

139 See Edition and Translation 6.9.3. 
(the various tonal structures and vocal ornaments) in songs, and they are not always easy to disentangle. Moreover, the very presence of psychagogic elements differentiates singing from vocal acting. Similarly, dance can be mingled with bodily acting to various degrees, but should not be confused with it. ${ }^{140}$

Abhinavagupta compels the opponent to modify his position with regard to how the pleasurable elements in theatre help the audience grasp the meanings that are brought forward through the acting: by piercing the heart like a needle, pleasure enables the spectator to access the contents of the play and identify sympathetically with the characters, thereby learning which forms of conduct must be accepted and which should be rejected. ${ }^{141}$ This function of pleasure is evocative of the innate pedagogy of theatre, and literature more generally.

Now that a psychagogic function has been ascribed to the charming elements-distinct but complementary to the semiotic one ${ }^{142}$ proper to dramatic acting - the commentator proceeds to attribute another function to dance within dramatic performance, one that is specific to it. Before looking at the details, it might be useful to point out that a subtle nuance is at play here between the beauty characteristic of dance performed even outside theatre, out of sheer joy-for instance, Śiva's dance performed at dusk, the model evoked for the theatrical kaisiki - and the beauty of dance performed within a play, which is directed at charming the spectator. In itself, dance is described merely in terms of movements characterized by beauty, having no aim outside itself, unlike other purposeful actions. ${ }^{143}$ This amounts to saying that it is different both from the purposeful actions of the characters represented in theatre, whose model is clearly worldly, human action, and from theatre itself, which aims at instructing the audience in what to do and what to avoid in order to pursue an ethical life. However devoid of any aim or meaning outside itself, when it enters the complex object that is theatre, dance is put into its service, in particular by providing pleasure. It is the latter that I have dubbed the psychagogic power of dance, close to the function that the Greeks assigned to music in leading or persuading the soul to enjoy aesthetic pleasure.

140 As the title of a penetrating section in Bansat-Boudon's analysis of dance reads, 'Allier, mais ne confondre' ('Associate, but don't conflate') (2004: 193-198), one cannot avoid thinking of the necessary co-existence of the phenomenal and semiotic body in performance as theorized by Fischer-Lichte 2008: 82, and their relationship as being 'in constant flux' (Schlapbach 2018: 18).

141 See Edition and Translation 6.9.4.

142 As Bansat-Boudon (1994b: 195) says about the role of dance within theatre, 'indépendamment de la diversité des intrigues, elle ouvre au sens, par la beauté'.

143 See the definition of karana in $\S 2.2, \mathrm{n} .40$, and $\S 2.4$, n. 111 . 


\subsubsection{Like a Fire-Wheel: Dance and Fiction}

Besides its special power to charm the spectator, dance has also another, more specific use in theatre, which has much to do with the construction of fiction and its cognition by a spectator. Abhinavagupta expresses this function by means of two metaphors, the fire-wheel and the bracelet:

In particular, without [dance], theatre could not be mentally grasped by the [spectators] in the image of a fire-wheel (alätacakrapratimatve). For this very reason, dance-consisting of spinning, [whirling,] and the like-is similar to a thread (sütra) that joins together into a bracelet (gumpha) the clear rubies of abhinaya. Due to [its] proximity to [dance], [namely] the fact of being homogeneous [with it, since both display bodily movement], theatre encompasses the songs and the other [pleasurable elements] that are part [of it]. ${ }^{144}$

Of the two images evoked with regard to theatre, the alätacakra motive is not completely absent from the Nātyaśāstra, since it is found in a single occurrence in chapter 28 , at the beginning of the section on music. This is most certainly the source for its various uses by Abhinavagupta. Besides its theatrical uses, the example of the fire-wheel (alätacakra) produced by the quick rotation of a firebrand (aläta) has been extremely productive in the philosophical literature of South Asia, acquiring different shades of meaning in its various uses. It is moreover current already in the epics, with some of the connotations that will be proper to later philosophical uses, but also with meanings specific to them. ${ }^{145}$ Now, whereas the Nätyaśāstra is a text closer in date to the epics, Abhinavagupta's use of the alätacakra trope is rather marked by

144 ABh ad Nś 4.263cd-264ab, vol. 1, p. 178: viśeșato hi tadvinā 'ātacakrapratimatve tair buddhigrāhyam eva nātyam na syāt. tata eva vimalābhinayamāṇikyagumphavidhāyisūtrasthānìyam valanādirūpanrttasajātīyatvān nikațatvād antarañgagìtādivyāpi nātyam. See Edition 3.9.5. This passage was first brought to my attention in the French translation of Bansat-Boudon (1992: 403 and 62, n. 50). As I will clarify in what follows, my translation differs mainly in the interpretation of the compound 'alätacakrapratimatve'. In the French translation, it is interpreted as the reason for the impossibility to mentally grasp theatre, which, in the absence of dance, is bound to remain an alätacakra, i.e. a vortical but inaccessible spinning wheel: 'en effet, sans elle, il serait à l' image d' un cercle de feu (alätacakra) dont les (spectateurs) ne pourraient se saisir mentalement' (ibid.). On the contrary, I tend to read 'alätacakrapratimatve' as the conditio sine qua non for grasping theatre, which cannot be achieved without dance. Both translations are syntactically possible; the reasons for my privileging the second interpretation has to do with how I understand the peculiar use of the metaphor of the fire-wheel in theatre.

For references on early occurrences of alāta and alātacakra in philosophical contexts, see 
its later philosophical adaptations. Therefore, in order to properly grasp its connection with dance, it is necessary to proceed to a comparison of the use of the alätacakra trope in the theatrical field with its use in philosophical texts.

In NŚ 28.7, Bharata says:

In this way, theatre practitioners should make songs (gāna), music ( $v \bar{a} d y a)$, and drama (nātya) having different bases, similar to a fire-wheel (alātacakrapratima). ${ }^{146}$

This verse, found at the beginning of the section on music, immediately follows the description of the three ensembles (kutapa) responsible for a theatrical performance, which includes their configuration and arrangement on the stage. These are the ensemble of stringed instruments (tatakutapa), to which belong the vocalists, the vipañ $\bar{\imath}$ and viña players, and the flautist; the ensemble of percussionists (avanaddhakutapa), including the various drummers playing on the mrdanga, panava, and dardura; and the ensemble for enactment (nätyakutapa), including actors impersonating all classes of characters. ${ }^{147}$ The three basic elements singled out by Bharata in 28.7 as songs ( $g \bar{a} n a$ ), instrumental music ( $v \bar{a} d y a)$, and theatre (nātya) stand for the various means of expression appointed to these three different groups of practitioners. The first group, that of the singers, along with the players of stringed and wind instruments, is responsible for the melodic part. The second, to which the drummers belong, is responsible for the rhythmic part, and the last one, formed by the actors, is responsible for the enactment. Although distinct and belonging to separate artistic disciplines, in theatre these three groups should function interdepend-

Bouy 200o: $255^{-256}$ and Schmithausen 1965 , and for the epic background of some philosophical usages, see Fitzgerald 2012.

146 NŚ 28.7: evaṃ gānam ca vādyam ca nātyam ca vividhāśrayam | alātacakrapratimaṃ kartavyam nātyayoktrbhih $\|$

147 On the three kutapas, see Nś 28.3-6. A double semantic analysis is given to the word kutapa in the Abhinavabhāratī. See ABh ad Nś 2.72, vol. 1, p. 64: kur nätyabhümis tām tapati ujjvalayatīti krtvā. kutam śabdam pātīty anye. '[The word kutapa signifies] that which heats up (tapati) the earth $(k u)$, i.e. the theatrical stage. According to others, it is that which protects ( $p \bar{a} t i$ from root $p \bar{a}$; cf. DP 2.47) what resounds (kuta, from root $k u / k \bar{u}$, cf. DP 2.33), i.e. the sound.' Cf. also ABh ad Nś 5.17, vol. 1, p. 210: evaṃ kutam pāti kuṃ tapatīti śabdaviśeșapālakasya nātyabhūmikojjvalatādhāyinaś ca vargasya; $\mathrm{ABh}$ ad Nś 4.271: kutam śabdam pātīti caturvidham ātodyam kutapam tatprayoktrjātaṃ ca; ABh ad Nś 28.2, vol. 4, p. 2: kutạ̣ śabdam pāti, kum ca rañgam, tapaty ujjvalayati. 
ently and work in unison. While using the alätacakra image, Bharata must have had in mind the unification and harmonization of the performers of the multiple media used in theatre. However, he might also have used this specific image with a view to the cognitive act grasping the unity of the fire-circle, hence to the experience of spectators: after all, the circle is 'real' only insofar as it is perceived as a unitary image by an onlooker. As will be shown below, even in other contexts, the image of the alätacakra is invariably connected with the cognitive act grasping it.

While reflecting on Bharata's usage of the fire-wheel image, Abhinavagupta places it explicitly in the realm of cognition and focuses on the act of perceiving the alätacakra as a single image formed by the disparate elements of theatre. At the same time, he does not lose sight of its being the product of human activity, which requires an effort towards the harmonization of the different parts by theatre practitioners:

Since [theatre] is based on various [elements], i.e. has the form of various actions grasped by different organs of perception, its unity must be produced by [theatre practitioners] through an effort, by means of which it may become, for the spectators, the object of a single cognition. For in reality, a spark from the flame of a firebrand cannot be connected simultaneously with several points in space. However, just as [the fire-wheel] is brought to homogeneity through an effort [to achieve] speed, so too is the performance. For, similarly, [the performance] does not consist in one single action, but can be produced in the same way [as the fire-wheel] through an effort aimed at achieving a harmonization [of its different parts]. Therefore, [Bharata] says that this [theatrical performance] is 'similar to a fire-wheel.' ${ }^{148}$

The comparison of a theatrical performance with the image of the alätacakra here indicates the functioning of the various parts of theatre in dependence on one another, which allows the spectator to have a cognition of theatre as a single object. ${ }^{149}$ Not only should the three ensembles work together harmoni-

148 This is a tentative translation of ABh ad Nś 28.7 , vol. 4, p. 4, with some emendations to what appears to be a highly corrupt text: yasmād vividhäśrayam bhinnendriyagrāhyavividhakriyārūpam, tasmād yatnenāsyaikatā tatsampāadyā, yenaikabuddhivișayatā sāmājikasya gacchet. alātatejaḥkaṇo hi na vastuto yugapad anekadeśasaṃbandhī. läghavayatnena tu yathā (conj., tathātathā $\mathrm{E}_{1(4)}$ ) sāmyam āpāditam, evam prayogo 'pi. *tathā hi (conj., tath$\left.\bar{a} p i \mathrm{E}_{1(4)}\right)$ naikakriyātmā, sāmyāpādanāyayatnena (conj., ... tnena $\left.\mathrm{E}_{1(4)}\right)$ tu tathā saṃpādita ity etad āha 'alātacakrapratimam' iti.

149 In the fifth century, the grammarian Bhartrihari had already noticed the multimedial 
ously; each ensemble, forming a complex unity in itself, should be responsible for the harmonization of its peculiar medium of expression. The overarching principle governing their combination is a hierarchical arrangement in which enactment is the primary element, and the two musical ensembles are secondary elements that colour it. Abhinavagupta expresses this by way of an imaginary objection, in which the reader is reminded that the alätacakra image was already used by the commentator in the chapter on the sāmānyābhinaya or harmonious acting:150

An objection may be raised, [namely] that the fact [that the performance is similar to a fire-wheel] has already been stated in the chapter on the harmonious acting. True, but that was [said] with regard to the enactment, while here it concerns the mutual [combination] of vocal music, instrumental music, and acting. The objector might continue: but why have they been distinguished into three groups? Bharata removes this doubt by uttering the seventh verse (i.e. Nś 28.7). First of all, acting (nātya) is the element to be enhanced (uparañjanīya) [by vocal and instrumental music]. ${ }^{151}$ If one says that in harmonious acting (sāmānyābhinaya), one group (rāśi $)$ is brought to unison by force of the enactment,

nature of theatrical performance, pointing out that theatre is a complex and composite action involving different agents, cf. VP 2.373.

150 The alätacakra image is used in ABh ad Nś 22.1 (vol. 3, p. 147) to express one of the possible analyses of the compound sāmānyābhinaya: sāmānyasya samānīkrtasakalāngopāningakarmaṇā sato 'bhinayanam yenālātacakrapratimatā prayogasya jāyate. 'Sāmānyābhinaya is the action of enacting the sāmānya, i.e. the existent, by means of the action of all the major and minor limbs brought into harmony, by which the performance is produced in the likeness of a fire-wheel'. The same image is taken up again in ABh ad Nś 22.73-74, vol. 3, p. 180: evaṃ viśișțạ sāmānyenābhin̄̄yamānaḥ saṃbhūyābhinayairyuktaḥ sarvābhinayeșu sāmānyabhūta ity evam yaḥ sāmānyābhinaya asyā ekībhāvanibandhanabhūtāyā alātacakrasamnnibhatvasampāadikāyā sāmānyābhinayakriyāāạh prādhānyapradarśanārtham $\bar{a} h a[\ldots]$ 'In this way, sāmānyābhinaya is that which is common to all the enactments, i.e. the particular thing enacted in a general way, i.e. connected with the means of enactment taken together. In order to show the primary character of the activity of this sāmanny $\bar{a}-$ bhinaya, which, being the cause of unification [of the registers of acting] produces the resemblance [of the performance] to a fire-wheel, [Bharata utters the next verse].'

151 I am interpreting nätya as abhinaya on the force of a parallel in ABh ad Nś 28.3, vol. 4, p. 2, where Abhinavagupta explains the elements of performance while introducing the three ensembles: tatra caturvidhātodyam uparañjakam, uparañjanīyaś [corr., uparaścā$n \bar{y} \bar{a} \mathrm{E}_{1(4)}$ ] cābhinaya iti tayor ekasamnniveśātmakah samūhah kartaryah. 'Among the [elements of the performance], the fourfold instrumental music is the enhancing element, while enactment is what has to be enhanced. These two have to be made into an aggregate composed as a unit.' 
there is no disagreement about it. Furthermore, the group responsible for the melody, mutually combining [the action of the singer with that of the other melodic instruments], has to be constituted, as it were, into a fire-wheel. The regulation of the orchestra, which has in its turn different bases including the viña, the flute, and the singer, has to be similarly unified. Thus, these three [groups] subsequently have to be made into a lump. That is why what has been said [in Nś 28.7] is appropriate. ${ }^{152}$

The image of the alatacakra is clearly used in all these passages as a metaphor for theatre, in which processes of combination and unification occur on multiple levels and involve the activity and effort of multiple agents. Theatre is indeed a complex case of multimedial and intermedial performance that combines different arts such as dance and vocal and instrumental music. The preoccupation with the unity of theatre is referred to time and again in the Abhinavabhäratī, and its problematic cognition is addressed already in the first chapter:

If the [various] ancillaries [of theatre] are performed simultaneously, how is it possible to have a cognition of theatre as one, as it is impossible to be simultaneously aware of objects perceived by different sensory faculties? In addition, since the performance entails succession, it is even more problematic [to cognize theatre as one]. Therefore, how is the performance possible?153

$152 \mathrm{ABh}$ ad Nś 28.7, vol. 4, p. 4: nanu sāmānyābhinaye 'dhyāye etad uktam, satyam, tat tv abhinayavișayam, idam tu gītavādyanātyānāṃ parasparasya vișayam. nanu kasmāt trayo rāśayaḥ krtāḥ ityāśan்kamānenaivāpasārayati evaṃ gānaṃ ceti nātyaṃ tāvad uparañjanīyam. sāmānyābhinaye 'bhinayabalād ekatvam nìta eko rāśir iti nātra vivādah. svaragatarāśiś cānyonyasammilito 'lātacakravat kāryaḥ. vividhāśrayo 'pi vīnāvamnśagātrādigato 'pi vādyavidhir ekībhāvaṃ neya iti trayāṇām apy atha grāsīkaraṇam iti yuktam uktam.

153 ABh ad Nś 1.5, vol. 1, p. 7: yadiyugapad añgāni prayujyante tad bhinnākșagrāhyeșu yugapatsaṃvedanābhāvāt katham ekaṃ nātyam iti pratipattiḥ? kramaprayoge 'pi nitarām. tasmāt katham prayoga iti (translation based on Cuneo 2008-20091: 135). See also the following remarks about theatre being a visible and audible object extended over time in $\mathrm{ABh}$ ad Nś 1.11cd, vol. 1, p. 11: cakāreṇedam āha-tādriśā kenacid upāyena saṃbandhas tat kurute yena bhinnendriyagrāhya api drśsyaśravye ekānusandhānavișayatvạ̣ na vijahīta iti sāmānyābhinayakālaprānatvam prayogasya sūcitam. 'With the word "and" [in "visible and audible"], the author means this: the correlation with such a means, whatever it may be, makes it so that the visible and the audible, even though perceived by different sensory faculties, do not relinquish the nature of the object as a single interconnected unity. Thus it is suggested that the harmonious acting and the temporal [succession] are the vital breath of the performance.' 
Considerations of a similar order certainly match well with a spectatororiented aesthetics like the one developed by Abhinavagupta, although, as I suggest above, an attempt at finding unity amid multiplicity can already be spotted in Bharata's use of the alätacakra motive in chapter 28. As BansatBoudon (1992: 62) remarks, the metaphor of the fire-wheel also has the function of emphasizing theatre's power of illusion. The circle produced by the swift motion of a firebrand in fact becomes a stock example in the philosophical sources in talking about perceptual error, along with the 'city of the Gandharvas', the 'two moons', the 'moving trees', and the 'silver in the motherof-pearl.'. ${ }^{154}$ The question remains, however, how illusion is evaluated in Indian theatre, and how dance contributes to its construction.

In the context of Indian philosophy, says Fitzgerald (2012: 776), 'the theme of the alätacakra is familiar primarily as a Madhyamaka argument made to undermine naïve confidence in the accuracy of sensory experience and essentialistic conceptualization, and as such it is invoked by Nāgarjuna and his intellectual progeny alongside other things that may appear to the human senses but are not real: foam, bubbles, magic tricks, and Gandharva cities floating in the air'. While Nāgarjuna uses the alätacakra metaphor to point out the unreality of the samskāras, similar to dreams or mirages, the later Madhyamaka commentator Candrakirti has a more articulated description of the formation of a circle of fire:

Just as an inflamed firebrand quickly revolving is apprehended with the shape of a circle, since it depends on a mistaken vision of that [firebrand], $[\ldots] \cdot{ }^{155}$

The Āgamaśāstra of Gauḍapāda (c. 550-700AD?) probably contains the most developed image of the aläta, elaborated in six consecutive verses [Āś 4.47-52]. In this passage, the various trajectories created by the moving firebrand stand as a metaphor for the illusory movement of consciousness (vijñānaspanda) appearing as fragmented into an act of perception (grahana) and a perceiver

154 These examples are analysed differently in the different darśanas. The most complete study on error in the various philosophical schools is Schmithausen 1965. See also Rao 1998 on perceptual error. As for Abhinavagupta's conception of error, see Rastogi 1986. For error in the Pratyabhijñā system, see Torella 2002: 171, where the more common example of silver in the mother-of-pearl is dealt with by Utpaladeva in ĪPK 2.3.13 and Vrtti thereon.

155 Catuhśatakavrtti 197: yathā sajvalanasya indhanasya āśu bhrāmyamānasya tadgatadarśanaviparyāsanibandhanatvāc cakrākäropalabdhir bhavati [...]. This reference from the early seventh century is noted in Schmithausen 1965: 149 . 
(grāhaka). ${ }^{156}$ Without entering into Gauḍapāda's philosophical tenets, nevermind the possible origin of this example in a Madhyamaka milieu, as some have suggested, it is quite evident that the aläta and the various shapes created by its movement stand here for the illusory character of phenomenal reality as it appears in the perceptive act. As the title of the chapter of the Āgamaśästra containing these verses suggests-i.e. alātaśānti ('The Repose of the Firebrand') —one is expected to overcome the outer appearance of the shapes traced by the firebrand in order to arrive at the absolute reality.

In the Nyāyasūtra, the alätacakra motive is used to explain the non-simultaneity of the cognition of different actions, which may appear as simultaneous due to the rapidity of their succession, just as in seeing the circle traced by a firebrand in motion. In the Bhāssya, Vātsyāyana explains that it is impossible for either the same sensory faculty to produce several cognitions simultaneously, since one instrument can only accomplish one thing at a time, or for different sensory faculties to grasp several objects simultaneously. If it is argued that the cognition of several actions can happen simultaneously, the answer is that the simultaneity is only apparent: just as with the fire-circle, where the sequencing is not perceived because the swiftness of the rotatory movement allows the idea of the circle to be perceived as uninterrupted, the sequencing of neither cognitions nor actions, though real, is grasped because of their occurrence in rapid succession, and therefore one has the erroneous impression that actions happen simultaneously. ${ }^{157}$ Similarly, for the grammarian Bhartrhari, the alätacakra is a metaphor that explains the nature of actions that, although actually happening in a sequence, are perceived as if unitary and simultaneous. Just as the

156 Cf. Āgamaśāstra 4.47: rjuvakrādikābhāsam alātaspanditam yathā | grahanagrāhakābhāsam vijñānaspanditam tathā || 47 || 'De même que le mouvement d'un Brandon ardent (alāta) a une apparence droite, courbe, etc., de même le mouvement de la Conscience (vijñāna) a l' apparence de la saisie et du sujet saisissant' (translation Bouy 2000: 254).

157 See Ns 3.2.56-58, pp. 107-108: jñānāyaugapadyād ekam manah || na yugapad anekakriyopalabdheh || alātacakradarśanavat tadupalabdhir āśusañcārāt || NSBh 3.2.58, p. 208: āsusañcārād yathā alātasya bhramato vidyamānah kramo na gṛhyate, kramasyāgrahaṇād avicchedabuddhyā cakravad buddhir bhavati, tathā buddhīnām kriyānām cāśuvrttitvād vidyamāna h kramo na gṛhyate. kramasyāgrahaṇādyugapat kriyā bhavatīty abhimāno bhavatiti. 'In the case of the whirling fire-brand, even though there is sequence among the several perceptions of fire, yet it is not perceived, by reason of the extreme rapidity of motion; and the sequence not being perceived, there arises the idea of the continuity (of fire in revolution), which gives rise to the notion that there is a single circle of fire;--similarly in the case of cognitions also, sequence, even though present, fails to be perceived by reason of the rapidity of the cognitions or actions, and the sequence failing to be perceived, there arises the notion that the actions (or cognitions) appear simultaneously' (translation Jha 1939: 391). 
fire-wheel, in fact, corresponds to the points in time and space touched by the revolving firebrand, brought together in the mind, actions are made up of innumerable micro-actions happening in succession and grasped in succession, but conceived by the intellect as a single and unitary idea. ${ }^{158}$ Both Bhartrihari and Vātsyāyana stress the fact that the senses cannot simultaneously perceive different objects, or complex objects such as actions or words, although at times they may appear to do so.

Whereas in many philosophical systems the illusory character of the perception of the alätacakra has been regarded in negative terms, as a reality to overcome, in the grammarian's version, this trope works more as an operational device for describing the apprehension of actions. Similarly, despite being ultimately illusory in nature, the fashioning of the various elements of theatre into a unitary and continuous image - the fire-wheel—is the very condition for grasping the object called 'theatre' as a single and continuous whole. If, in Gaudapāda's metaphor, one is expected to overcome appearances to arrive at reality, in theatre it is quite the opposite: the illusion of the continuous circle has to be accepted for the entire duration of the theatrical performance.

Abhinavagupta explains in clear terms how the recognition and acceptance of the theatrical illusion are necessary conditions for a successful aesthetic experience, while he speaks about a group of obstacles threatening the experience of rasa for the spectators and how to remove them. ${ }^{159}$ The fourth and fifth obstacles, says the commentary on the rasasütra, are 'deficiency in the means of cognition' (pratītyupāyavaikalya) and 'lack of vividness' (sphutatuā$b h \bar{a} v a$ ), which are removed together. Sticking to the primacy of direct perception over the other means of valid knowledge, Abhinavagupta maintains that even when we perceive something illusory, such as a fire-wheel, our perception can be invalidated only through a more forceful direct perception that is subsequent to it. The means to achieving such a clear apperception are indeed the four registers of acting, the abhinayas, combined with all those elements that

$15^{8}$ See VP 3.8.7-8: yathā gaur iti saṃghātaḥ sarvo nendriyagocarạ̣ | bhāgaśas tūpalabdhasya buddhau rūpam nirūpyate || indriyair anyathāprāptau bhedāmśopanipātibhị | alātacakravad rūpam kriyañām parikalpyate \|| 'Just as the entire group [of phonemes forming] the word "cow" cannot [simultaneously] be the object of the senses, its form however is determined in the intellect after it has been apprehended part by part. Likewise, the form of actions is imagined [as one in the intellect], just like a fire-wheel, even if it is grasped differently by the sensory faculties rushing towards the parts of differentiation.' The example given by Bharthari in kārikā 9 for the non-unitary and processual nature of action is cooking, which includes parts such as the pouring of water and so on, which in turn have their own parts.

159 On the obstacles, see above, n. 128. 
provide a somewhat realistic touch to the performance, namely the worldly convention (lokadharmī), ${ }^{160}$ manners (vrtti), ${ }^{161}$ and local usages (pravrtti):162

Moreover, in the absence of the means of cognition, how is the cognition possible? Even though a word or an inferential sign causing a non-vivid cognition might be present, the cognition does not come to rest [in them], because the expectancy persists for a proper understanding, i.e. a direct perception consisting of a vivid cognition. As [Vātsyāyana] said [in the Bhāsya ad Nyāyasūtra 1.1.3]: 'All valid knowledge resolves into direct perception'. This is so because even in the case of [an illusion such as] a fire-wheel etc., that knowledge can be dismissed only by means of another forceful direct perception, since there is an intimate awareness that what we have directly perceived ourselves cannot be proved to be otherwise even by hundreds of verbal testimonies and inferences. This is indeed the ordinary sequence. Therefore, the consecrated way to remove both obstacles are the registers of acting, assisted by the worldly convention, the manners, and the local usages. For dramatic representation (abhinayana), differently from operations requiring words or inferential signs, is akin to the operation of perception. We will establish this later on. ${ }^{163}$

16o Two conventions (dharmī) are listed in the nătyasamgraha as topics of theatre, namely the lokadharmī or 'worldly convention', and the nātyadharmī or 'theatrical convention'. The two are described by Bharata in Nś $13.70-82$ as conventions, or manners of performance (dharmī or dharma, glossed by Abhinavagupta as itikartaryatā), used for representing things on stage. Lokadharmi is the way of enacting in a realistic fashion, following the way things are in the world, while nătyadharmi typically involves a greater degree of stylization and dramatization, and follows the ways that are proper to theatre. For the definition of lokadharmī, see Translation n. 79, and n. 82 for nātyadharmī. On lokadharmī and nātyadharmī, see Bansat-Boudon 1992: 155-169 and Raghavan 1993: 201-241.

161 On the four manners, see $\S 1 \cdot 3 \cdot 3$, n. 64.

162 The four pravrttis are described in Nś ch. 13 as local usages or customs, which correspond to the four regions of India in the four cardinal directions. See Bansat-Boudon 1992: 17818 o.

163 ABh ad rasasūtra, vol. 1, p. 275: kiṃ ca pratītyupāyānām abhāve katham pratītih? asphuțapratītikāriśabdalingasaṃbhave 'pi na pratītir viśrāmyati, sphuțapratīitirūpapratyakṣocitapratyayasākānkșatvāt. yathāhuḥ 'sarvā ceyam pramitịh pratyakșaparā' iti, svasākșātkrta āgamānumānaśatair apy ananyathābhāvasya svasamvvedanāt, alātacakrādau sākșātkārāntareṇaiva balavatā tatpramityapasāraṇād [corr. Pollock (2016: p. 387, n. 115) following $\mathrm{KA}$, taptam ity apasāraṇād $\mathrm{E}_{1(4)}$ ] iti laukikas tāvad ayam kramaḥ. tasmāt tadubhayavighnavighāte 'bhinayā lokadharmìvrttipravrttyupaskrțāh samabhișicyante. abhinayanam hi saśabdalingavyāpāravisadrśam eva pratyakșaryāpārakalpam iti niśceșāmaḥ. In this same passage, Gnoli (1968: 68-70) translates the expression 'iti laukikas tāvad ayam kramaḥ' as 'this is quite an ordinary process'. Pollock (2016:197) does not translate this. I tend to agree, 
Although it might be quite evident that the representation should aim at creating a unitary and coherent image, one must not forget that this image has been given the status of an alätacakra. The spectator is indeed well aware that what he is witnessing is not real, but he accepts the 'reality' of the fiction. To be precise, it is the very judgement of his cognition of theatre according to the criterion of truthfulness and falsity that is suspended. More than an illusion, I would argue, the alätacakra of theatre has the status of a fiction, which has to be accepted wholeheartedly by the spectator lest the aesthetic process be on the whole invalidated. This 'willing suspension of disbelief' is guaranteed for the spectator by the special cognition of theatre in general as neither real nor unreal, a cognition whose status is incessantly repeated to be that of a quasi-evident direct perception (pratyakșasākșātkārakalpa), and that of the performer in particular, whose identity is perceived as ambiguously oscillating between the actor and the character.

The personal identity of the performer-his being Caitra or Maitra, living in a particular time and space, in the classical example-is concealed by the costume and his skilful use of the registers of acting, combined with the superimposition of the name of a famous character like Rāma. ${ }^{164}$ However, the performer is not perceived as the character superimposed on him as in illusionistic play, since his identity as 'actor' was disclosed to the spectator on the occasion of the preliminary rite, the pürvaranga; the latent impression 'this is an actor' is still lingering in the spectator, and his cognition does not come to rest completely on the character evoked by the poetic text. In the preliminary rite, in

with Cuneo (2008-20091: 293), that a more apt translation would be: 'This is indeed the ordinary sequence'. I believe in fact that what Abhinavagupta wants to stress here is that the sequence by which the perception of a fire-wheel comes to be invalidated by another, subsequent perception - for instance, that of the firebrand coming to a halt-is proper to the ordinary experience. In theatre, on the contrary, different dynamics between cognitions are at play.

164 This is explained in the first chapter as follows, with regard to the particular cognition of theatre as a determination or 'recognitive cognition' (anuryavasāya). ABh ad Nś 1.107, vol. 1, p. 37: āhāryaviśeșādinā nivrtte taddeśakālacaitramaitrādinațaviśeșapratyakșābhimāne, viśeșaleśopakramena ca vinā pratyakșāpravrtter āyāte, rāmādiśabdasyātropayogāt prasiddhatadarthatayādaran̄īyacaritavācakasyāsaṃbhāvanāmātranirākaraṇenānuvyavasāyasya pratyakșakalpatā [conj. Gnoli, ${ }^{\circ}$ kalpanā ${ }^{\circ} \Sigma_{\mathrm{M}} \mathrm{E}_{1(1)}$, ${ }^{\circ}$ kalpanātye $\mathrm{E}_{1(2)} \mathrm{E}_{1(4)}$ ]. 'When the presumption of perceiving a specific actor such as Caitra, Maitra, etc. in their specific time and place is removed by a particular costume and [other accoutrements], and [at the same time] is achieved because there can be no direct perception without the introduction of a minimum part of particularity, the determination [of the spectator] gets the status of a "quasi-perceptual cognition" by averting the mere non-verisimilitude, because the words expressing such worthy deeds have well-known referents thanks to the use of the names of Rāma and so forth in this [narration].' 
fact, all the spectacular elements are on display and the performer enters as the sütradhära, accompanied by two assistants, who are perceived as actors since they are not properly dramatis personae, although they do play a part, as they enact the prologue (prastāvana) composed by the dramatist. ${ }^{165}$ The whole is moreover immersed in the alluring complex of the charming elements, which allows the spectator to emotionally adhere to the fiction. ${ }^{166}$

The construction of the fictionality of the character, as I have just sketched here, is explained by Abhinavagupta as tightly connected to the process of generalization (sādhäranikarana $){ }^{167}$ the absence of which coincides with the second obstacle to the aesthetic experience, the 'immersion in temporal and spatial determinations perceived as limited to one's own self or to somebody else' (svagatatvaparagatatvaniyamena deśakālaviśeșāveśaḥ):

165 In the prologue ( prastāvanā) of the play, the stage manager or sūtradhära usually engages in a metatheatrical dialogue with an assistant, the jester, or an actress about the play that is just about to start, providing information about the name of the play and the playwright, their qualities, etc. The sūtradhāra, besides announcing the play in the guise of an actor, does also enact a character in the story. The importance of the prologue for the construction of the ambiguous cognition of theatre is stressed in the same passage, ABh ad NŚ 1.107 (ibid.): abhinayacatuștayena svarūpapracchādanam prastāvanādinā națajñānajasamskārasāciryam. 'As to the concealment of the identity [of the actor] through the fourfold enactment, it is assisted by the latent impressions born out of the knowledge "it is an actor" due to the prologue[, the preliminary rite, etc.].'

166 ABh ad NŚ 1.107 (ibid.): hrrdyagītādyanusyūtatayā camatkārasthānatvād dhridayānupraveśayogyatvam. '[The cognition of theatre] has the capacity of entering the heart, as it is the abode of rapture on account of its being intertwined with elements such as pleasant music and so forth.'

167 Famously, sādhāraṇikaraṇa is the 'generalization' (or 'commonalization', as Pollock translates Bhațta Nāyaka's concept) of the emotional situation embedded in a work of art. Through generalization, the emotions are freed from their spatial and temporal connotations, as well as from the reference to a particular individual. In my understanding of sādhäranikarana in theatre, and how it is boosted by the charming elements, I follow Reich 2018, who speaks of a twofold process concerning both the object of the poetic description (the vibhāvas and other aesthetic factors) and the awareness of the spectators. Sädhäraṇikaraṇa, which Reich equates with the transformative power that Bhaț̣a Nāyaka calls bhävakatva, 'also applies to the spectators, changing the nature of their awareness. When it strips the objects of their particularity it also strips the spectators of the ordinary, habitual reactions they would have to such objects' (ibid.: 537-538). Reich's analysis of sādhāraṇīkaraṇa/bhāvakatva/bhāvanā in Bhațta Nāyaka stresses its Vedantic background as the creation of a special state of awareness that in literature is prompted by rhetorical figures and other literary devices (ibid.: 549). In Abhinavagupta's analysis of the aesthetic experience triggered by drama, however, the accent is not on literary language, but on stage presentation, and the role of the literary devices is transferred to the charming, extraordinary elements (cf. also the elimination of the third obstacle in $\mathrm{n} .129$ above). 
As far as its elimination is concerned, the expedient consists in the manner in which the individuality of the actor is concealed through the headgear and the [other accoutrements], after it has been apprehended through the disclosure of the preliminary rite $^{168}$ as [seen] in the verse 'one should not insist too much on [dance and song ...]'169 and through the viewing of the prologue. This is assisted by the theatrical convention (nātyadharmī), which encompasses extraordinary (alaukika) [elements such as the] distribution of conventional languages, the lāsyāngas, the subdivisions of the stage and of the playhouse, and so forth. ${ }^{170}$ When this [obstacle is removed], in fact, there is no such [cognition] as: it is the pleasure or pain of this specific [actor or character], in this specific place, at this specific time', because the nature of the [performer] is concealed,

168 Here Pollock seems not to take into account the negative particle in a-niguhanena, as he translates 'and the occultation effected by the theatrical preliminaries'. On the contrary, in the preliminaries, just as in the prologue, the idea that 'this is an actor' is disclosed. See following note.

169 NŚ 5.158-159: kāryo nātiprasañgo 'tra nrttagìtavidhim prati | gīte vādye ca nṛtte ca pravrtte 'tiprasañgatah || khedo bhavet prayokț̣nāạm prekșakāṇām tathaiva ca| khinnānāṃ rasabhāveșu spaștatā nopajāyate || 'In the [pūrvaranga], there should not be too much elaboration towards dance and songs. When vocal music, instrumental music and dance are protracted for too long, the performers will be tired and the spectators bored. If the [performers] are tired and [spectators] bored, a clear [cognition] of rasas and bhāvas cannot be obtained.' The disclosure of the idea of the actor occurring in the pürvaranga is explained by Abhinavagupta in connection with the second verse, in ABh ad Nś 5.159, vol. 1, p. 244: prekșakāṇām ity anena sāmajikānām pūrvarañge sphuțaiva națabuddhir bhavatīti darśayati. tatsaṃskārasaṃskrtatvāt tattvadhịh $\left[\mathrm{E}_{1(1)}{ }^{\mathrm{pc}}\right.$, tantudhịh $\mathrm{E}_{1(1)}{ }^{\mathrm{ac}}, t u \mathrm{E}_{1(4)}$ ] bhrāntyādibuddhiś ca nātyadhīr bhavatīti sūcayati. yadi hi teșu nātyabuddhir evotpādan⿳亠㐅⿵a à syāt pratyuta prayatnena națabuddhisampādakam pūrvarañgaprastāvanādi tān prati gopanīyam syāt. darśitam caitad asmābhị prathamādhyāye. "By the word "spectators", [Bharata] indicates that for the audience, the idea of the actor [and not that of the character] becomes clearly evident in the pürvaranga. Later on, on account of having prepared their minds through the impregnations of the [cognition of the actor], the idea of reality (tattva) and the idea of illusion (bhrānti) etc. become the idea of theatre (nätyadhì). For if only the idea of theatre had to be produced for the [spectators], then the prastāvanā, the purvaranga, and the other parts that produce the idea of the actor should have been concealed from the [spectators]. This has been already explained in the first chapter.' The reference is to ABh ad Nś 1.107, quoted above in n. 165 .

170 The extraordinary elements of the nātyadharmī referred to here belong to the performance of the play, so the lāsyāngas must be the 'dramatic fragments' or 'amorous vignettes' described in Nś chapter 19, and not those of the pürvarañga. My understanding is based on the distinction established in a penetrating analysis by Bansat-Boudon (see above, n. 113), against Gnoli's (1968: 65) translation of lāsyānga as 'women's dance' and Pollock's (2016: 197) as 'preliminary dance'. 
and because [the cognition] does not come to rest on the nature proper to the other superimposed individuality, [i.e. the character,] either, as there can be no rest in a [fictional] appearance [that is recognized to be so]. The [cognition], in fact, culminates only in the concealment of the nature belonging to that real [spectator]. ${ }^{171}$ To clarify: [types of dramatic lāsy $\bar{a}-$ nggas such as] the äsinapäthya, the pușpagandhika, and the like are not seen in the ordinary world. Anyway, it cannot be said that they do not exist at all, because they could exist somehow. ${ }^{172}$ The sage has resorted to all this as a preparation, insofar as it facilitates the gustation of rasa through the accomplishment of the state of generality (sädhäranībhāva). ${ }^{173}$

This passage shows quite well how opposite trends are at play in the construction of dramatic fiction, a process ultimately aimed at triggering the relish of rasa for the spectator, the real protagonist of the aesthetic experience: the

171 I understand tadīya- in satyatadīyarūpanihnavamätra as referring to the spectator himself, along with Cuneo (2008-20091: 292). Gnoli (1968:66) takes it as referring to both 'the real being of the actor and the real being of the character he is playing', Pollock as the 'real form of the actor'. I think that the concealment here concerns the individuality of the spectator, which corresponds to the action of the charming elements, explained just afterwards, in effecting the process of generalization of emotion for the spectator, so that the spatio-temporal limitations connected with himself are suppressed. The reference to the spatio-temporal limitations concerning another (the actor or the character) are, on the contrary, explained as being removed by the enactment, and by the preliminary rite and the prologue.

172 Gnoli contrasts this sort of existence with that of nonentities, since the former is 'a datum of one's own consciousness' (Gnoli 1968: 66, n. 4). According to Gnoli, such a kind of existence applies, in Abhinavagupta's statement, to the represented character; however, I think it refers to the extraordinary elements of the nätyadharmī, to which the lāsyängas belong. These elements are often defined as otherworldly (alaukika), yet possible (sambhavin). As Bansat-Boudon (1992: 155) puts it in her treatment of nātyadharmi, 'l'alaukikatva du théâtre n' est en aucune façon invraisemblable ou impossible: pour le retrouver dans la réalité, il n' est que de savoir regarder, et c 'est à quoi, précisément, le théâtre forme son public'. See also ibid.: 337, n. 270.

173 ABh ad rasasūtra, vol. 1, pp. 275-276: tadapasāraṇe 'käryo nātiprasañgo 'tra' ityādinā pūrvarañgānigūhanena prastāvanāvalokanena ca yo națarüpatādhigamas tatpurassaraḥ pratiśîrșakādinā tatpracchādanaprakāro 'bhyupāyaḥ alaukikabhāṣādibhedalāsyāngaraṅgapițhamaṇdapagatakakșyādiparigrahanātyadharmisahitạ. tasmin hi sati 'asyaivātraivaitarhyaiva ca sukham duhkham vă' iti na bhavati pratītih, svarūpasya nihnavāt, rūpāntarasya cāropitasya pratibhāsaviśrāntivaikalyena svarūpe viśrāntyabhāvāt. satyatadīyarūpanihnavamātra eva paryavasānāt. tathā hi-āsīnapāthyapușpagandhikādi loke na drșțam. na ca tan na kimcit. kathaṃcit saṃbhāryatvāt iti eșa sarvo muninā sādhāraṇibhāvasiddhyā rasacarvaṇopayogitvena parikarabandhạ samāśrita. Pollock (2016: 197) does not seem to translate the last example with the lāsyāngas. 
first operates through a distancing from the events represented, reminding the spectator that what he is witnessing is, after all, a fiction, while the other hides the fiction and entangles him in those very events, accounting for his sympathetic response to them. This twofold tension alone can provoke the special cognition of theatre as neither real nor unreal, necessary for an aesthetic experience detached from the limitations of ordinary experience. ${ }^{174}$ From the point of view of the performance, three stages can be tentatively identified in provoking this 'detached-cum-involved' cognition: initially, the spectator is allowed to see all the elements of theatricality that are used to construct the fiction, the firebrand and the hand holding it, so to say; then, the dramatic representation starts and the various scenes are displayed, i.e. the firebrand begins to revolve and the image of the fire-wheel is formed; finally, through the action of the charming elements, the spectator turns towards the illusory image and sympathetically adheres to the events represented. Obviously enough, this schematic picture is bound to involve a certain degree of imprecision and simplification. The charming elements, such as singing, music, and dance, for instance, are present throughout the play, for instance in the lāsyāngas; however, they are operative from the preliminary rite, where they prepare the spectator to attend to an extraordinary event by getting rid of their own personal everyday preoccupations. Besides being enchanted by the extraordinariness of the group of charming elements, to the extent that he does not even start wondering about the reality of the representation and becomes disentangled from his own state of mind, the spectator is at the same time reminded that what he is witnessing is nothing but a wondrous alätacakra. It does not matter, for the sake of the effect, that the image provided by the revolving firebrand is illusory; as long as the circle is perceived as unitary and the stick is unseen, the image has validity in the mind of the spectator who grasps it.

It seems to me that in all the occurrences examined so far, the alätacakra motive raises a concern about the construction of a unitary and ordered cognition of theatre from disparate and heterogeneous elements, rather than pointing to the fact that, if theatre is created in the image of a fire-wheel, it remains an object impossible to grasp. Even though a certain distance from the events

174 See also Cuneo (2013: 64-65) who talks about a 'sort of clash between cognitive stances'. Using the modern perspective of theatrical 'embodiment', Fischer-Lichte (2008: 148) talks about the phenomenon of 'perceptual multistability', in which the spectator's perception is made purposefully to oscillate between the 'phenomenal body' (read: the actor) and the 'semiotic body' (read: the character). 'Aesthetic perception', she says, 'takes the form of oscillation. It switches focus between the actor's phenomenal and semiotic body, thus transferring the perceiving subject into a state of betwixt and between' (ibid.: 88-89). 
represented is indeed required of the spectator, this does not strike me as the specific function assigned to dance with regard to the alätacakra metaphor of theatre. ${ }^{175}$

One last occurrence of the fire-wheel image in the ninth chapter of the Abhinavabhäratī, which treats the hand gestures, might provide further evidence for the interpretation of dance as a cohesive factor in the performance. ${ }^{176}$ After describing the hand gestures that are commonly used for enacting different meanings (abhinaya-hasta), Bharata lists a separate group of hand gestures that he qualifies as gestures for dance (nrtta-hasta). Since these hand gestures do not represent anything, their treatment in one of the chapters devoted to bodily acting is quite at odds with the rest of the exposition. One would have expected to find this group of gestures in the fourth chapter, entirely devoted to dance and its units of movement in their abstract, non-semiotic dimension. The commentator provides the following explanation for this unusual arrangement in Bharata's treatise:

By saying 'nrttahastān etc.' [Bharata] qualifies this [group of gestures] with the word 'dance' in order to show that the hand gestures for enacting (abhinayahasta) are similar to a fire-wheel because they are part of a single course [of action] (ekavartanānupraveśa) ${ }^{177}$ since the gaps [occurring between them] are hidden [thanks to dance]. [...] [Moreover, the qualification 'dance' is used] in order to proclaim the fact that the [various cognitions issued from the enactments] come to rest in a single sentence meaning (ekavākyārtha), since it is in [their] nature to [follow] a course [that is sometimes] mild, [sometimes] vehement. ${ }^{178}$

175 With this I would like to take distance from Bansat-Boudon's interpretation of the passage expounding the role of dance in theatre. As I mentioned in n. 144 above, Bansat-Boudon interprets dance as a sort of intermezzo that provides the spectator with some pause in the performance, by means of which he is able to plunge into the meaning and taste the rasa: 'Aussi convient-il [...] d'interrompre de temps à autre le lent tournoiement de ce cercle de feu que doit être la représentation afin que soit évité le vertige qu'il susciterait immanquablement et qui serait tout le contraire d'un enchantement. [...] La danse, explique l'Abhinavabhāratī, a pour vocation de ménager ces pauses nécessaires, [...]' (Bansat-Boudon 1992: 63).

176 Bansat-Boudon also recognizes this role for dance, though with regard to other passages: 'par la vertu de la grâce et de la tendresse qu' elle déploie inlassablement, la danse assure la cohésion de la représentation (notamment, lorsqu' il s' agit de passer d' un rasa à un autre, ou d' un registre de jeu à un autre)' (Bansat-Boudon 1992.: 402).

177 For an analogous use of the compound vartanānupraveśa, see ABh ad Nś 4.61cd-62ab in $\S 2.3$, n. 45, and the explanation thereof.

178 ABh ad Nś 9.11-17, vol. 2, p. 27: eteșām tv abhinayahastānām chidracchādanenaikavartanā- 
In my understanding of this passage, dance provides the necessary link between the various enactments, which are chained one after the other so as to encompass the whole performance. However, one should not necessarily imagine that each scene was linked to the following by means of a danced intermezzo. Even though it is possible that moments of dance were indeed added to the performance, either by embedding them in the plot as cases of ekphrasis or, at the discretion of theatre practitioners, as part of the gorgeous manner or as an element of the theatrical convention (in a läsyänga, for instance), I would refrain from overemphasizing the presence of dance in classical Sanskrit theatre. It seems to me that Abhinavagupta's analysis is subtler and is meant to operate within the smallest units of the enactment. If this is correct, the general definition given by Abhinavagupta to the basic units of dance, the nrttakaranas,

nupraveśā alātacakrapratimatāṃ darśayitum, masrṇoddhatavartanātmakatayā caikavākyārthaviśrāntatāṃ prathayitum, [...] nẹttaśabdena viśeșyạ̣ nirdiśati nṛttahastān ityādi$n \bar{a}$. The compound masrnoddhatavartanātmakatayā is not straightforward, but one could connect it with the twofold character of the text to which the acting and dance are applied, which in turn determines the character of the movement as mild or vehement, since masr$n a$ and $u d d$ dhat $a$ are the two terms consecrated to describing bodily movement when it combines with a poetic text, on which see $\S 2.3 .2$ and Translation 8.4.1-2. The other editions give a slightly different, more elaborate text, which I suspect has been supplied by Madhusudan Sastri and then followed by Dvivedi and Nagar: eteșām ț abhinayahastānām alātacakrapratimatām darśayitum, mārgāṇām mașrnoddhatachidravartanātmakatayā mașrnatādinivrttaye vālukotkșepaṇena uddhatotsāraṇena chidracchādanena caikavartanānupraveśavad ekābhineyārthe viśrāntatām prathayitum, [...] ( $\mathrm{E}_{2}$, vol. 2, pp. 871-872; $\mathrm{E}_{3}$, vol. 2 , p. 387 ; $\mathrm{E}_{4}$, vol. 2 , p. 20 ). It could be translated as follows: 'In order to show that these hand gestures for enacting are similar to a fire-wheel, and in order to proclaim the fact that the [various cognitions issuing from the enactments] come to rest in a single sentence meaning, just as when one enters a single path and, since it is in the nature of roads to have muddy patches and bumps and holes, throws sand [over the mud], removes the bumps, and fills the holes in order to remove such [obstacles] as softness etc. [...].' In both cases, dance is seen to supply the unity or homogeneity required for the spectator's cognition to rest on its object, be it a single scene or the whole play. The same idea is repeated and developed in Kallinātha's Kalänidhi, which quotes the same passage of the Abhinavabhāratī. Kalānidhi ad SR 7.90, vol. 4, p. 27: kim cābhinayaprastāve nrttam apy upakarotīti. āveșțitādibhih abhinayasya [conj., abhinayasya $\overline{ }^{\circ} \mathrm{Ed}$.] vicchinnākāratām apohya vākyārthaviśrāntipratītijananāt. yathāha abhinavaguptācāryo bhäratīyavivrtau. 'Moreover, it is said that when the enactment is produced, dance also assists since, by means of the āveștita and other [rotatory movements of the hands, the four karanas belonging to dance,] it prevents the acting from appearing as interrupted and thus engenders a cognition that comes to rest in sentence meaning, as Abhinavagupta stated in his commentary on Bharata's text.' The āveștita is part of a group of four karanas executed by the hands through a rotating motion of the fingers and wrists. They are defined in Nś 9.213-219, and are often mentioned by Abhinavagupta to exemplify the connecting movements in some of the karana sequences. 
could be extended to include any beautiful movement leading from an initial position in space to a final one, ${ }^{179}$ hence even to movements occurring between one enactment and the other, or between one expressive gesture and the one immediately following it, if we consider that by enactment, even the single representation of an object through a gesture can be intended, and that there were cases in which the text was enacted word by word. ${ }^{180}$

Such interpretation relies on an extended meaning of 'dance' as including any abstract movement performed in an uninterrupted manner, which at the same time accounts for its irruption into the realms of dramatic enactment, where it aims at providing continuity by hiding the unavoidable gaps. To adduce an additional piece of evidence, I would like to recall another key passage in the fourth chapter, where Abhinavagupta comments on the uses of karanas in a play, enumerated in Nś $4.55^{\mathrm{cd}}-56 \mathrm{ab}$, in the following way:

That which will be called 'dance' ( $n r t t a)$ as an element of dramatic acting (abhinaye) is employed [in theatre] because it hides the gaps (chidrapracchädana) occurring in between the various enactments (abhinayāntarāla.$^{181}$

No doubt, the implicit reference is the oft-quoted verse in Nś 8.14, of diffcult interpretation, in which Bharata lists dance, along with the śākhā and the ankura, as elements of [bodily] acting. ${ }^{182}$ In this light, it becomes evident that Abhinavagupta is attempting to establish the autonomy of dance outside of its canonical performance as part of the karanas and angahäras in the preliminary rite, and to account for its autonomous function within the theatrical performance, keeping it apart from bodily acting yet deeply intertwined with it. Once more, the modern concept of semiotic and phenomenal body elaborated by Fischer-Lichte comes to our aid in understanding how the same body movement can be analysed as carrying out two distinct functions in performance, without necessarily postulating phases of abstract dance that alternate with phases of mimetic acting. The sentence, and the rasa it encapsulates, is

\footnotetext{
179 See $\$ 2.2$, n. 40 .

18 o See above, n. 58 .

181 ABh ad Nś 4.55cd-56ab, vol. 1, p. 94: abhinaye vastutvena yan nrttam vaksyate 'bhinayāntarālavarticchidrapracchādanād etat prayujyate. For the whole passage, see $\S 2.2, \mathrm{n} .61$.

182 For the text and translation of Nś 8.14, see above, n. 17, and for other quotations of this verse, see $\S 2.2$, n. 45, § 3.2, n. 53, § 3.4.1, n. 135, and Translation n. 71. On śäkhā and aŕkura as stages in the protocol of the corporal harmonious acting, see above n. 53, and below n. 186.
} 
indeed the meaningful unit that the body movement is called on to express. The semiotic body communicates the meanings by way of mimesis, while the phenomenal, non-semiotic body helps the spectator grasp the enacted meanings as a continuum, culminating in the sentence unit: on the one hand, it hides the gaps occurring in the intervals between the enactments, revealing the image of the fire-circle; on the other hand, it allows the mind of the spectator to rest on the sentence meaning.

Besides the image of theatre as an alätacakra, a homogeneous and wondrous whole, in which dance assures cohesion and dynamism, the relation of dance to theatre shall now be considered in the light of the second metaphor as well, that of the bracelet. Together with the fire-wheel, the bracelet and the garland work as similar metaphors for theatre as a Gesamtkunstwerk. Yet the metaphor of the bracelet works even better in highlighting how dance operates in close association with dramatic acting and the other components of theatre, to the point of raising a possible confusion about their respective identities and roles. As pointed out by Bansat-Boudon (1992: 62), as metaphors for performance, the garland and the bracelet highlight the multifariousness of the flowers or gems joined in the thread. While the theatrical performance, in our passage, is compared to the whole bracelet, and the enactments to its clear gems, dance is the thread that keeps them together and remains visible throughout. This, in my view, makes a stronger argument for the specific role of dance within theatre. ${ }^{183}$ While it strings together the various enactments, dance also provides the necessary link between theatre and music: dance is homogeneous with theatre, since both use the body as a main instrument, albeit in different ways, while with music it shares an alluring character and the connection with rhythmic patterns, while remaining non-homogeneous with it. ${ }^{184}$

Although drawing on a reconstructed net of cross references, sometimes fragmentary, this exploration of the role of dance in the construction of dramatic fiction has highlighted Abhinavagupta's attempt at finding a rationale in Bharata's own words, while skilfully furthering his own personal interpretation of the aesthetic experience as triggered by the multimedial object that is theatre. The loss of the commentary on the eighth chapter of the Nätyaśāstra, the first one dealing with bodily acting, represents a serious but unavoidable

183 In a similar vein, although in a different context, a passage at the beginning of the section on music assigns to rhythm, or to the rhythmic part of theatre (tālāmśa), the function of a thread that joins together or coordinates the performance and its various elements. Cf. ABh ad Nś 28.1, vol. 4, p. 1: tālāṃśo 'pi prayogam sūtrakalpatayā samīkurvan.

184 The terms used are samajātīya (passage under discussion, cf. Edition 6.9.5), and dvitīyajātìya (nrttasya gïtadvitīyajātīyatvāt, cf. Edition 2.4.6). 
limit to the present enquiry. However, it has been shown how an exploration of the chapter on dance and its network of textual references allows us to partly reconstruct the context of the discussion on the nature and function of dance, namely its problematic relation with dramatic acting. Besides the problematic use of dance within theatre, the use of theatre-or at least some of its characteristic features - within dance will be considered next.

\subsection{Reshaping the Idea of abhinaya in Dance}

The characteristic feature of abhinaya is that, unlike dancing or singing a melody, it always depends on a text, which it seeks to communicate in a particularly vivid way, engaging the mind of the spectator as if he or she is witnessing real-life events. Even when it appears disconnected from a text, it may simply be the case that the bodily acting is not being performed at the very same time as the vocal acting; however, both ultimately rely on the dramatic text and its linguistic matrix. An illustration of such diachronicity between words and gestures is offered in those phases of the acting protocol, defined in the chapter on harmonious acting (sāmānyābhinaya), in which gestures and facial expressions are used by actors to communicate meaning even without speaking. In these phases, the dependence of gestures on the dramatic text can be called into question, as Abhinavagupta suggests at the junction between the explanation of the corporal harmonious acting (śārìra-sāmānyābhinaya) and verbal harmonious acting (vācika-sāmānyāahinaya)::185

Even if a sentence (i.e. a text) may be [pronounced], the body [can move] even on its own, without any [verbal] object [to be enacted]. That is why some people considered the śákhā, the ankura, and the nātyayyita as [bodily acting] disjoined from verbal sentences. Thus they restrict [Bharata's statement] — when he says that [he will explain the verbal object] of all these [forms of corporal acting] — to the vākya, the sūca, and the nivrttyankura alone. [However,] they do not know the real state of things, since each and every enactment (abhinaya) depends on a sentence, otherwise impropriety would ensue. Apart from this, in fact, there is no other restriction [in the use of abhinaya]. It is possible to disjoin the sentence

185 Cf. Bansat-Boudon 1992:12 'That homogeneous acting is presented by Bharata as threefold: thus, there are an «emotional» (sāttvika), a «verbal» (vācika), and, lastly, a «corporal» (śārīra) sāmānyābhinaya.' 
[from its bodily enactment] only insofar as it may be simultaneous or non-simultaneous with it. ${ }^{186}$

The connection of the śa $\bar{k} h \bar{a}$ with a sentence is the most difficult to explain, since all definitions available are elliptical, and its explanation as an acting technique was probably to be found in the lacuna in chapter $8 .{ }^{187}$ What emerges from the sparse references to it is that the śăkha must have been a coordinated bodily movement on the verge of dance. ${ }^{188}$ The arkura is explicitly said, in Bharata's definition, to be performed without words, ${ }^{189}$ while the nivrttyankura looks more like the sūcā in that it displays the symptoms of the emotions affecting the character when hearing the words of another, but is also followed by a sentence pronounced by the same character. In this sense it is categorized, together with the vākya and the sūcā, with the phases of the bodily acting protocol more evidently connected with the verbal enactment. ${ }^{190}$ The phase called nātyāyita represents an especially interesting case in the discussion of the nature of dance in the fourth chapter. In the nattyayita of the second type, a dhrū $v \bar{a}$ song is delivered by the vocalist, to which the actor adds bodily acting through gestures and facial expressions. ${ }^{191}$ Indeed, this may look quite similar

186 ABh ad Nś 22.51, vol. 3, pp. 174-175: vākyabhāve yady apy ātmāpi śarīro nirvișaya eva tena yad eke śākhāṅkuranātyāyitānām ca vākyavirahitatvam manyamānā eteșām iti sarveșām ityādi vākyasūcānivrttyañkuramātravișayatvenaiva saṃkocayanti, te na tattvajñāḥ, sarvo 'py abhinayo vākyopajīivanam antareña niyamahetvabhāvād asamañjasatām abhyeti. kevalạ̣ tatkālikātatkālikādimātreṇa vākyam bhidyatāṃ nāma.

187 See $n .42$ above.

188 As Bansat-Boudon expresses it: 'Ainsi la śākhā, succédant à l'añkura qui déjà avait evincé la parole au profit du corps, mais dont la vocation était de déployer le sens, représente-telle le point ultime de la gestualité aux frontières de la danse avec laquelle elle entretient des relations privilégiées' (1992: 350). The common traits of dance and the śākhā would be the use of the vartanā, movements typical of the dance lexicon (cf. $§ 2.2, n .46)$, and their belonging to the kaisiki vrtti.

189 Cf. the expression nirvacana- in the definition of the ankura (Nś 21.46: hrdayastho nirvacanair añgäbhinayaḥ krto nipunasādhyah | sūcaivautpattikrto vijñeyas tv an்kurābhinayah |l), glossed by Abhinavagupta as vacanaśünya. For a translation of the whole passage, see Bansat-Boudon 1992: $375^{-375}$.

190 An example of nivrttyankkura in the Ratnāvalī, quoted by Abhinavagupta and translated in Bansat-Boudon 1992: 386, is quite telling in this regard. Bansat-Boudon (ibid.: 353) considers the nivrttyankura more akin to the aikura, because both make use of the $s a$ ttva, the facial expression, and body, to represent feelings rather than objects. This is undoubtedly the case; however, the discourse pronounced by the second character in the nivrttyainkura - the one who, unseen, hears the words uttered by the first one-seems to be definitional of this phase of the acting protocol.

191 On the two types of nātyāyita in the sāmānyābhinaya, see Bansat-Boudon 1992: 377-384, 1995, and n. 53 above. 
to a dance, since the orchestra takes up both the instrumental and the vocal parts, while the actor makes just a visual display based on the text of the song. In this case, the actor does not enact the lyrics of the song word for word, but mainly uses the sāttvikäbhinaya for the expression of his own feelings in reaction to the text of the dhruva he hears. ${ }^{192}$

The practice of joining a bodily enactment with a text that is not delivered directly by a character and is accompanied by music triggers legitimate doubts about where to set the border between theatre and dance, at a time when new types of intermedial performance ${ }^{193}$ were gaining visibility in the disciplinary discourse embedded in the śästra. ${ }^{194}$ Although the nātyāyita described above is typically regarded as a device in theatrical performances, where it is used, for instance, in combination with the lāsyāngas to communicate meaning in a more poignant and emphatic way, what exactly prevents us from considering it a kind of dance? And what prevents us from applying the definition of the nātyāyita to other kinds of solo performances, in which the performer does not speak but nevertheless executes bodily gestures at the same time that a text is rendered by a vocalist, to the accompaniment of instrumental music executed by an orchestras? And what happens when such a performance becomes the main focus, i.e. when a solo performance is executed by an actor/dancer independently of a dramatic performance? And what if the music in it, carrying its own narrative plot, becomes the main medium in the delivery of the poetic text? How can we distinguish such performances from, say, a one-actor monologue play like the Bhạna, classically listed as a dramatic genre? Does the only difference lie in the fact that the text is sung by a vocalist in the first case, while it is recited by an actor in the second?

All of these figures have been carefully analysed in the long passage edited in this book, where Abhinavagupta seeks to distinguish the new performance genres, such as danced or sung poetry (nrtta-kārya and rāga-kārya), from theatre proper $(n \bar{a} t y a)$ while taking into account the specific interaction of the bodily and the verbal media in both. As hinted above, this was achieved through the reinterpretation of the term abhinaya in the particular sense of

\footnotetext{
192 For a definition of the dhruvā defined as a nātyāyita, see Translation, 1.5.1, n. 26, and for a discussion of its enactment, see Translation, 6.5.3-4, n. 182 and n. 185.

193 I borrow the notion of intermediality from the theory of narratology, where forms of dance and theatre are nowadays analysed in terms of intermedial performances, i.e. performances that combine several media-here dance, prosody, music - that interact with verbal narratives. For an approach to the study of ancient Greek drama using narratological insights, see Gianvittorio-Ungar 2020.

194 On the new genres and on the verge between dance and theatre and their classifications in the technical texts, see Chapter 2, especially, § 2.1.
} 
'dramatic mimesis', which allowed for singling out Sanskrit drama from other genres that are characterized by what I have designated elsewhere as forms of 'incomplete mimesis.'195

In the last part of this chapter, dealing with the aesthetics of dance, I would like to illustrate such an exegetical strategy by focusing on Abhinavagupta's analysis of the genre called Dombikā, cited as a case of nrttakārya ('danced poetry' or 'poetry based on dance'), a term implying the presence of a poetic text in which dance is nevertheless the overarching category. The Dombikā represents a particularly exemplary case of what I regard as an instance of metadance or 'dance-within-dance', where the representation of a second-degree dancer by a dance performer reveals an original theoretical reflection about narrativity and its media, unique in the whole of Indian literature. It moreover allows some insights into the practice, protocol, and audience reception of a genre which, albeit lost both in its textual and performative dimensions, appears to have enjoyed considerable popularity around the turn of the millennium in Kashmir. As I shall demonstrate, the Dombikā as a performance genre described by Abhinavagupta must have been a sort of parody of another worldly - in the sense of non-fictional-dance performed by a dombikā, a lowcaste dancer. The dance of the dombika becomes the second-degree dance, the object represented in the genre that goes by the same name, Dombikā. ${ }^{196}$ An instance of what I consider the worldly counterpart of the Dombikā-the latter standing for a genre recorded in the dramatic treatises-has been described in Kalhana's twelfth-century Rājataranginī. We shall have a look at it shortly, after a review of scholarly opinions about the Dombikā.

In his masterful study of the Śrngāraprakāśa — an early eleventh-century treatise on poetry and drama contemporaneous with but unknown to Abhinavagupta-V. Raghavan (1978) remarks the absence of a definition of the Dombikā among the twelve minor genres, or padārthābhinayātmaka-prekșyaprabandha ('compositions to be seen, based on the enactment of the word meanings'), listed by Bhoja. He instead notes the mention of a genre called Dombalikā and the definition of another genre by the name Durmilitā, also appearing with the spelling Durmilikā. A reference to Dombalikā is also made in the tenth chapter of the Śringāraprakāsa, along with Prasthāna, where both are identified as performance genres ( preksya) realized through bodily enactment and devoid of other means of representation, such as the vocal. On the

\footnotetext{
195 See Ganser 2020.

196 To avoid possible confusion I visually distinguish, here and in the translation, Dombikā as a performance genre and dombika as the performer/danseuse.
} 
Durmilitā/Durmilikā, Raghavan (1978: 549, n. 1) quotes the opinion of Bhaya$\mathrm{ni}$, according to whom the name of the genre would be a Sanskritization of Dombalikā-appearing also as dombilī|dombilikā in narrative sources in Prakrit — and both would correspond to the Dombikā referred to several times in the Abhinavabhäratī (Bhayani 1993: 27-28). As we have seen, this form was already known to Dhanika, who mentions it by the name Dombī in his list of the nrtya types in the Avaloka. Abhinavagupta is the first to provide a definition for the Dombikā, which he borrows from some earlier, unidentified source attributed to some equally unidentified 'ancients'. ${ }^{197}$ A later treatise, Saaradātanaya's Bhāvaprakāśana (first half of the 13th c.), lists the Dombī and the Durmallikā (a variant of Durmilitā/Durmilikā) as separate genres complete with their own definitions. ${ }^{198}$ As noted by Bhayani, the definition of the Durmilita given by Bhoja looks very similar to the definition and the descriptions of the Dombikā in the Abhinavabhäratī, such that both can be traced to a single genre, common to earlier Jain sources. ${ }^{199}$

The definition of the Dombikā by Abhinavagupta reads:

When the mind of the king is seduced by words full of concealed passion, that graceful [genre] is known as Dombikā. ${ }^{200}$

And that of the Durmilitā by Bhoja:

The female messenger secretly betrays a clandestine affair or presents a description, through vulgar stories, of the passion between two young people. She, who belongs to a lower caste, dispenses counselling on that matter and begs for goods, and as soon as she has received [them] she longs to receive [more]. [When such is the content of the performance, the genre] is called Durmilitā. ${ }^{201}$

197 On the 'ancients', see § 1.4.1, n. 123, Translation, n. 3 o.

198 According to Cox (2016: 57-9o), the Bhāvaprakāśana is indebted to the Daśarūpaka and Avaloka, the Śrngāraprakāśa, and the Abhinavabhāratī.

199 Leclère (2013: 69-70) traces the genre to the lists contained in Jain narratives as early as the eighth century, spelled variously as dombilaya, dombilliya, dombilaga, and dumbadaa.

200 ABh ad Nś 4.268cd-269ab, vol. 1, p. 179, see Edition and Translation 8.5.2.

201 ŚP 11, p. 466: cauryapratibhedam yunor anurāgavarṇanam vāpi || yatra grāmyakathābhị kurute kila dūtikā rahasi |mantrayatica tadvișayam nyagjātitvenayācate ca vasu || labdhvāpi labdhum icchati durmilitā nāma sā bhavati | 
Apart from such inevitably concise definitions of the genre, the only textual passage containing some more details about the Dombikā is the fourth chapter of the Abhinavabhäratī. Here, Abhinavagupta provides information about the Dombikā on several occasions, especially, but not exclusively, in the passage edited in this book. He even quotes two Dombikās by name, the Cüdâmani ('The Crest Jewel') and the Gunamālā ('The Garland of Qualities'), and possibly the name of two Dombikā composers, the poets and masters Rānaka/Raṇaka and Guñjiyaka. ${ }^{202}$ In his article on the Dombikā and Șidgaka genres, Bhayani identifies four quotations from the scripts of Dombikās in the Abhinavabhāra$t \bar{\imath}$ : three are from the Dombikā called Cüd̂amaṇi, and one from the Gunamālā. Despite the ill-preserved state of these quotations, Bhayani's reconstructionsbased on the less corrupt text of the Kāryānuśāsana (in particular, on Hemacandra's sub-commentary, the Viveka) — highlight their linguistic and metrical form. The language is Apabhramśa, or Prakrit in the sole case of the third quotation from the Cüdāmaṇi, and the metre is rāsaka for the portions in Apabhramśa and $g \bar{a} t h \bar{a}$ for the one in Prakrit. ${ }^{203}$ From the descriptions of Abhinavagupta, it is clear that these verses were set to music and delivered through song. Another quotation in Sanskrit-unrecorded by Bhayani and Raghavan but most probably also part of the Gunamā $l \bar{a}$ — suggests that the Dombikā was a multilingual genre that followed its own conventions. ${ }^{204}$

In the Dombikā, Raghavan saw an antecedent of the Nautch, since he believed that its songs were rendered vocally by the accompanying vocalists while a dancer or dombi interpreted them through her dance. However, the

202 See ABh ad NŚ 4.280, vol. 1, p. 186: ata evaitatsthānopajōvibhir eva śrīrānakāädikavibhir dombikādau caturapasārakah prayogạ̣ and ABh ad Nś 4.318cd-319ab, vol. 1, p. 203: raṇakaguñjiyakādeś caturapasārakādividhā ca dọbikādișu krameṇa nartakìvrddhir ācāryair $\bar{a} d h e y \bar{a}$. The indication that Śrirānaka/Raṇaka is a kavi points to his being a composer of the text of a Dombikā. The title ācārya in the second quotation might indicate that such figures were both text composers and theatre or dance masters, which is also suggested by the content of both quotations, namely the increase in the number of dancers in a Dombikā to four, and their entering and exiting the stage in succession, just as in the songs of the pürvaranga.

203 According to Warder (1972: 157), who adduces a reference from the Abhinavabhäratī, the text of the Dombikā was, like that of the Prasthāna, composed in Saindhava, a type of Apabhramśa originally from Sindhu. Bhayani states that the other uparūpakas also used Apabhramśa and rāsaka metre, namely the Rāsaka and Nāṭyarāsaka (also known as $c a-$ rcarī), since some literary works of the same name exhibit these very characteristics. He concludes: 'This evidence for the use of Apabhramśa for some of the Uparūpakas significantly extends the hitherto known range of Apabhramśa literature' (Bhayani 1993: 26).

204 A passage with both Apabhramśa and Sanskrit words is quoted in connection with the Gunamālā in ABh ad Nś 4.263cd, vol. 1, p. 173, on which see Translation 6.4.4, n. 15 o and $15^{2}$. 
dancer in the Dombikā did not render the words and meaning closely through abhinaya, but concentrated mainly on bodily movements and expressions similar to everyday ones, whereas in the Nautch the padams (lyrical compositions) are generally rendered word for word. Raghavan attributes this difference to the popular character and origin of the genre called Dombikā. He derives this idea from the description, in Kalhana's Räjataranginin, of a musical and dance performance by an ensemble composed of a domba singer (dombagāyana) and his two daughters, also domba singers (dombagāyika ), collectively referred to as a domba ensemble (dombamandala). Raghavan further mentions the existence of a peripatetic community of performers in South India called dombas, whose performances, the dombankütțädis, featured acrobatic numbers, drumming and rope-dancing (Raghavan 1993: 190-191). Räjataranginī 5·354-380 recounts the visit of a troupe of dombas to the court of Kashmir in the tenth century, and how the ruling king Cakravarman, flattered and seduced by the singing and dancing of the two daughters of Ranga, the domba singer, introduced them into his court. Blinded by passion, Cakravarman let the dombas take control over the affairs of his kingdom, while he fell into misery and was eventually murdered. ${ }^{205}$

Such commonalities led Raghavan and Warder to consider the Dombikā described by Abhinavagupta on a par with the performance by the dombamandala described in the Räjataranginī. The differences between the two, however, were not properly taken into account, so the nature of the Dombikā as a genre has generally been misconstrued. Looking at the occurrences of forms similar to 'domb' in the Prakrit sources, Bhayani concludes that the dombi or domba girl must have been the central figure of this genre, giving its name to it (Bhayani 1993: 28). According to Bose (2007: 123), the Dombikā is 'a minor dramatic form which shows how a woman performs the actions of flattering a king'. Although these statements seem to suggest that the dombi, or a comparable figure carrying out the seduction of the king, was the main character of the Dombikā, the failure to make a distinction between the dombi $/$ dombika as a performer or as a character has led scholars to identify these two figures. Because of this confusion, scholars have tended to consider the genre called Dombikā as a lower one, since it was thought to be performed by a dombī, a low-caste dancer, in order to flatter a king and obtain material gain, just as the two singers in the episode recorded in the Räjataranginī. ${ }^{206}$

205 See also Warder 1972: 156-157. For reference to dombas in Dharmaśāstra literature, see Kane 1930: 82.

206 Raghavan (1993: 190) compares the theme of the Dombikā, i.e. love affairs, in particular clandestine ones, with the theme of the 'lower specimens of padas in bharata nätya'. Obvi- 
In my opinion, the dombi as a danseuse of a lower form of spectacle, especially aimed at entertaining the king in a courtly context, is just a 'fictional character' of the Dombikā as a genre of danced poetry described in the dramatic sources. If this interpretation is correct, the genre called Ḍombikā should have been analysed at great length by Abhinavagupta as an instance of narrative dance, to be carefully distinguished from theatre, not only because it displays a complex structure, in which parts of abstract dance alternate with songs and abhinaya, but because the status of the performer (the interpreter) and that of the character (the interpreted) are particularly difficult to grasp in this genre. Let us have a closer look at the protocol of performance in a Dombikā as described in the Abhinavabhäratī. I will attempt to separate the different phases by numbering them, in what I regard as a possible reconstruction of this lost genre. I will then contrast these data with the descriptions of this performance in the Räjataranginī. Finally, I will address the theoretical problems raised by this genre in Abhinavagupta's reformulation of abhinaya as a specific mode of dramatic mimesis that cannot be extended to the art of dancing.

The protocol of performance in a Dombikā can tentatively be reconstructed as follows: ${ }^{207}$ 1. gita: invocatory song rendered by the vocalists, entrance of the dancer; 2. pratijña a : announcement of the Dombikā and its theme; 3 . varnana-gita: storytelling by the dombikā with different embedded characters, in the form of a sung text; 4 . samuddeśa: address to the king or patron; 5. anyat ceștitam: telling of another story; 6. upasamhāara: conclusion by the dombikā; 7 . sābhinayanrtta; 8. śuddhanrttta.

Although there may have been some variability, and some of the descriptions might well reflect just one particular instance among the existing Dombikās, it emerges from the sparse references in the fourth chapter that the main portion of the Dombikā was narrative and to some degree fictional, and that this was framed by an initial invocation and some further dancing performed by the dancer without interpreting any character, to the accompaniment of the orchestra. The main part featured the character of the dombika proper, a dancer

ously enough, this judgement rests on the bias against Indian dance as a degraded and vulgar practice at the beginning of the twentieth century (cf. my remarks in §1.2).

207 All the passages dealing with the Dombikā are extremely corrupt and difficult to restore to some degree, since the only manuscripts that preserve those passages are $D, M_{1}$, and $T_{1}$, which provide the same readings most of the time. Unfortunately, $\mathrm{T}_{4}$ skips all the relevant passages. In this respect, the KAV has proved an invaluable tool for instituting some better readings or confirming some conjectural emendations. The secondary literature on the subject does not help either. On the descriptions of the Dombikā in the technical literature, see Raghavan 1978 and Bose 2001. 
who seduces the king to obtain material benefits. This part corresponds to the main content of the Dombikā as a genre endowed with a poetic script (a kārya), and is itself divided into several phases alternating singing and dancing, also including narrative portions aimed at displaying embedded characters within a plot of clandestine love (phases 3-6). The second part of the performance consisted in dance without any depiction of secondary characters, in which songs and instrumental music were performed together with dance, alternating phases of pure movement and phases including some kind of abhinaya. In this part, multiple dancers possibly performed together (phases 7-8).

The performance by the Domba party described in the Rājataranginī shows some similarities: it is mainly presented as a musical performance, with a main vocalist, and two female singers. The female performers sing and accompany their singing with coquettish bodily gestures, by means of which they seduce the king. As they notice his feelings, they sing tenderly with smiles, exchanging glances with him. At the end, the king gives jewels to the domba party and retires. The domba singer designates the king with some epithets and allusions and by name during a violent tändava. The narrative of the seduction of the king by the performer through singing, facial expressions, and bodily gestures is thus analogous in both descriptions, and similar to the singing by the women who play the role of seducers, alternating with that of a male vocalist. The manner of addressing the king with flattering words is also a common feature. In the account of the Räjatarangini, however, no mention is made of either a narrative text underlying the singing or an enactment of the meanings of the song, whereas by contrast the Dombikā is presented as a nrttakārya, a name that emphasizes dance as the main performative medium, joined with a poetic text delivered by the dancer or by the vocalist with musical accompaniment. My suggestion is that the Dombikā as a danced genre is profoundly different from the performance described in the Rajjatarainginī, and represents a sort of parody of it.

Abhinavagupta takes in fact great pains to draw a distinction between the worldly dancer, who has arrived in order to dance and engage in performing the genre called Dombikā, and the dombikā as a 'fictional character' in that firstdegree performance. The second-degree or embedded performance, of which the dombika character is the second-degree performer, aims at charming the king with stories about furtive love. The vocabulary used by Abhinavagupta to describe these narrative parts suggests that these stories and their embedded characters were not enacted by the dombika dancer in a gestural pantomime, but rather that they were rendered through vocal narrative or songs. Typically, the verb used to speak of her activity in such a narrative part is abhidhā('to speak', 'to denote'), not abhini- ('to enact'). Even when the dancer displays 
some gestures, she is just showing (pradarś- 'to show') or making a display (darśanamātra ${ }^{\circ}$ ) of how a dombikā dances, with or without abhinaya. Again, the dancer is said to perform in a way similar (sadrś-) to how the real dombika performed in the past, which is marked by Abhinavagupta through the opposition prayunkte (present 'performs', for the performer of the Dombikā)/prāyunkta (imperfect 'performed', for the dombikā). The dancer, however, does not enact the dombika as if she were directly present in front of the spectators, since she does not conceal her own self with the costume of the dombika . Moreover, her dialogues are sometimes rendered by the vocalist and only punctuated by some coquettish gestures, which violates the basic coordination of words and gestures prescribed for the harmonious acting. ${ }^{208}$ Abhinavagupta's choice of words to refer to the pseudo-enactment in a Dombikā indeed emphasizes the relation of similarity between the performer and the character, which typically defines imitation-qua-mimicry, and hence also parody. As shown above, imitation was exactly what Abhinavagupta wanted to ban from theatre in general and from dramatic acting in particular, in the reconfigured sense of 'quasidirect perception'. This amounts to saying that in a Dombikā, as in all genres of narrative dance, there is no abhinaya in the fullest sense, since the quasidirect experience that is definitional of theatre is lacking.

Dance can indeed combine with a poetic text and have a narrative content, but even if the quality of its movements conforms to its basic flavour, it cannot give rise to that particularly vivid experience of the characters and emotions proper to theatre, in which the confusion between performer and character is a necessary prelude to the generalization of the emotion that alone can lead a spectator to give the consent of the heart and identify with the emotional situation depicted. ${ }^{209}$ Although the phases of the aesthetic process leading to the savouring of rasa are not a direct topic of discussion in the analysis of narrative dance, the lack of a quasi-direct perception of a character is linked by Abhinavagupta with the theme of instruction and pleasure as the twofold purpose of theatre. In the Dombikā, it is said, instruction is not the primary aim, nor is pleasure. Although the activity of the dancer is directed at pleasing the king, this nevertheless applies to the worldly activity of the dombika, while the genre, like all other danced genres, ultimately aims at satisfying the deities. Instruction, in its turn, can be derived indirectly from the manifestation of the extraordinary characters evoked in the narrative parts. This is indeed a charac-

208 On the necessary dependence of one's gestures on one's speech, see my remarks, at the beginning of this section, on the diachronic yet interdependent use of gestures and sentences in the various phases of the śärírasāmānyābhinaya.

209 On the successive steps in the aesthetic process, see n. 4 above. 
teristic of all genres of danced or sung poetry, in which the pedagogical ends are subordinated to the pleasurable nature of the medium, and both of these to higher ritual ends. At the other end of the spectrum, Abhinavagupta evokes another class of texts that were publicly recited, thus in a way performed, corresponding to the Purānas, where the depiction of the good and evil deeds of men aims exclusively at instruction in the aims of mankind, without the pleasurable filter of poetic or theatrical embellishments and the persuasive force of the direct presence of the character. ${ }^{210}$

The incomplete mimesis that characterizes narrative dance is no anodyne detail, since it accounts for the very incommensurability of theatre and dance. It was perhaps the need to preserve Bharata's twofold division of the spectacular object, while at the same time accounting for the undeniable presence of narrative content in the newly recorded genres, that prompted the commentator's reflection on the specificity of representation and its media in theatre and other forms of performed narratives. The differentiation between different kinds of abhinaya - foregrounded by the recognition of a technical and a nontechnical sense of the word-became not only a strategy to explain narrative dance as a genre distinct from theatre, but also an expedient to account for all the passages in which Bharata spoke of abhinaya in the context of dance. How exactly the root abhin $\iota$ has to be understood in such cases is explained with reference to the dancer's enactment of the songs of the pürvaranga:

The expression 'after [paying homage to the deities] the [dancer should perform] the acting (abhinayam àcaret)' is to express the extraordinariness [of its object], through a visualization (bhāvanā of the meaning of that [song] by means of an abundant devotion (bhakti). The enactment (abhinaya) of the text of the āsāritā, which has as its object the meaning of words and sentences, is a conveying in front of one's own self (svātmany $\bar{a}$ bhimukhyanayanam), which does not aim at the spectators. ${ }^{211}$

This passage assigns a specific value to the preverb abhi-, so that abhinaya comes to mean 'conveying in front of one's self', possibly through a visualiza-

210 See Translation 6.6.5, n. 202. For an in-depth study of the public reading, narration, and performance of the Purānas, in particular the Bhägavatapurāna, until the present day, see Taylor 2016.

211 ABh ad Nś 4.276ab, vol. 1, p. 184: tato 'bhinayam iti. bhaktyatiśayena tadarthabhāvanayā viśiștatāạn $\left[\mathrm{M}_{1} \mathrm{~T}_{1} \mathrm{E}_{1(1)} \mathrm{E}_{1(2)} \mathrm{E}_{2}\right.$, viśișțavișayatāọ $\left.\mathrm{T}_{4} \mathrm{E}_{1(4)}\right]$ pradarśayitum. āsāritavākyasya padārthavākyārthavișayo 'bhinayah svātmany ābhimukhyanayanam $\left[\mathrm{T}_{4} \mathrm{E}_{2}, \bar{b}\right.$ bhimukhyanayanāt $\left.\Sigma_{\mathrm{M}} \mathrm{E}_{1}\right]$. na tu sāmājikān prati. See also Translation 7.2.2 on the secondary meaning of abhinaya in connection with the songs of the pürvarainga. 
tion $($ bhāvana $)$ of the deity described by the song, which assumes the character of a meditation by the artist filled with devotion. In the primarily ritual part of the performance that is the pürvaranga, in fact, the various songs are meant to praise and satisfy the deities. Another secondary use of the word abhinaya is that of storytelling, in which the story is rendered through speech and gestures, although the body movements just adequate to the song's content and rhythm. ${ }^{212}$ These examples suggest that there existed a number of forms that used a blend of several media, in particular vocal speech and bodily gestures, combined with musical accompaniment, to bring out verbal content. Based on their characteristics, these forms were regarded as either literary or performative by Indian theoreticians. However, all of them were ultimately found to be different from theatre, lacking as they were that specific kind of embodiment that can be assured only in the case of an actor putting on the costume of a character and rendering the dialogues with the appropriate linguistic code and accompanying movements.

212 See Translation 7.2.3. 